\title{
A Mysterious World Revealed: Larval-Adult Matching of Deep-Sea Shrimps from the Gulf of Mexico
}

\author{
Carlos Varela * and Heather Bracken-Grissom (D) \\ Institute of Environment, Department of Biological Sciences, Florida International University, \\ North Miami, FL 33181, USA; hbracken@fiu.edu \\ * Correspondence: cvare015@fiu.edu
}

\begin{abstract}
The identification of deep-sea $(>200 \mathrm{~m})$ pelagic larvae is extremely challenging due to the morphological diversity across ontogeny and duration of larval phases. Within Decapoda, developmental stages often differ conspicuously from their adult form, representing a bizarre and mysterious world still left to be discovered. The difficulties with sampling and rearing deep-sea larvae, combined with the lack of taxonomic expertise, argues for the use of molecular methods to aid in identification. Here, we use DNA barcoding combined with morphological methods, to match larval stages with their adult counterpart from the northern Gulf of Mexico and adjacent waters. For DNA barcoding, we targeted the mitochondrial ribosomal large subunit 16S (16S) and the protein coding cytochrome oxidase subunit 1 (COI). These data were combined with previous sequences to generate phylogenetic trees that were used to identify 12 unknown larval and two juvenile species from the infraorder Caridea and the suborder Dendrobranchiata. Once identified, we provide taxonomic descriptions and illustrations alongside the current state of knowledge for all families. For many groups, larval descriptions are missing or non-existent, so this study represents a first step of many to advance deep-sea larval diversity.
\end{abstract}

Keywords: DNA barcoding; Gulf of Mexico; Caridea; Dendrobranchiata; Decapoda; larval-adult matching; life history

457. https://doi.org/10.3390/

d13100457

Academic Editors: Michael Wink,

Patricia Briones-Fourzán and Michel

E. Hendrickx

Received: 16 August 2021

Accepted: 15 September 2021

Published: 23 September 2021

Publisher's Note: MDPI stays neutral with regard to jurisdictional claims in published maps and institutional affiliations.

\section{Introduction}

In order to understand the evolution, distribution and ecology of marine organisms, as well as their impact on community and ecosystem processes, it is important to study their life history and developmental biology [1-3]. Decapod crustaceans, including shrimps, lobsters and crabs and are well-known due to their economic importance in the food, aquarium and pharmaceutical industries [4,5]. However, much less is known about their often-complex life histories. Decapods have numerous reproductive strategies, and those with sexual reproduction produce eggs which are either deposited directly in the bottom of the sea floor, remain attached to the parents, or are released as free moving organisms into the pelagic environment [6]. Many species progress through a series of larval stages (i.e., nauplius, mysis, zoea, phyllosoma), often representing bizarre forms unidentifiable from their adult counterpart [7] (Figures 1 and 2). The duration of the larval stages varies between and within taxonomic groups, sometimes lasting several months before settling as juveniles or benthic adults [8-11]. Due to the morphological disparity across ontogeny and duration of larval phases, the identification of planktonic decapod larvae, especially those in the deep sea $(>200 \mathrm{~m})$, is extremely challenging.

Descriptions of decapod larval stages are limited, with most of the preexisting literature focused on shallow-water species of economic interest because of their food and/or ornamental value [12-14]. For example, in the Gulf of Mexico, larvae stages are known from the shrimp family Penaeidae [15-17], the crab families Menippidae (stone crabs) and Portunidae (swimming crabs) [18-21] and the spiny lobster family Palinuridae [22]. In the 
last decade, additional papers have been published for decapod larval stages in the Gulf of Mexico [23-25], however more studies are needed.

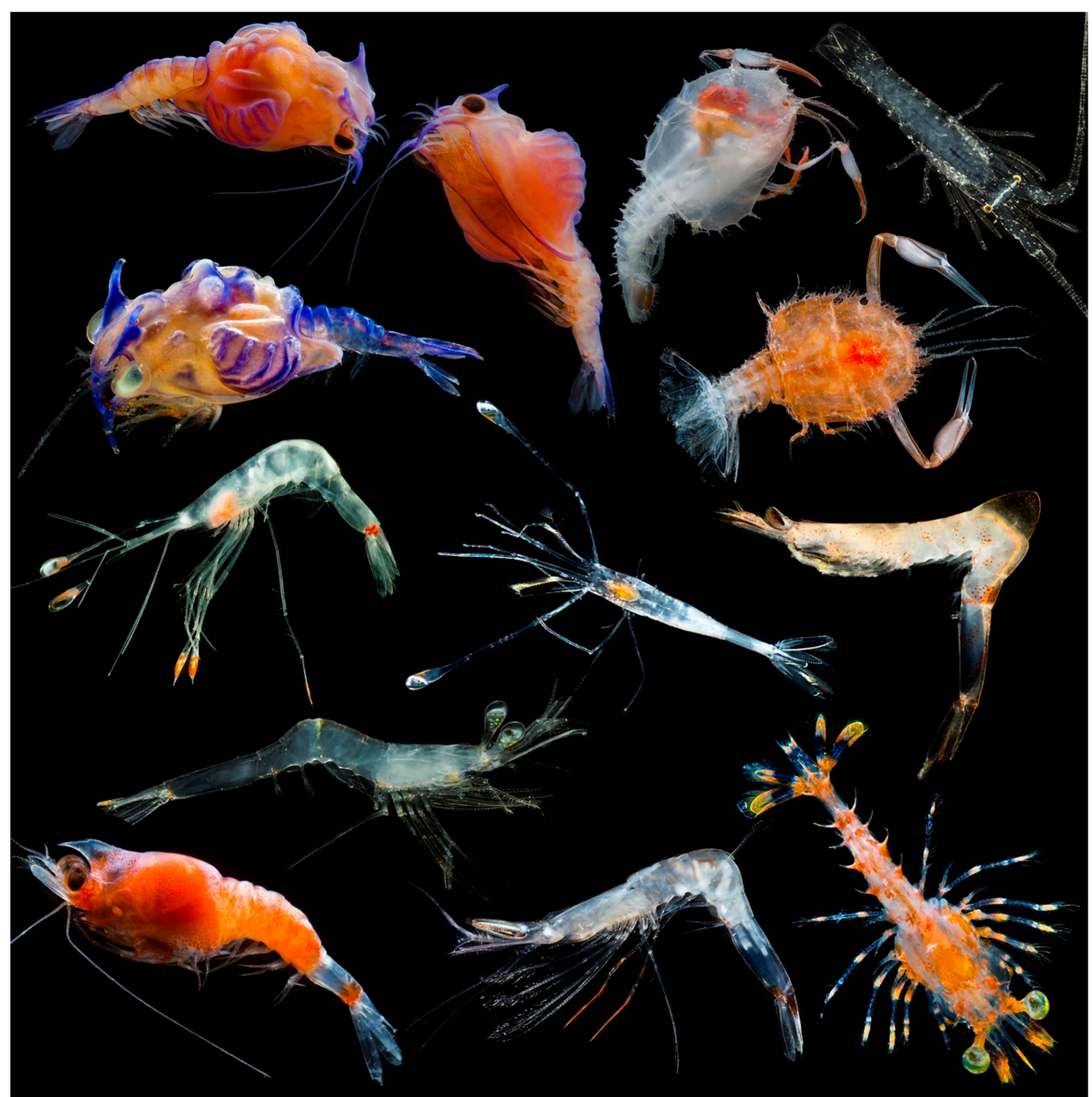

Figure 1. Examples of shrimp and lobster developmental stages collected on deep-pelagic research cruises in the northern Gulf of Mexico. CDantéFenolio DEEPENDI RESTORE.

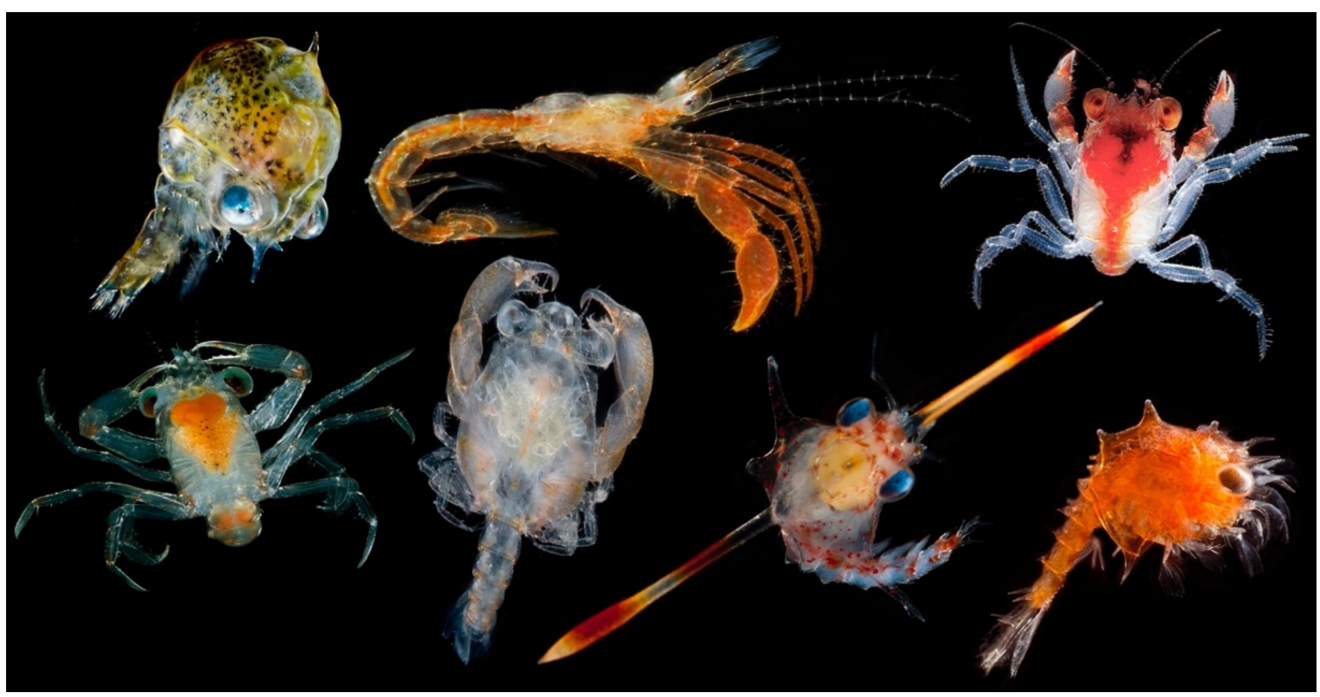

Figure 2. Examples of crab developmental stages collected on deep-pelagic research cruises in the northern Gulf of Mexico. CDantéFenolio DEEPEND I RESTORE.

Our knowledge of pelagic or benthic deep-sea decapod larvae is inadequate or even non-existent and is further complicated by the technological demands and expense of 
sampling in deep oceanic waters. Extensive knowledge of taxonomy is required to achieve reliable larval identifications, and because this requires specialized training and years of practice, most researchers have difficulty recognizing larval stages in a plankton sample [26,27], especially those in the deep sea [28]. Those that have been identified come from larval-rearing experiments of females, and because males and females differ dramatically in larval morphology, several have been incorrectly identified [26,29]. Another factor that complicates identification is that the literature can be very old and difficult to access $[7,29]$, however adequate library resources can aleviate this problem. Due to the abovementioned reasons, illustrated guides (based on external morphological characters that can be observed under a stereomicroscope) are necessary to aid future investigations and identifications, especially for those with limited taxonomic training.

Morphological descriptions can be given alongside molecular methods (DNA barcoding) to fully characterize and document larval-adult linkages. DNA barcoding is a molecular method for fast and accurate species identification and can be particularly useful in early life stages that differ conspicuously from their adult form [30,31]. Although rearing experiments have facilitated the taxonomic identification of larvae from plankton samples, most are difficult (or impossible) to breed and maintain in the laboratory. Molecular approaches, such as DNA barcoding, can be an excellent alternative or complementary method for larval identifications [32-35]. This method does require a reliable database of adult barcodes that are linked to vouchered museum specimens in zoological collections. When these adult datasets are available, larvae can be targeted from similar localities (or a species distributional range) and matched back to adults using DNA barcoding genes (ex. $16 \mathrm{~S}$ and COI) and phylogenetic trees. A very recent barcoding study on adult deep-pelagic crustaceans was conducted in the Gulf of Mexico and adjacent waters [35], and we plan to use this dataset (alongside previously published datasets) to match unknown larvae collected on research expeditions into the northern Gulf of Mexico and adjacent waters over the past 5 years.

Adult-larval linkages are critical because they can enhance our basic biological understanding of the species under study. First, documenting and describing larval stages allows for the correct identification of a species during development. The correct identification of a species is arguably the most important first step to any scientific investigation. Secondly, larval-adult linkages have allowed for the description of complex life cycles and distributional ranges for many species [36-38]. An example is the deep-sea shrimp, Cerataspis monstrosus Gray, 1828, which can be found in the abyssal plains (up to $5000 \mathrm{~m}$ in the Gulf of Mexico) but has a larval form (Cerataspis-"monster" larvae) found in the mesopelagic $(\sim 500 \mathrm{~m})$ [39]. Lastly, the correct identification and distribution of larvae is critical to understanding the food web dynamics in the Gulf of Mexico, as crustacean larvae are often the main food source for small and large migratory fishes, cephalopods and some marine mammals [40-43]. Overall, these adult-larval linkages do not only allow for advancements in taxonomy and systematics, but also provide fundamental information for studies in ecology and evolution.

In this paper we will use a molecular technique, namely DNA barcoding, to match early-life stages with their adult counterpart in an effort to better understand the life history and distribution of deep-sea ( 200-1500 m) decapod crustaceans from the northern Gulf of Mexico and adjacent waters. We provide larval-adult matching for 14 species (12 larval, 2 juvenile) based on DNA barcoding and phylogenetic methods. For each species, detailed morphological illustrations and taxonomic descriptions of diagnostic characters are provided. Of the 14 species in this paper, only four have some previous larval knowledge: Heterocarpus ensifer, of which only the early four zoeal stages are known [44,45], Plesionika edwardsii, of which the seven first zoea stages are known [46], Funchalia villosa, of which some taxonomic data on its postlarva is known [47] and Cerataspis monstrosus of which some of the mysis stages are known [48]. We hope this research can guide future studies and aid in the identification of deep-sea crustacean larvae from the Gulf of Mexico. 


\section{Materials and Methods}

\subsection{Sample Collection}

All material used in this study was collected during eight research expeditions totaling $\sim 126$ days at sea (Supplementary Table S1). Six of the eight research cruises were in the Gulf of Mexico on the R/V Point Sur as part of the Deep Pelagic Nekton Dynamics of the Gulf of Mexico (DEEPEND) consortium (http:/ / www.deependconsortium.org, accessed on 14 September 2021). The other two cruises were in the Florida Straits on the R/V Walton Smith as part of a National Science Foundation grant to study bioluminescence and vision in the deep sea. During the DEEPEND cruises, every collection site was sampled during the day (entire water column from the surface to $1500 \mathrm{~m}$ depth, sampled at noon) and at night (surface to $1500 \mathrm{~m}$ depth, sampled at midnight). Sampling occurred during the wet (August) and dry (May) seasons from 2015 to 2016 and one during the dry (May) season from 2017-2018. Gulf of Mexico samples were collected with a Multiple Opening/Closing Net and Environmental Sensing System (MOC-10) composed of six $3 \mathrm{~mm}$ mesh nets, allowing for collected specimens to be assigned to a depth bin $(0-200 \mathrm{~m}, 200-600 \mathrm{~m}$, 600-1000 m, 1000-1200 m, and 1200-1500 m; the sixth net sampled from 0 to $1500 \mathrm{~m}$ ). Samples from all nets and depths were included as part of this study. More details on DEEPEND net sampling and methods can be found in [49]. Florida Straits samples were collected with a $9 \mathrm{~m}^{2}$. Tucker trawl fitted with a cod-end capable of closure at depth (for details see [50]), allowing for discrete depth sampling. All sampling was conducted in the midwater, from $0-800 \mathrm{~m}$.

The contents of each net were placed in a large tray and crustacean larvae were sorted and preserved as whole-specimens, either in $80 \% \mathrm{EtOH}$ or an RNA-stabilizing buffer (RNAlater) and stored at $-20{ }^{\circ} \mathrm{C}$ onboard the vessel. Upon returning samples to the $\mathrm{lab}$, all batch-stored individuals were transferred to the Florida International Crustacean Collection (FICC). All individuals selected for DNA barcoding were then given a unique voucher ID in the FICC database, including all relevant collection metadata. Metadata included collection date, time (day or night), collection locality and GPS coordinates, and depth. The unique voucher number ensured that the resulting DNA barcode matches to one and only one individual. Total genomic DNA was extracted from muscle tissue of the abdomen or the 3rd to 5 th pleopod. Tissue collected from each vouchered specimen was stored in $80 \% \mathrm{EtOH}$ at $-20{ }^{\circ} \mathrm{C}$ and voucher specimens were preserved in $80 \% \mathrm{EtOH}$ and deposited in the FICC.

We adopt the terminology of [51] for Dendrobranchiata and [52] for Caridea, to standardize the different life stages. The number of specimens examined per stage $(\mathrm{N})$ is referred in each description. Measurements taken were Carapace length (CL), measured from the tip of rostrum to the posterior margin of the carapace and Total length (TL), corresponding to the distance from the tip of the rostrum to the posterior end of telson.

\subsection{Molecular Analyses}

\subsubsection{DNA Extraction, PCR and Sequencing}

Total genomic DNA (gDNA) was extracted from muscle tissue of the abdomen or the 3rd to 5th pleopod using DNeasy ${ }^{\circledR}$ Blood and Tissue Kits (Qiagen, Valencia, CA, USA). When the tissue did not completely digest, $10 \mu \mathrm{L}$ of $10 \%$ DTT and an additional $10 \mu \mathrm{L}$ Proteinase $\mathrm{K}$ were added, and samples were incubated until complete digestion was achieved. Visualization of total genomic DNA was performed using $2 \%$ agarose gels, run at $100 \mathrm{~V}$ for $90 \mathrm{~min}$, and the DNA concentration was measured using a dsDNA HS Assay kit on the Qubit 2.0 Fluorometer (Invitrogen, Life Technologies, Carlsbad, CA, USA).

Two partial mitochondrial genes were selected due to their informativeness in decapod barcoding studies. These included the partial $16 \mathrm{~S}$ large ribosomal subunit and cytochrome oxidase I (COI) gene, totalling $\sim 50$ basepairs (bps) and $~ 600 \mathrm{bps}$, respectively. All primers included M13 tails as a universal tag (Invitrogen, Carlsbad, CA, USA) (Table 1). 
Table 1. The targeted genes, primer sequences and annealing temperatures used in this study.

\begin{tabular}{|c|c|c|c|}
\hline Targeted Gene & Forward Primer & Reverse Primer & Anneal Temperature \\
\hline \multirow[t]{2}{*}{$16 \mathrm{~S}$} & $\begin{array}{l}\text { 5'-TGCCTGTTTATCAAAAACAT-3' } \\
\text { 5'-CGCCTGTTTATCAAAAACAT-3' }^{\prime} \\
\text { [53] }\end{array}$ & $\begin{array}{l}\text { 5'-AGATAGAAACCAACCTGG-3' } \\
\text { [54] }\end{array}$ & $45^{\circ} \mathrm{C}$ \\
\hline & $\begin{array}{l}\text { 5'-CGCCTGTTTAACAAAAACAT-3' } \\
\text { [55] }\end{array}$ & $\begin{array}{l}\text { 5'-CCGGTCTGAACTCAGATCACGT-3' } \\
\text { [55] }\end{array}$ & $45^{\circ} \mathrm{C}$ \\
\hline \multirow[t]{2}{*}{$\mathrm{COI}$} & $\begin{array}{l}\text { 5'-GGTCAACAAATCACAAAGATATTG-3' } \\
{[56]}\end{array}$ & $\begin{array}{l}\text { 5'-TAAACTTCAGGGTGACCAAAAAATCA-'3 } \\
{[56]}\end{array}$ & $40{ }^{\circ} \mathrm{C}$ \\
\hline & $\begin{array}{l}5^{\prime} \text {-YCAYAARGAYATTGG-3' } \\
\text { [35] }\end{array}$ & $\begin{array}{l}\text { 5'-GGRTGNCCRAARAAYCA-3' } \\
\text { [35] }\end{array}$ & $45^{\circ} \mathrm{C}$ \\
\hline
\end{tabular}

Polymerase chain reaction (PCR) using a thermal cycler (Pro-Flex PCR System) was used to amplify the $16 \mathrm{~S}$ and $\mathrm{COI}$ gene regions. Thermal profiles were as follows: initial denaturing for $2-5 \mathrm{~min}$ at $94{ }^{\circ} \mathrm{C}$; annealing for $35-40$ cycles: $30-45 \mathrm{~s}$ at $94 / 95^{\circ} \mathrm{C}$, $30 \mathrm{~s}$ at $38-50{ }^{\circ} \mathrm{C}$ (depending on the taxon and primers used; see Table 1 ), 1 min at $72{ }^{\circ} \mathrm{C}$; final extension 2-3 min at $72{ }^{\circ} \mathrm{C}$. Both forward and reverse strands were amplified, and all PCR products were sent to GENEWIZ (South Plainfield, NJ, USA) for sequencing. Consensus sequences were generated within Geneious 9.1.7 (Biomatters Ltd., Newark, NJ, USA) and primer regions and non-readable segments at the beginning of the sequences were manually removed prior to multiple sequence alignment. To check for pseudogenes, all six possible reading frames for the COI gene were translated to ensure stop codons were not present. On several occasions, several individuals of the same species were included to help identify contamination. All obtained sequences were deposited in the GenBank database (Supplementary Table S1).

\subsubsection{Phylogenetic Tree Construction}

Newly generated larval sequences were aligned with a subset of data generated in [35] alongside other sequences from previously published studies (Supplementary Table S1) to help identify the unknow larvae. The Multiple Sequence Alignment Tool (MAFFT) with the E-INS-i algorithm [57] was used to align the DNA sequences. ModelFinder [58] was used to determine the model of evolution that best fit each gene. Maximum Likelihood (ML) analyses were conducted using IQ_TREE 2.0.4 [59] and a search for the best-scoring tree with 1000 replicates [60] was performed. Ultrafast Bootstrapping (UFBoot) was used to assess confidence in the resulting topologies. Bayesian Inference (BI) analyses were performed using parameters identified by ModelFinder and conducted in MrBayes (v.3.2.6) [61]. Both single-gene trees (16S and COI) and concatenated trees $(16 \mathrm{~S}+\mathrm{COI})$ were constructed for each major group using ML and BI approaches. Trees were visualized in FigTree v.1.4.2 and topologies were compared across all phylogenies for congruence. All support values (UFBoot and posterior probabilities) are listed on the corresponding branch. High support is indicated by values $>95$.

\section{Results}

\subsection{Larval-Adult Identification using DNA-Barcoding}

Phylogenetic trees were constructed to help in identification and evolutionary relationships should not be inferred based on these findings. In total, 28 larval individuals were included in this study. Our DNA barcoding efforts resulted in a total of 25 de novo $16 \mathrm{~S}$ sequences and nine de novo COI sequences from these larvae. Using a subset of the dataset generated from [35] and previous studies, in combination with these newly generated larval sequences (Supplementary Table S1), the final tree (16S + COI) included 51 total species from the infraorder Caridea and suborder Dendrobranchiata (Figure 3). 


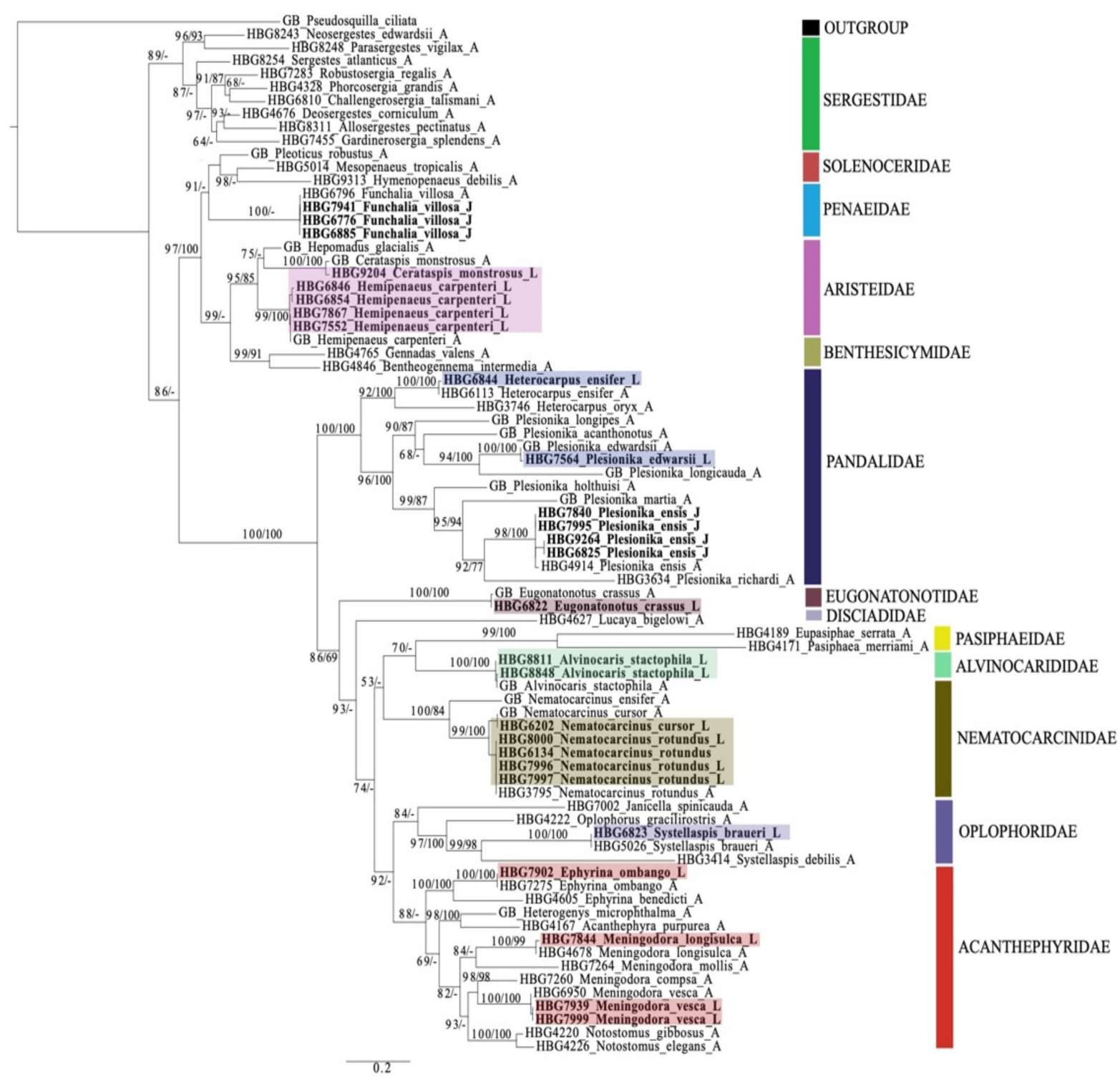

Figure 3. Maximum likelihood (ML) phylogeny of 51 barcoded individuals from the infraorder Caridea and suborder Dendrobranchiata based on the mitochondrial genes, 16S and COI. The number along the branches represent ultrafast bootstrap support (UFboot) values and Bayesian posterior probabilities (pp), respectively. UFBoot and pp values >95 indicate strong support. Voucher numbers (HBG\#) represent specimens in the Florida International Crustacean Collection (FICC) and GB represents GenBank sequences. Family names are listed along the vertical bars. A = adult representative, $\mathrm{J}=$ juvenile representative and $\mathrm{L}=$ larval representative. Highlighted individuals represent the larvae matched with their adult counterpart.

Using this phylogeny, we were able to successfully match 14 larval and juvenile species ( $=16$ developmental stages) with their adult counterparts. From the infraorder Caridea, the larvae represented six families, eight genera and eleven species. From the suborder Dendrobranchiata, the larvae represented two families, three genera and three species. The families of larval carideans identified included Acanthephyridae Spence Bate, 1888, Alvinocarididae Christoffersen, 1986, Eugonatonotidae Chace, 1937, Nematocarcinidae Smith, 1884, Pandalidae Haworth, 1825, and Oplophoridae Dana, 1852. The families of larval dendrobranchiates included Penaeidae and Aristeidae. Overall, the 14 larval and juvenile species that were successfully matched to their adult counterpart include Alvinocaris stactophila Williams, 1988, Eugonatonotus crassus (A. Milne-Edwards, 1881), Systellaspis debilis (A. Milne-Edwards, 1881), Nematocarcinus cursor A. Milne-Edwards, 1881, 
N. rotundus Crosnier and Forest, 1973 Plesionika edwarsii (J.F. Brandt in von Middendorf, 1851), P. ensis (A. Milne-Edwards, 1881), Heterocarpus ensifer A. Milne-Edwards, 1881, Meningodora vesca (Smith, 1886), M. longisulca Kikuchi, 1985 and Ephyrina ombango Crosnier and Forest, 1973 from Caridea and Funchalia villosa Bouvier, 1905, Hemipenaeus carpenteri Wood-Mason in Wood-Mason and Alcock, 1891 and Cerataspis monstrosus Gray, 1868 from Dendrobranchiata. Single-gene trees for $16 \mathrm{~S}$ and COI genes are provided as Supplementary Materials (Supplementary Figures S1 and S2).

\subsection{Larval Morphology}

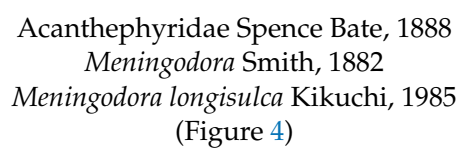

Material examined: Gulf of Mexico: HBG 7844, R/V Point Sur, DP05-09May17-MOC10B175N-095-N3, 28. 95125 and -87.91466, 09 May 2018, 6-1451 m, MOCNESS plankton net, L. Timm, coll.

Zoea. Size: $8 \mathrm{~mm}$ (Carapace length); $26 \mathrm{~mm}$ (Total length). $\mathrm{N}=1$.

Carapace (Figure $4 \mathrm{~A}$ ). Rostrum straight, reaching the end of the cornea, unarmed; epigastric spine present; eyes pedunculate.

Pleon (Figure 4A) with 6 somites, no spines or setae. Pleopods 1-4 missing in the specimen, pleopod 5 without setae.

Antennule (Figure 4B). Peduncle 3-segmented, article 1 the longest, slender, with 23 plumose setae; article 2 with 8 plumose setae and article 3 with 9 plumose setae and two flagella distally.

Antenna (Figure 4C). Protopod 3-segmented with a flagellum; exopod flattened with 73 plumose setae.

Mandible (Figure 4D) without mandibular palp; incisor with 7 terminal teeth.

Maxillule (Figure 4E). Coxal endite with 5 simple setae; basial endite with 15 (10 simple setae plus 5 conical setae) and protopod with one simple setae.

Maxilla (Figure 4F). Coxal endite with 6 simple setae; basial endite bilobed with $3+4$ simple setae; endopod with $2(1+1)$ simple setae; scaphognathite (damage in the specimen) margin with 26 plumose setae.

First maxilliped (Figure 4G). Coxa with 7 simple setae; basis with 28 simple setae; endopod unsegmented with $3(2+1)$ plumose setae; exopod unsegmented with 35 plumose setae.

Second maxilliped (Figure $4 \mathrm{H}$ ). Coxa with one simple setae; basis with 3 simple setae; endopod 5-segmented with 0, 1, 0, 1, 1 simple setae; exopod missing in the specimen.

Third Maxilliped (Figure 4I). Coxa and basis without setae; endopod 4-segmented with $0,0,0,12$, simple setae; exopod missing in the specimen.

First to fifth Pereopods missing in the specimen.

Uropod (Figure 4J). Endopod well developed with 53 plumose setae; exopod, slightly wider than endopod, with 80 plumose setae.

Telson (Figure 4K) elongate, subtriangular, armed with two pairs of dorsolateral spines close to the posterior margin. Posterior margin with a pointed projection, armed with two principal spines in each corner. 

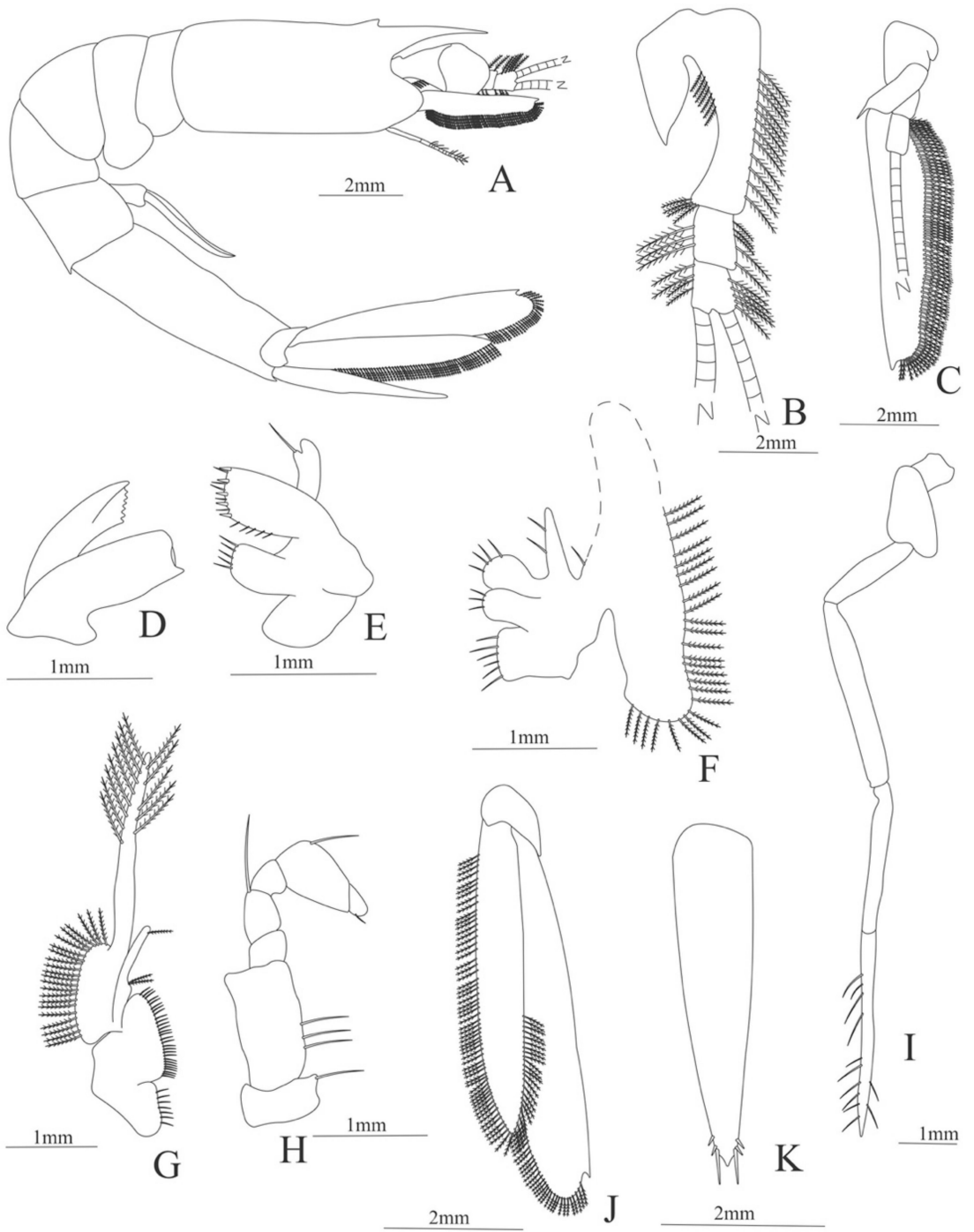

Figure 4. Meningodora longisulca: (A) lateral view; (B) antennule; (C) antenna, (D) mandible; (E) maxillule; (F) maxilla; (G) first maxilliped; (H) second maxilliped; (I) third maxilliped; (J) uropods; (K) telson.

$$
\begin{aligned}
& \text { Meningodora vesca (Smith, 1886) } \\
& \text { (Figures } 5 \text { and 6) }
\end{aligned}
$$

Material examined: Gulf of Mexico, HBG 7939, R/V Point Sur, DP05-08May17-MOC10B003D-092-N4, 27. 9271 and -87.0178, 8 May 2017, 600-400 m, MOCNESS plankton net, L. Timm, coll. Gulf of Mexico, HBG 7999, R/V Point Sur, DP05-03May17-MOC10-B065N087-N3, 28.53128 and -88.0236, 3 May 2017, 1000-600 m, MOCNESS plankton net, L. Timm, coll.

Decapodite. Size. $14 \mathrm{~mm}$ (Carapace length); $43 \mathrm{~mm}$ (Total length). $\mathrm{N}=2$.

Carapace (Figure 5A). Rostrum slightly beyond the cornea and armed with 8 dorsal and one ventral spines; strong branchiostegal spine; eyes pedunculate.

Pleon (Figure 5A) with 6 somites, no spines or setae. Pleopods 1-2 well developed, pleopods $3-5$ missing in the specimen.

Antennule (Figure 5B). Peduncle 3-segmented, article 1 the longest, slender, with 12-16 plumose setae; article 2 with 5-6 plumose setae and article 3, subequal in size with article 2, with 11-15 plumose setae and two flagella distally.

Antenna (Figure 5C). Protopod 3-segmented (flagellum missing in the specimen); exopod flattened with 59-74 plumose setae. 
Mandible (Figure 5D). Mandibular palp 3-segmented, armed with 2, 4, 3 simple setae; incisor with 7 terminal teeth.

Maxillule (Figure 5E). Coxal endite with 38 serrulated setae; basial endite with 16 conical setae and a subterminal simple seta; protopod unarmed.

Maxilla (Figure 5F). Coxal endite with 21 plumose setae; basial endite bilobed with $16+19$ serrulated setae; exopod with 5 plumose setae; scaphognathite (damage in the specimen) margin with 102 plumose setae.

First maxilliped (Figure 5G). Coxa with 2 plus 5 plumose setae; basis with 42-46 serrulated setae; endopod with $7(2+3+2)$ plumose setae; exopod with 36-38 plumose setae.

Second maxilliped (Figure 5H). Coxa without setae; basis with 4-6 simple setae; endopod 5-segmented with 5-11 simple, 0-5, 3-5 simple, 4-12 simple, 9-11 plumose setae; exopod unsegmented and armed with 12-16 plumose setae.

Third maxilliped (Figure 5I). Coxa without setae; basis with 3 simple setae; endopod 3-segmented with 33 simple, 10 simple, 21 (7 simple +14 plumose) setae; exopod unsegmented and armed with 15 plumose setae.

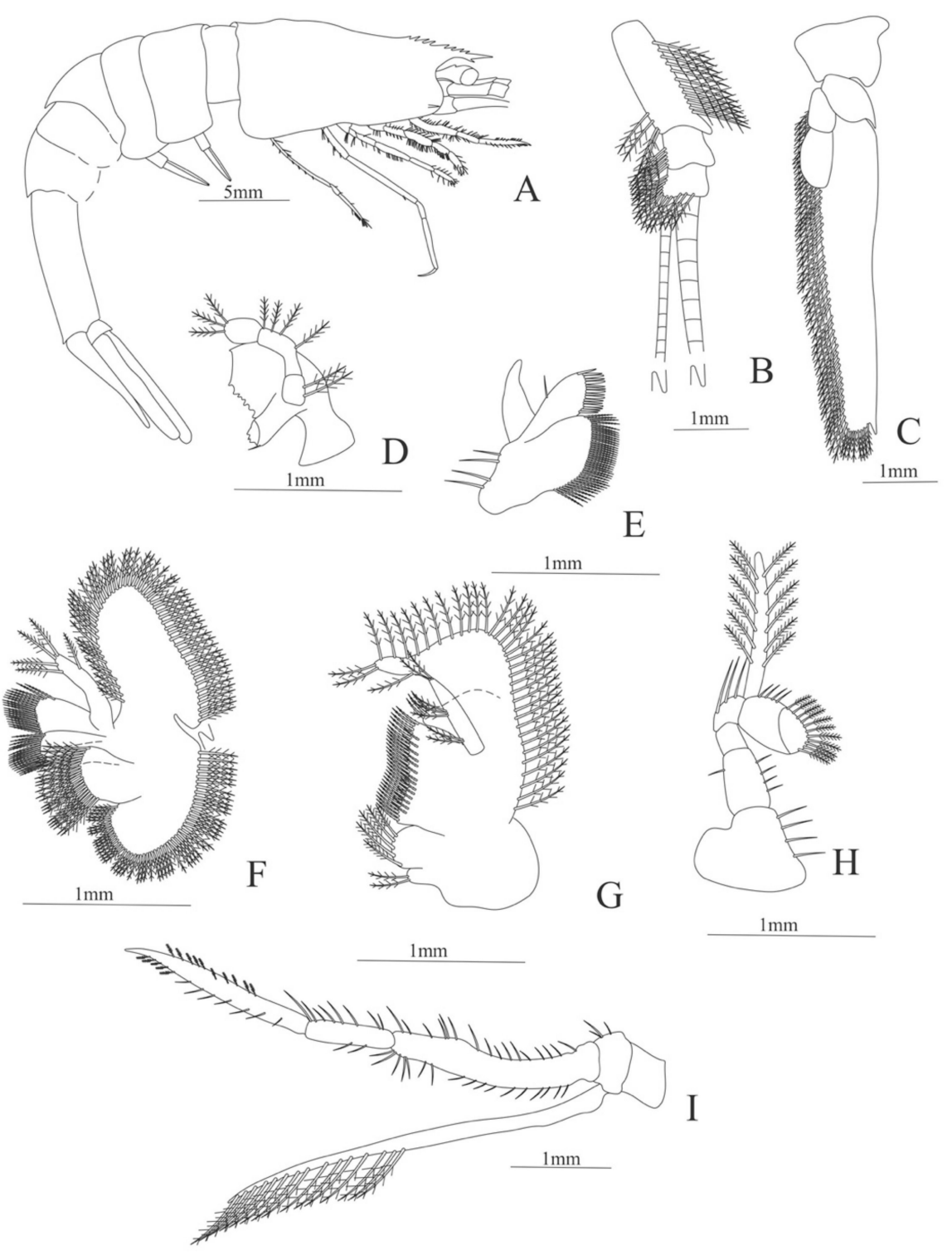

Figure 5. Meningodora vesca: (A) lateral view; (B) antennule; (C) antenna; (D) mandible; (E) maxillule; (F) maxilla; (G) first maxilliped; (H) second maxilliped; (I) third maxilliped. 
First pereopod (Figure 6A). Coxa with 7-9 simple setae; basis with 4 simple setae; endopod 5-segmented with 10 (5 plumose plus 5 simple), 14-29 simple, 7-13 plumose, 7-10 simple, 2-4 simple setae; exopod unsegmented and unarmed.

Second pereopod (Figure 6B). Coxa with 4 simple setae. Basis with 3 simple setae; endopod 5-segmented with 6, 12, 2, 10, 3 simple setae; exopod unsegmented with 5 simple setae.

Third pereopod (Figure 6C). Coxa with 3 simple setae. Basis with 5 simple setae; endopod 5-segmented with 4 ( 3 spines plus one simple seta), one spine, 0, 0, 0 setae; exopod unsegmented and unarmed.

Fourth pereopod missing in the specimen.

Fifth pereopod (Figure 6D). Coxa and basis with one simple seta each one; endopod 4-segmented with 7 ( 3 spines plus 4 simple setae), 4 spines, 2 simple setae, 19 (8 simple setae plus 11 plumose setae).

Uropod (Figure 6E). Endopod well developed with 53-65 plumose setae; exopod, slightly wider than endopod, with 80-82 plumose setae.

Telson (Figure 6F) Damaged in the specimen. Elongate, subtriangular, armed with 3 pairs of dorsolateral spines. Posterior margin with a pointed projection.

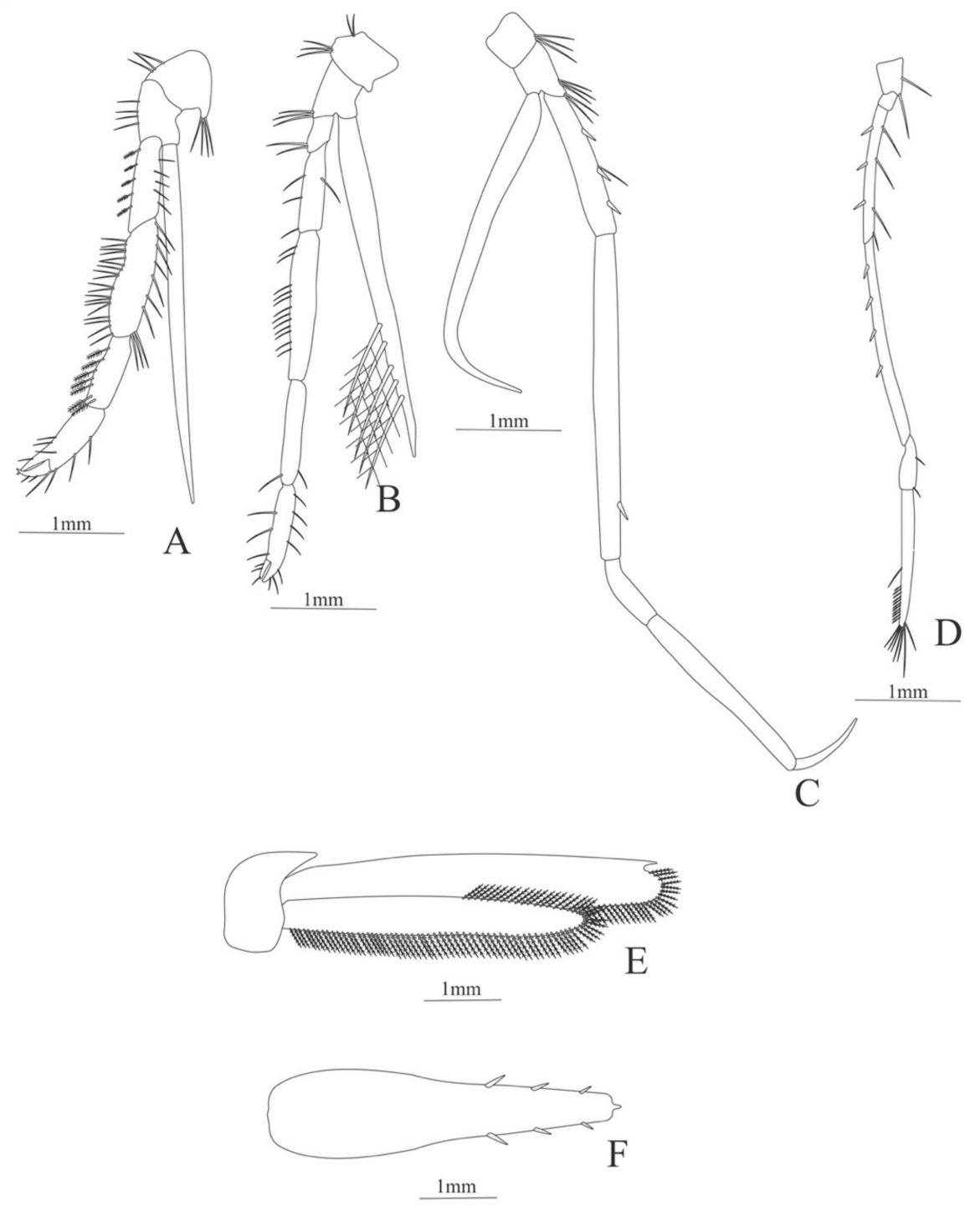

Figure 6. Meningodora vesca: (A) first Pereopod; (B) second Pereopod; (C) third Pereopod; (D) fifth Pereopod; (E) uropods; (F) telson. 
Ephyrina Smith, 1885

Ephyrina ombango Crosnier and Forest, 1973

(Figure 7)

Material examined: Gulf of Mexico: HBG7902, R/V Point Sur, DP05-01May17-MOC10B081D-084-N3, 28.5116, -87.0153, 1 May 2017, 1000-600 m, MOCNESS plankton net, L. Timm, coll.

Zoea. Size. $4 \mathrm{~mm}$ (Carapace length); $16 \mathrm{~mm}$ (Total length). $\mathrm{N}=1$.

Carapace (Figure 7A). Rostrum small, not reach the cornea, unarmed; anteroventral margin bearing small pterygostomian spine; eyes pedunculate.

Pleon (Figure 7A) with 6 somites, no spines or setae. Pleopods $1-3$ missing in the specimen, pleopods $4-5$ without setae.

Antennule (Figure 7B). Peduncle 3-segmented, article 1 the longest, slender, with 5 simple setae; article 2 also with 3 simple setae and article 3 with two flagella distally.

Antenna (Figure 7C). Protopod 2-segmented (flagellum missing in the specimen); exopod flattened with 46 plumose setae.

Mandible (Figure 7D,E). Mandibular palp 3-segmented, with 4, 1, 8 plumose setae; right incisor with 6 teeth and left incisor with 8 teeth.

Maxillule (Figure 7F). Coxal endite with 24 (10 plumose plus 14 serrulated) setae; basial endite with 18 conical serrulated setae and a subterminal simple setae; protopod with 4 simple setae.

Maxilla (Figure 7G). Coxal endite with 33 plumose setae; basial endite bilobed with $12+25$ plumose setae; endopod with $5(1+1+1+2)$ plumose setae; scaphognathite margin with 88 plumose setae.

First maxilliped (Figure $7 \mathrm{H}$ ). Coxa with 16 plumose setae; basis with 42 plumose setae; endopod unsegmented with 1, 1, 1, 3, plumose setae; exopod unsegmented with 42 simple setae.

Second maxilliped (Figure 7I). Coxa with 4 plumose setae; basis with 12 plumose setae; endopod 5-segmented with 8,1,7,11,0 plumose setae, except in the article 4 where all the setae were serrulated; exopod unsegmented, armed distally with 2 plumose setae.

Third maxilliped (Figure 7J). (Damaged in the specimen) Coxa without setae; basis with 4 simple setae; endopod 4-segmented with 14, 23, 20, 7, plumose setae.

First to Fifth Pereopod missing in the specimen.

Uropod (Figure 7K) with rami subequal. Endopod (Damaged in the specimen) with 85 plumose setae; exopod, slightly wider than endopod, with 75 plumose setae.

Telson (Figure 7L) elongate, subtriangular, armed with 8 pairs of dorsolateral spines. Posterior margin armed with a terminal spine.

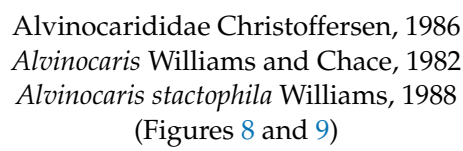

Material examined: Gulf of Mexico: HBG 8811, R/V Point Sur, DP06-20Jul18-MOC10B001D-101-N0, 28. 95125 and -87.91466, 29.01879 and -88.02719, 20 July 2018, 6-1451 m, MOCNESS plankton net, L. Timm coll; Gulf of Mexico: HBG 8848, R/V Point Sur, DP0624Jul18-MOC10-B251N-106-N3, 28. 540167, -88.47116 and 28.5122, -88.6337, 24 July 2018, 602-1001 m, MOCNESS plankton net, L. Timm, coll.

Decapodite. Size. $7 \mathrm{~mm}$ (Carapace length); $19 \mathrm{~mm}$ (Total length). $\mathrm{N}=2$.

Carapace (Figure 8A). Rostrum straight, armed dorsally with 11-12 spines, longer than antennular peduncle; antennal spine small; anteroventral margin bearing small pterygostomian spine; eyes pedunculate. 


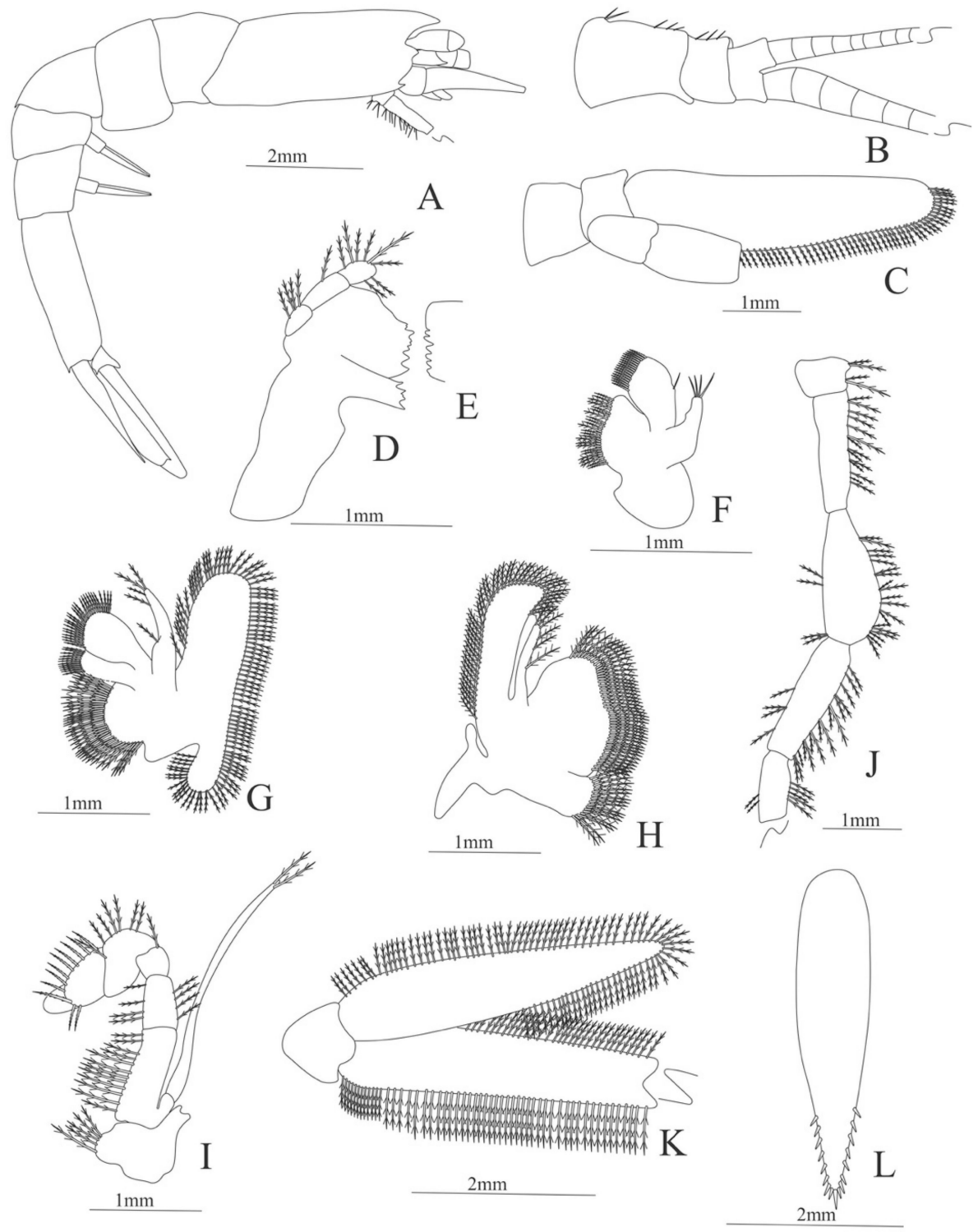

Figure 7. Ephyrina ombango: (A) lateral view; (B) antennule; (C) antenna; (D) left mandible; (E) right mandible (cutting edge); (F) maxillule; (G) maxilla; $(\mathbf{H})$ first maxilliped; (I) second maxilliped; (J) third maxilliped; (K) uropods; (L) telson.

Pleon (Figure 8A) with 6 somites, no spines or setae. Pleopods 1-3 missing in the specimen, pleopods $4-5$ well developed.

Antennule (Figure 8B). Peduncle 3-segmented, article 1 the longest, slender, article 2 also with plumose setae in both margins and article 3, the smallest, with two flagella distally. Flagella short, almost same size.

Antenna (Figure 8C). Protopod 3-segmented with a flagellum; exopod flattened with 63-65 plumose setae, endopod unarmed and unsegmented.

Mandible (Figure 8D). Mandibular palp 2-segmented, article 1 unarmed, article 2 with 4 simple setae; incisor with 5 terminal teeth.

Maxillule (Figure 8E). Coxal endite with 13 simple setae; basial endite with 11 simple setae and protopod with 6 setae $(1+1+1+2)$.

Maxilla (Figure $8 \mathrm{~F}$ ). Coxal endite with 21-22 simple setae; basial endite bilobed with $13+10$ simple setae; endopod with $8(3+1+2+2)$ plumose setae; scaphognathite margin with 116-120 plumose setae and 18-20 simple terminal long setae. 
First maxilliped (Figure 8G). Coxa with 7-13 simple setae; basis with 28-29 plumose setae; endopod unsegmented with 1, 2, 1, 1, 2 (1 outer plus 1 terminal) plumose setae; exopod unsegmented with $27-31$ simple setae.

Second maxilliped (Figure $8 \mathrm{H}$ ). Coxa without setae; basis with 2 simple setae; endopod 5-segmented with 6-11, 1-3, 0-2, 0, 1-3 simple setae; exopod unsegmented, armed distally with 2-4 plumose natatory setae.

Third maxilliped (Figure 8I). Coxa without setae; basis with 4-5 simple setae; endopod 5-segmented with 2, 2, 5, 7, 2 simple setae; exopod unsegmented, armed distally with 6 plumose natatory setae.

First pereopod (Figure 8J). Coxa and basis without setae; endopod 5-segmented with 2, 2, 1, 6, 0 simple setae; exopod unsegmented, armed distally with 2-6 plumose natatory setae.

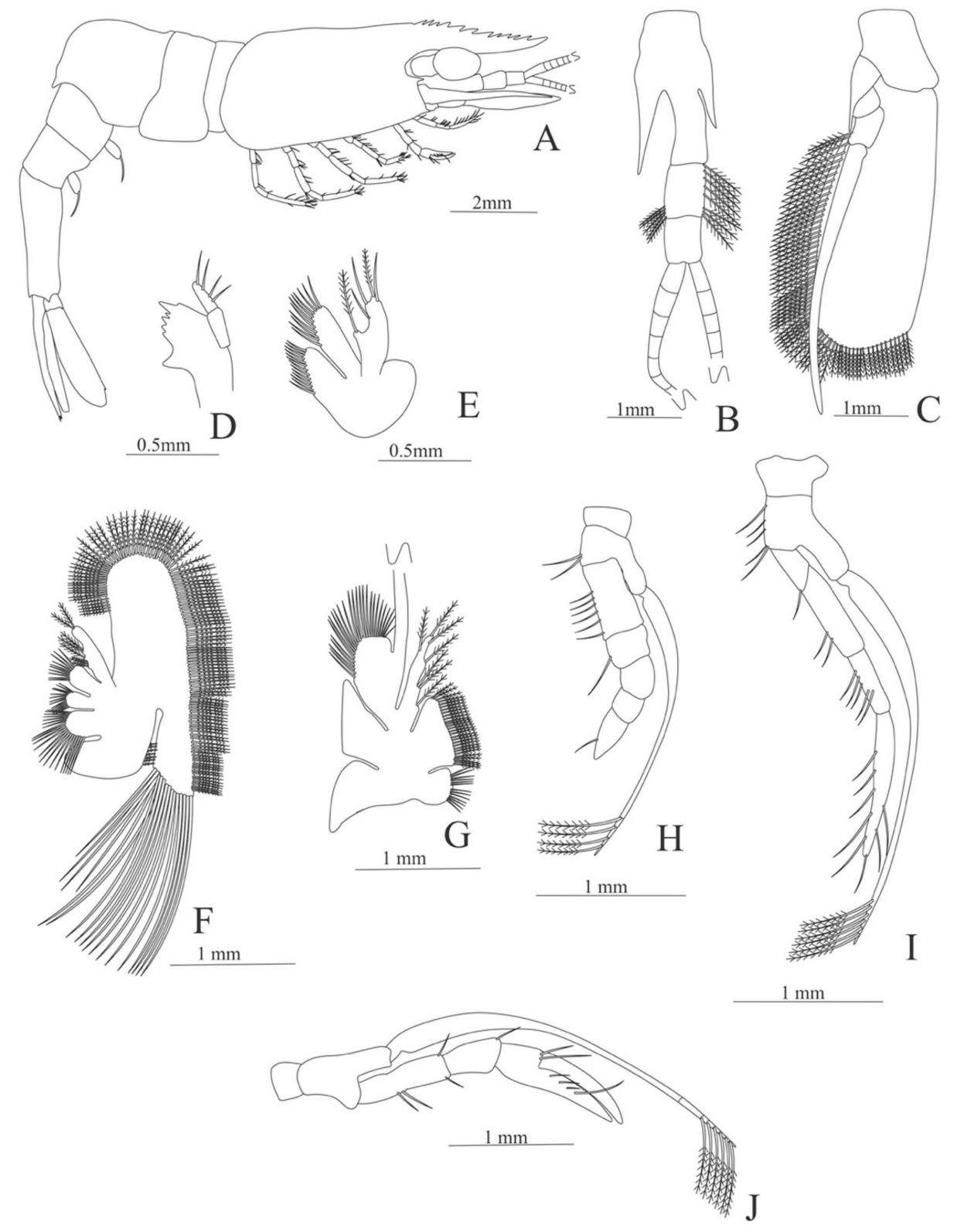

Figure 8. Alvinocaris stactophila: (A) lateral view; (B) antennule; (C) antenna; (D) mandible; (E) maxillule; (F) maxilla; (G) first maxilliped; (H) second maxilliped; (I) third maxilliped; (J) first pereopod. 
Second pereopod (Figure 9A). Coxa without setae. Basis with 2 simple setae; endopod 5-segmented with 2, 6, 0, 7, 3 simple setae; exopod unsegmented, armed distally with 2-6 plumose natatory setae.

Third pereopod (Figure 9B). Coxa without setae. Basis with 2 simple setae; endopod 5-segmented with 3, 5, 1, 7, 0 simple setae; exopod unsegmented, armed distally with 1-8 long, plumose natatory setae.

Fourth pereopod (Figure 9C). Coxa without setae. Basis with 3 simple setae; endopod 5-segmented with 4, 5, 1, 6, 0 simple setae; exopod unsegmented, armed distally with 2-6 long, plumose natatory setae.

Fifth pereopod (Figure 9D). Coxa and basis unarmed; endopod 5-segmented with 4, 1, $1,8,0$ simple setae.

Uropod (Figure 9E) with rami subequal. Endopod well developed with 54-58 plumose setae; exopod, slightly wider than endopod, with 64-68 plumose setae.

Telson (Figure 9F) elongate, subrectangular, armed with 4 pairs of dorsolateral spines. Posterior margin convex, armed with 2 principal spines in each corner and 6 small spines on distal margin between.

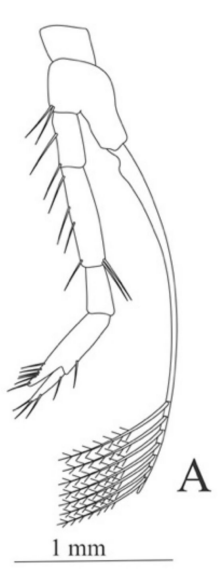

A

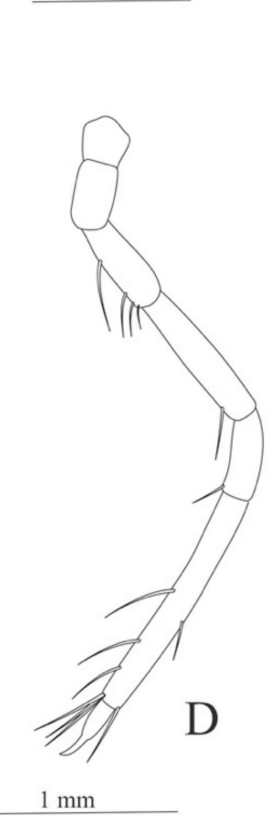

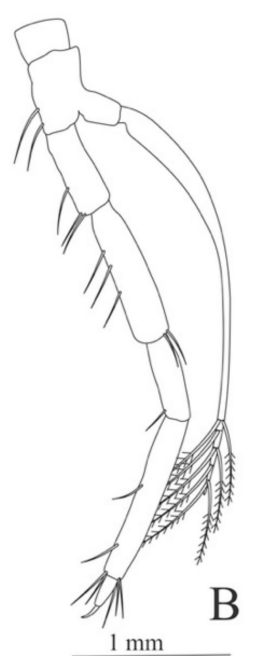

$\mathrm{B}$

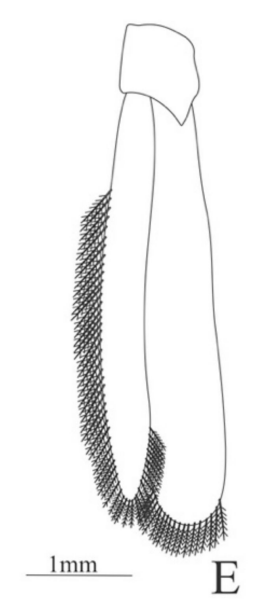

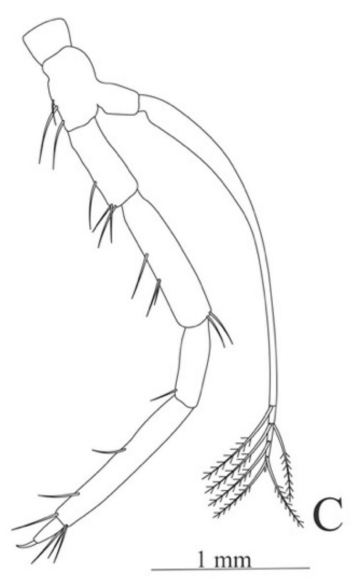

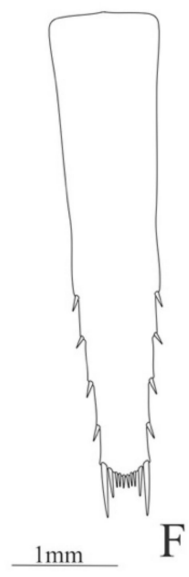

Figure 9. Alvinocaris stactophila: (A) second pereopod; (B) third pereopod; (C) fourth pereopod; (D) fifth pereopod; (E) uropods; (F) telson. 


\author{
Eugonatonotidae Chace, 1937 \\ Eugonatonotus Schmitt, 1926 \\ Eugonatonotus crassus (A. Milne Edwards, 1881) \\ (Figures 10 and 11)
}

Material examined: Gulf of Mexico: HBG 6822, R/V Point Sur, DP04-08Aug16, MOC10-SE1N-063-N0, from 26.9878 and -87.9494 to 27.0591 and $-88.0856,8$ August 2016, 1504.9-N/A m, MOCNESS plankton net, H. Bracken-Grissom, coll.

Zoea. Size. $6 \mathrm{~mm}$ (Carapace length); $19 \mathrm{~mm}$ (Total length). $\mathrm{N}=1$.

Carapace (Figure 10A). Rostrum short and unarmed; eyes pedunculate.

Pleon (Figure 10A) with 6 somites, no spines or setae. Pleopods 1-3 missing in the specimen, pleopods $4-5$ without setae.

Antennule (Figure 10B). Peduncle 3-segmented, article 1 the longest, slender, with 17 plumose setae; article 2 with 6 plumose setae and article 3, subequal in size with article 2, with 6 plumose setae and two flagella distally, flagella short, almost same size.

Antenna (Figure 10C). Protopod 3-segmented with a flagellum; exopod flattened with 35 plumose setae.

Mandible (Figure 10D). Mandibular palp 3-segmented, article 1 and 2 unarmed, article 3 with 4 simple setae; incisor with 7 terminal teeth.

Maxillule (Figure 10E). Coxal endite with 6 simple setae; basial endite with 6 simple setae and protopod with 12 setae $(2+2+12)$.

Maxilla (Figure 10F). (Damaged in the specimen) Coxa 1 without setae; basial endite with 16 simple setae; scaphognathite margin with 57 plumose setae.

First maxilliped (Figure 10G). Coxa with 4simple setae plus one plumose set; basis with 14 plumose setae; endopod 4-segmented with 7, 4, 7, 3, 2 simple setae, except the last article that bear 2 plumose and one simple setae; exopod unsegmented with 26 simple setae

Second maxilliped (Figure 10H). Coxa without setae; basis with 11 simple setae and 2 plumose setae; endopod 4-segmented with 6 simple, 13 simple, 2 simple, 10 (9 simple plus one plumose) setae; exopod unsegmented and unarmed.

Third maxilliped (Figure 10I). Coxa without setae; basis with 7 simple setae; endopod 5-segmented with 6, 8, 4, 17, 5 simple setae; exopod unsegmented and unarmed.

First pereopod (Figure 10J). Coxa and basis without setae; endopod 5-segmented with 2, 2, 1, 6, 0 simple setae; exopod unsegmented, armed distally with 6 plumose natatory setae.

Second pereopod (Figure 11A). Coxa without setae. Basis with one simple setae; endopod 5-segmented with 5, 8, 5, 16, 1 simple setae; exopod unsegmented and unarmed.

Third pereopod (Figure 11B). Coxa without setae. Basis with one simple setae; endopod 5-segmented with 6, 5, 1, 10,1 simple setae; exopod unsegmented, armed distally with 15 simple setae.

Fourth pereopod (Figure 11C). Coxa and basis without setae; endopod 5-segmented with 1, 1, 3, 10, 4 simple setae; exopod unsegmented and unarmed.

Fifth pereopod (Figure 11D). Coxa without setae; basis with 3 simple setae and one plumose setae; endopod 5-segmented with 8, 11,3, 10, 0 simple setae.

Uropod (Figure 11E) with rami subequal. Endopod well developed with 54 plumose setae; exopod, slightly wider than endopod, with 68 plumose setae.

Telson (Figure 11D) elongate, subtriangular. Posterior margin, armed with 2 principal spines in each corner and 6 small spines. 


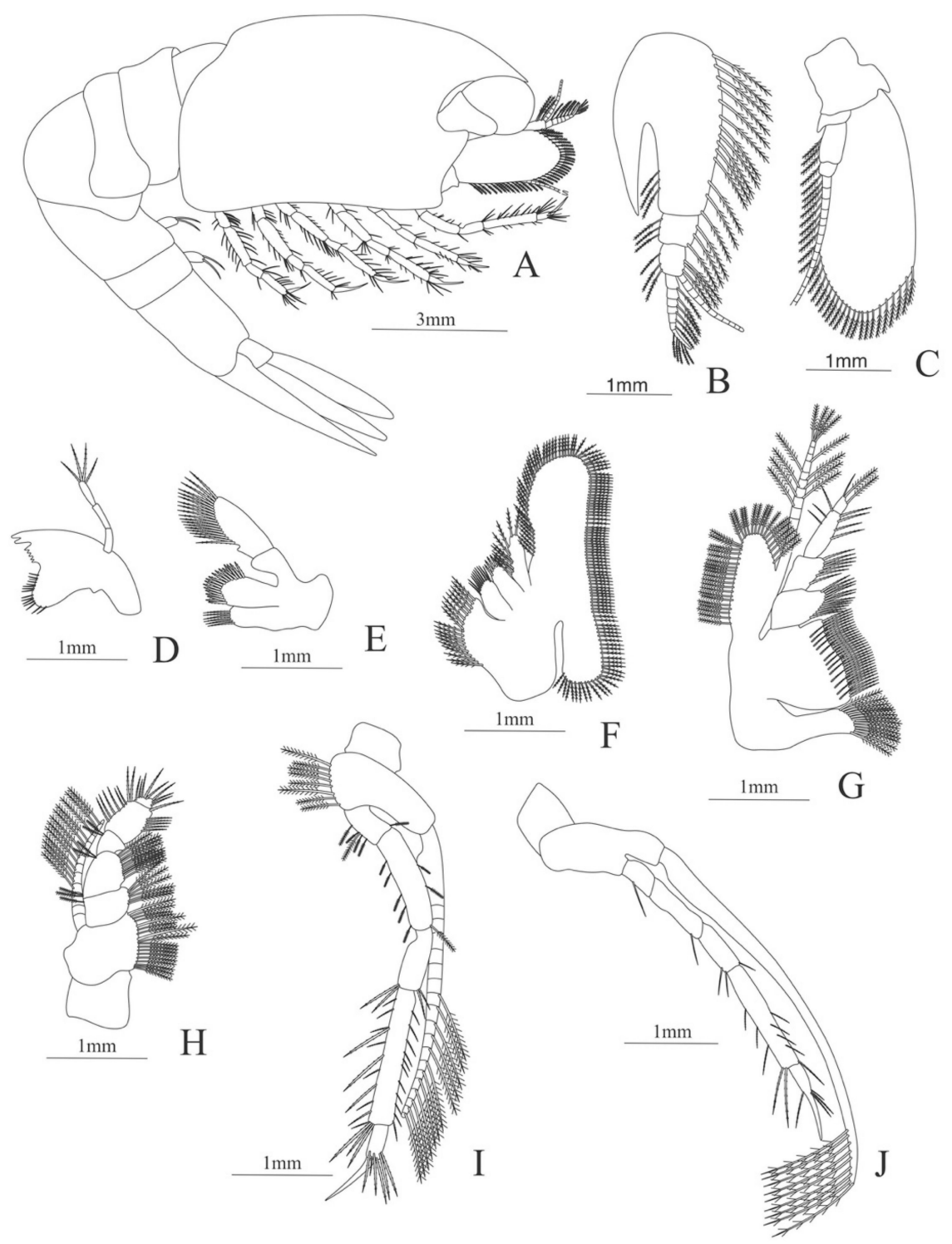

Figure 10. Eugonatonotus crassus: (A) lateral view; (B) antennule; (C) antenna; (D) mandible; (E) maxillule; (F) maxilla; (G) first maxilliped; (H) second maxilliped; (I) third maxilliped; (J) first pereopod.

Nematocarcinidae Smith, 1884

Nematocarcinus A. Milne-Edwards, 1881 Nematocarcinus cursor A. Milne-Edwards, 1881

(Figures 12 and 13)

Material examined: Florida Straits: HBG 6202, R/V Walton Smith, BLV01-19Jul16STNB-D005, from 25.421423 and -79.648933 to 25.405617 and $-79.661217,19$ July 2016, 700-500 m, Trawl plankton net, H. Bracken-Grissom, coll.

Zoea. Size. $7 \mathrm{~mm}$ (Carapace length); $21 \mathrm{~mm}$ (Total length). $\mathrm{N}=1$.

Carapace (Figure 12A). Rostrum shorter than the cornea, armed dorsally with 5 spines, epigastric spine present; eyes pedunculate; pterygostomial spine present.

Pleon (Figure 12A) with 6 somites, no spines or setae. Pleopod 4 missing in the specimen, pleopods $1-2$ and $4-5$ without setae.

Antennule (Figure 12B). Peduncle 3-segmented, article 1 the longest, slender, with four pointed projections and with 16 plumose setae; article 2 with one plumose setae and article 3 , subequal in size with article 2, with 8 plumose setae and two flagella distally, flagella almost same size. 

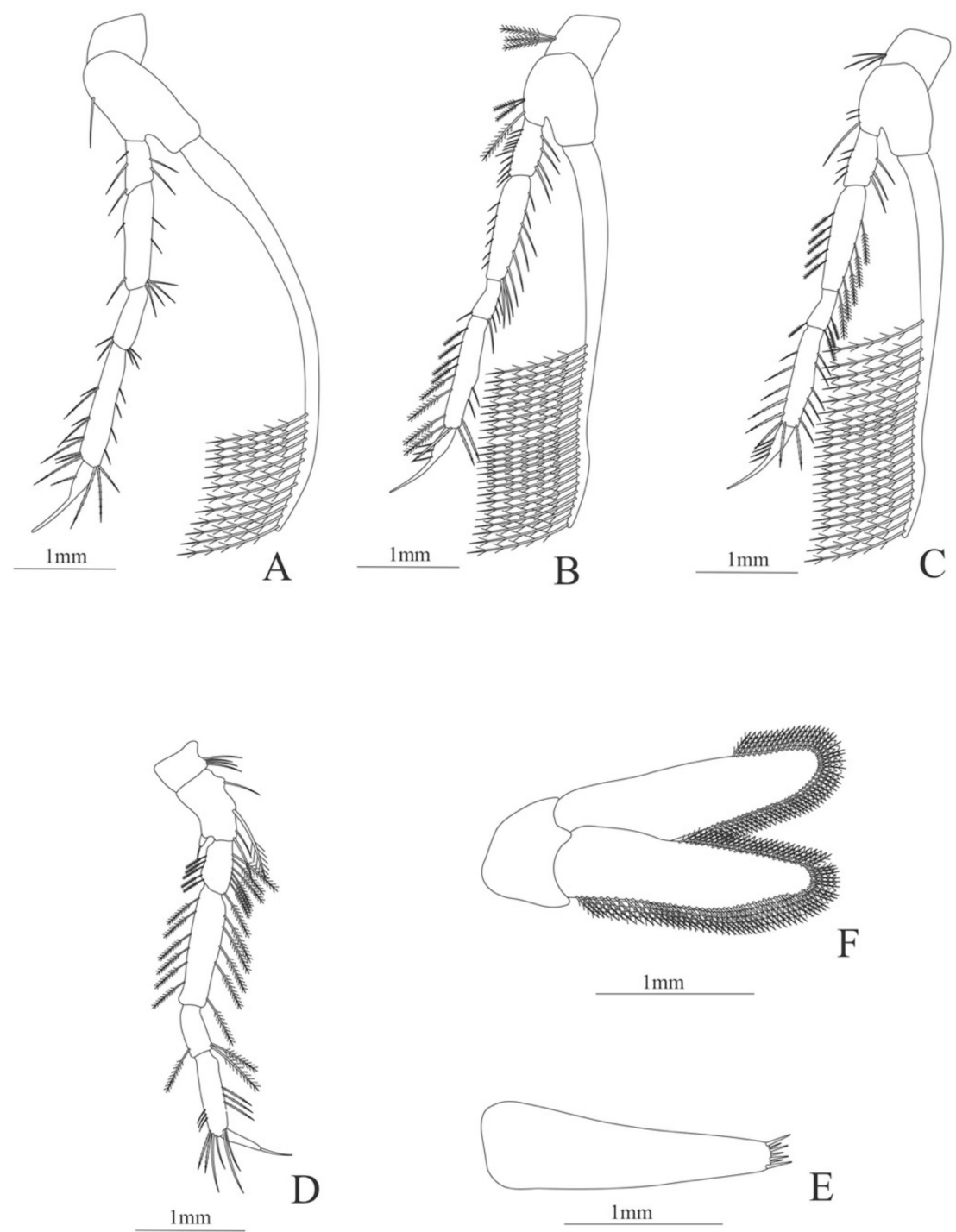

Figure 11. Eugonatonotus crassus: (A) second pereopod; (B) third pereopod; (C) fourth pereopod; (D) first pereopod; (E) uropods; (F) telson.

Antenna (Figure 12C). Protopod 3-segmented, segment 1 unarmed, segment 2 with two plumose setae, segment 3 with a flagellum; exopod flattened with 66 plumose setae.

Mandible (Figure 12D,E). Mandibular palp absent; left and right incisor with 3 terminal teeth.

Maxillule (Figure 12F). Coxal endite with 26 conical serrulated setae; basial endite with 11 simple setae and 13 conical serrulated setae; protopod with two articles, article 1 with two serrulated setae and article 2 with 6 serrulated setae.

Maxilla (Figure 12G). Coxa with 31 plumose setae; basial endite bilobed with 10 and 16 serrated setae respectively; scaphognathite margin with 127 plumose setae.

First maxilliped (Figure 12H). Coxa with 18 plumose setae; basis with 13 plumose and 17 serrulated setae; endopod 4-segmented with 6, 2, 2, 3, plumose setae, except the last segment that bear serrulated setae; exopod with 10 plumose setae.

Second maxilliped (Figure 12I). Coxa with 3 plumose setae; basis with 9 plumose setae; endopod 5-segmented with 5 plumose, 2 plumose, 1 plumose, 8 ( 5 plumose plus 3 serrulated), 5 serrulated setae; exopod unsegmented and unarmed.

Third maxilliped (Figure 12J). Coxa with 8 plumose setae; basis with 5 plumose setae; endopod 5-segmented with 4,3,3, plumose setae, one serrulated setae; last article 
subdivided in three small articles with 3, 2 and 2 serrulated setae; exopod armed with 10 plumose setae.

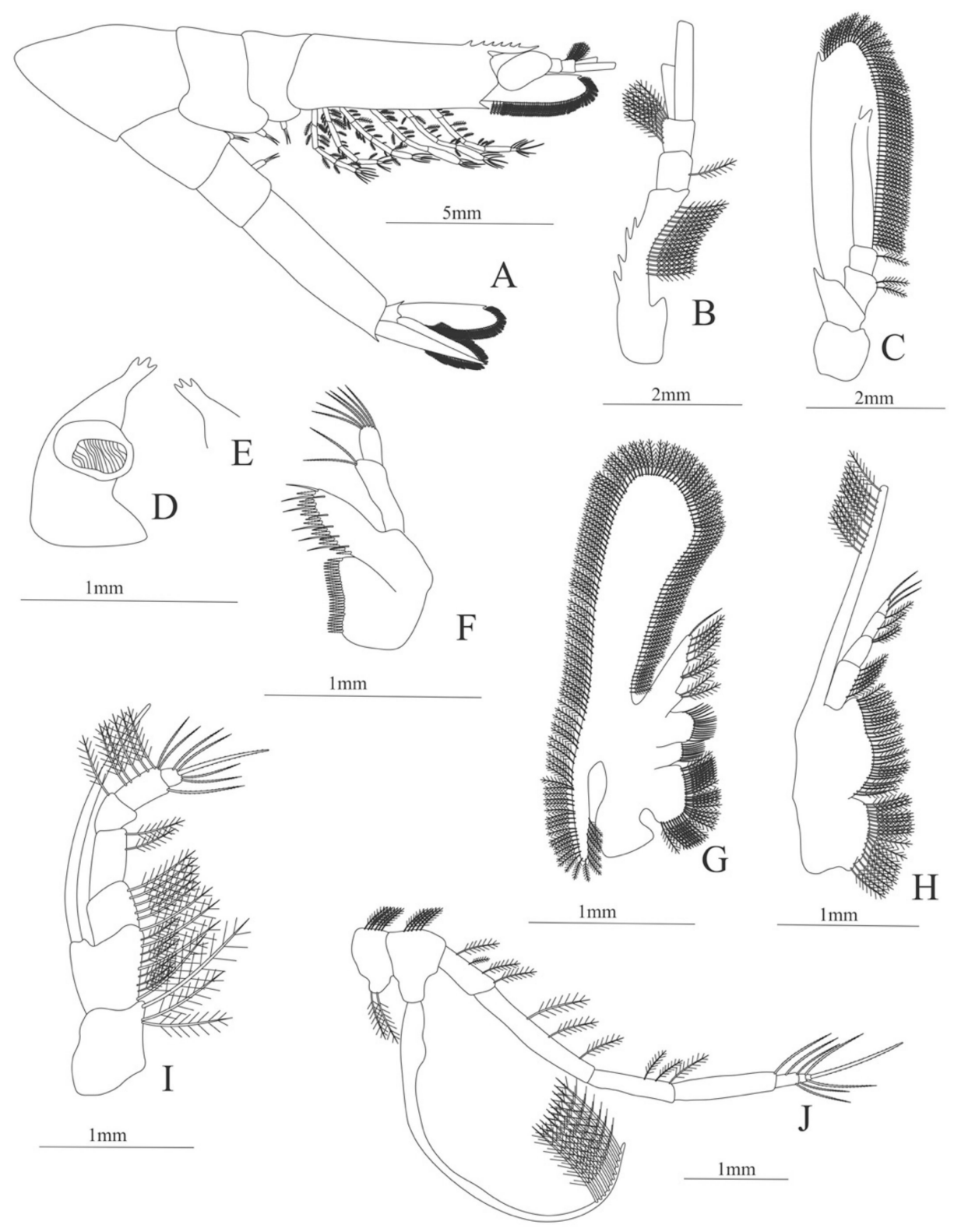

Figure 12. Nematocarcinus cursor: (A) lateral view; (B) antennule; (C) antenna; (D) left mandible; (E) right mandible (cutting edge); (F) maxillule; (G) maxilla; (H) first maxilliped; (I) second maxilliped; (J) third maxilliped.

First pereopod (Figure 13A). Coxa with 2 plumose setae, basis with 3 plumose setae; endopod 5-segmented with 5, 3, 2, 3, 4 plumose setae, except the last two segments that have serrulated setae; exopod, with 15 plumose setae.

Second pereopod (Figure 13B). Coxa with 2 plumose setae. Basis with 3 plumose setae; endopod 5-segmented with 3, 3, 3, 3, 3 plumose setae, except the last two segments that have serrulate setae; exopod with 9 plumose setae.

Third pereopod (Figure 13C). Coxa with 4 plumose setae, basis with one plumose setae; endopod 5-segmented with 6, 5, 5, 2, 3 plumose setae, except the last two segments that have serrulated setae; exopod with 13 plumose setae.

Four pereopod (Figure 13D). Coxa with 3 plumose setae, basis without setae; endopod 5 -segmented with 6, 10, 3, 4, 3 plumose setae, except the last two segment that have serrulated setae; exopod with 7 plumose setae. 
Fifth pereopod (Figure 13E). Coxa without setae; basis with 5 plumose setae; endopod 5 -segmented with 2, 3, 7, 4, 3 plumose setae setae, except the last two segments that have serrulated setae.

Uropods (Figure 13F). Endopod well developed with 72 plumose setae, slightly wider than exopod; exopod, with 76 plumose setae.

Telson (Figure 13G) elongate, subtriangular. Lateral margin with 8 pairs of spines. Posterior margin, armed with 2 principal spines in each corner and 6 small spines.
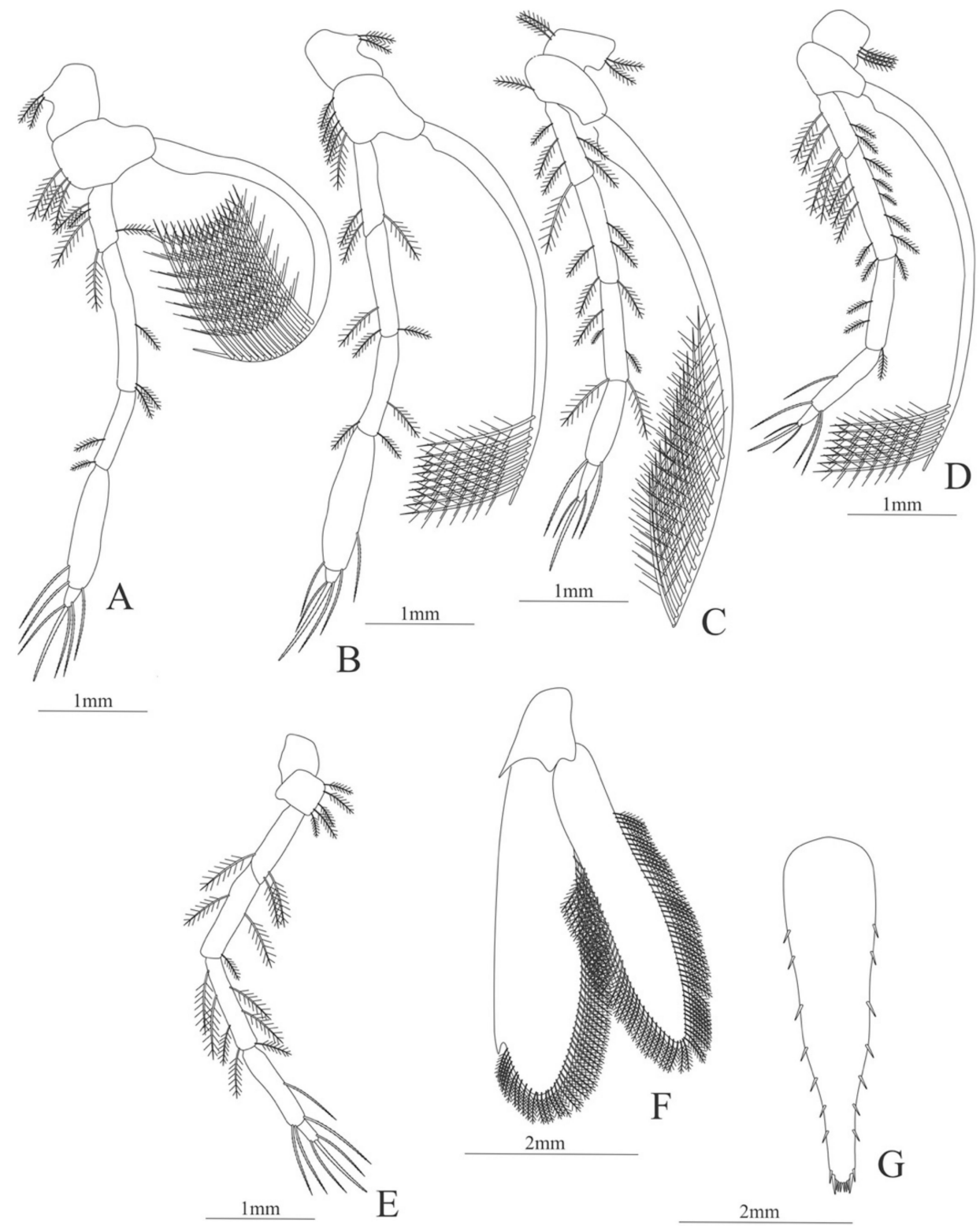

Figure 13. Nematocarcinus cursor: (A) first pereopod; (B) second pereopod; (C) third pereopod; (D) fourth pereopod; (E) fifth pereopod; (F) uropods; (G) telson.

Material examined: Gulf of Mexico: HBG 7555, R/V Point Sur, DP04-11Aug16, MOC10-SW3D-068-N5, from 27.01226 and -88.4618 to 26.9255 and -88.5970, 11 August 2016, 199.8-5 m, MOCNESS plankton net, H. Bracken-Grissom, coll.

Zoea. Size. $7 \mathrm{~mm}$ (Carapace length); $21 \mathrm{~mm}$ (Total length). $\mathrm{N}=1$. 
Carapace (Figure 14A). Rostrum shorter than the cornea, armed dorsally with four spines, epigastric spine present; eyes pedunculate; pterygostomial spine present.

Pleon (Figure 14A) with 6 somites, no spines or setae. Pleopods $3-4$ missing in the specimen, pleopods 1,2 and 5 without setae.

Antennule (Figure 14B). Peduncle 3-segmented, article 1 the longest, slender, with four pointed projections and with 16 plumose setae; article 2 with one plumose setae and article 3 , subequal in size with article 2, with 8 plumose setae and two flagella distally, flagella almost same size.

Antenna (Figure 14C). Protopod 3-segmented, segment 1 unarmed, segment 2 with two plumose setae, segment 3 with a flagellum; exopod flattened with 66 plumose setae.

Mandible (Figure 14D,E). Mandibular palp absent; left and right incisor with 3 terminal teeth.

Maxillule (Figure 14F). Coxal endite with 28 conical serrulated setae; basial endite with 11 simple setae and 13 conical serrulated setae; protopod with two articles, article 1 with two serrulated setae and article 2 with 6 serrulated setae.

Maxilla (Figure 14G). Coxal with 31 plumose setae; basial endite bilobed with 8 and 10 serrated setae respectively; scaphognathite margin with 122 plumose setae.

First maxilliped (Figure 14H). Coxa with 18 plumose setae; basis with 13 plumose and 17 serrulated setae; endopod 4-segmented with 5, 3, 1, 2, plumose setae, except the last article that bear 2 serrulated setae; exopod with 15 plumose setae.

Second maxilliped (Figure 14I). Coxa with 3 plumose setae; basis with 9 plumose setae; endopod 5-segmented with 3 plumose, 3 plumose, 1 plumose, 5 ( 2 plumose plus 3 serrulated), 5 serrulated setae; exopod unsegmented and unarmed.

Third maxilliped (Figure 14J). Coxa with 8 plumose setae; basis with 5 plumose setae; endopod 5-segmented with 3, 2, 2, plumose setae, one serrulated setae; last article subdivided in three small articles with 3,1 and 2 serrulated setae; exopod armed with 14 plumose setae.

First pereopod (Figure 15A). Coxa and basis with 3 plumose setae each one; endopod 5 -segmented with 5, 3, 4, 3, 4 plumose setae, except the last two segments that have serrulated setae; exopod, with 15 plumose setae.

Second pereopod (Figure 15B). Coxa with 2 plumose setae. Basis with 3 plumose setae; endopod 5-segmented with 4, 5, 0, 2, 3 plumose setae, except the last two segments that have serrulate setae; exopod damage in the specimen.

Third pereopod (Figure 15C). Coxa with 2 plumose setae, basis with 3 plumose setae; endopod 5-segmented with 6, 7, 4, 2, 3 plumose setae, except the last two segments that have serrulated setae; exopod with 18 plumose setae.

Four pereopod (Figure 15D). Coxa and basis with one plumose seta each; endopod 5-segmented with 7, 7, 5, 4 (one plumose and 3 serrulated), 3 plumose setae, except the last segment that have serrulated setae; exopod with 8 plumose setae.

Fifth pereopod (Figure 15E). Coxa without setae; basis with 5 plumose setae; endopod 5-segmented with 3, 4, 4, plumose setae, 4 (one plumose and 3 serrulated), 3 serrulated setae; exopod with 8 plumose setae.

Uropods (Figure 15F). Endopod well developed with 72 plumose setae, slightly wider than exopod; exopod, with 76 plumose setae.

Telson (Figure 15G). (Damaged in the specimen) elongate, subtriangular. Lateral margin with 7 pairs of spines. Posterior margin damage in the specimen. 


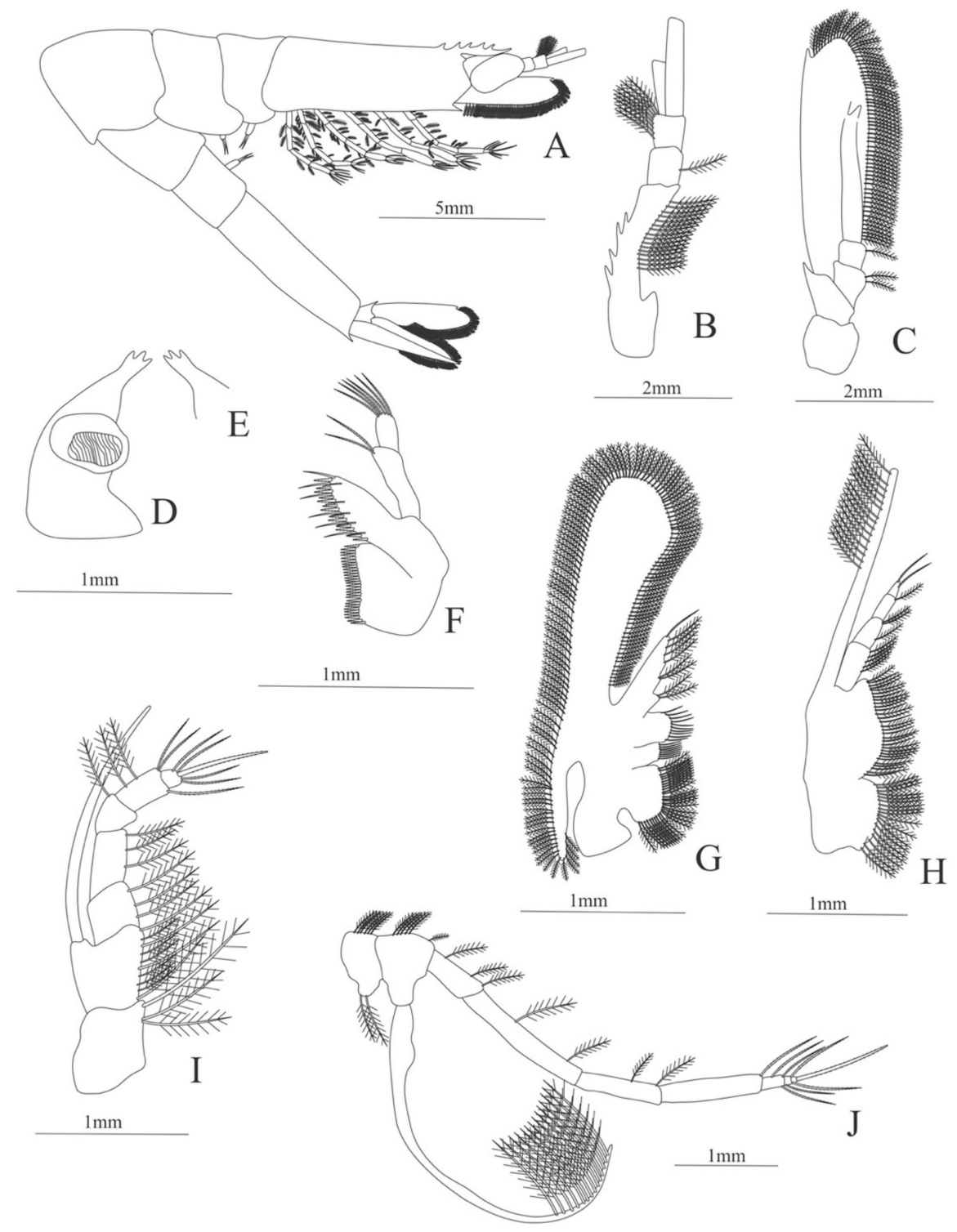

Figure 14. Nematocarcinus rotundus: (A) lateral view; (B) antennule; (C) antenna; (D) left mandible; (E) right mandible (cutting edge); (F) maxillule; (G) maxilla; (H) first maxilliped; (I) second maxilliped; (J) third maxilliped.

Material examined: Gulf of Mexico: HBG 6134, R/V Point Sur, DP03-06May16-MOC10B079N-045-N3, 27. 4613 and -86.8992, 27.5005 and -86.9771; 6 May 2016, 601.4-996.1 m. MOCNESS plankton net, L. Timm, coll. Gulf of Mexico: HBG 7996, R/V Point Sur, (DP05-06May17-MOC10-B287N-089-N3), 28.1179 and -87.3899; 6 May 2017, 1000-600 m, MOCNESS plankton net, L. Timm, coll. Gulf of Mexico: HBG 7997, R/V Point Sur, (DP05-06May17-MOC10-B287N-089-N3), 28. 1179 and -87.3899, 6 May 2017, 1000-600 m, MOCNESS plankton net, L. Timm, coll. Gulf of Mexico: HBG 8000, R/V Point Sur, DP05-03May17-MOC10-B065N-087-N3, 28. 5312 and -88.0236, 5 May 2017, 1000-600 m, MOCNESS plankton net, L. Timm, coll.

Decapodite. Size: $8 \mathrm{~mm}$ (Carapace length); $26 \mathrm{~mm}$ (Total length). $\mathrm{N}=4$.

Carapace (Figure 16A). Rostrum straight, armed with 7-12 dorsal spines, sligthly longer than antennular peduncle; eyes pedunculate. 

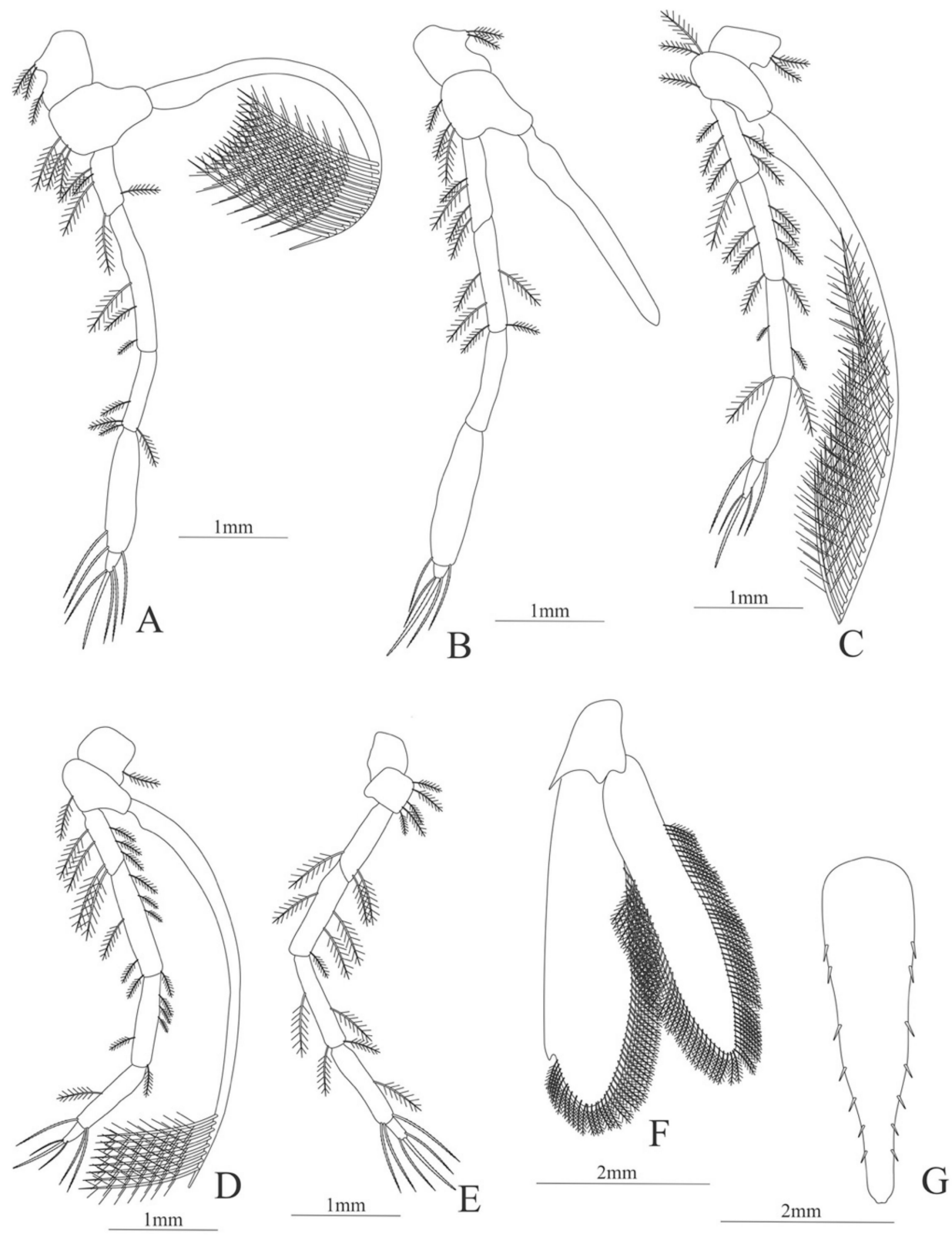

Figure 15. Nematocarcinus rotundus: (A) first pereopod; (B) second pereopod; (C) third pereopod; (D) fourth pereopod; (E) fifth pereopod; (F) uropods; (G) telson.

Pleon (Figure 16A) with 6 somites, no spines or setae. Pleopods well developed.

Antennule (Figure 16B). Peduncle 3-segmented, article 1 the longest, slender, with 15-24 plumose setae; article 2 with 15-17 plumose setae and article 3, subequal in size with article 2, with 8-16 plumose setae and two flagella distally, flagella almost same size.

Antenna (Figure 16C). Protopod 3-segmented, segment 1 unarmed, segment 2 with two plumose setae, segment 3 with a flagellum; exopod flattened with 66-83 plumose setae.

Mandible (Figure 16D). Mandibular palp 3-segmented, with 1, 8, 13 simple setae; incisor with 7 terminal teeth.

Maxillule (Figure 16E). Coxal endite with 8 serrulated setae; basial endite with 15 conical setae; protopod with 3 plumose setae.

Maxilla (Figure 16F). Coxal endite with 36 plumose setae; basial endite bilobed with 23 (12 plumose plus 11 conical) + 36 plumose setae; endopod with 6 plumose setae; scaphognathite margin with 149 plumose setae. 
First maxilliped (Figure 16G). Coxa without setae; basis with 47 (10 conical plus 10 plumose plus 27 serrulated) setae; endopod unsegmented with 21 plumose setae; exopod unsegmented with 21 simple setae

Second maxilliped (Figure 16H). Coxa without setae; basis with 8 simple setae; endopod 5-segmented with 11, 6, 2, all plumose, 25 (5 simple plus 20 serrulated setae), 11 serrulated; exopod unsegmented and unarmed.

Third maxilliped (Figure 16I). Coxa without setae; basis with 3 simple setae; endopod 4-segmented with 16, 20, 9 all simple, 29 serrulated setae; exopod missing in the specimen.

First to fifth Pereopods missing in the specimens.

Uropods (Figure 16J). Endopod well developed with 81-96 plumose setae, slightly wider than exopod; exopod, with 72-75 plumose setae.

Telson (Figure 16K) elongate, subtriangular. Lateral margin with 5 pairs of spines. Posterior margin, armed with 2 principal spines in each corner and 2 distal spines.
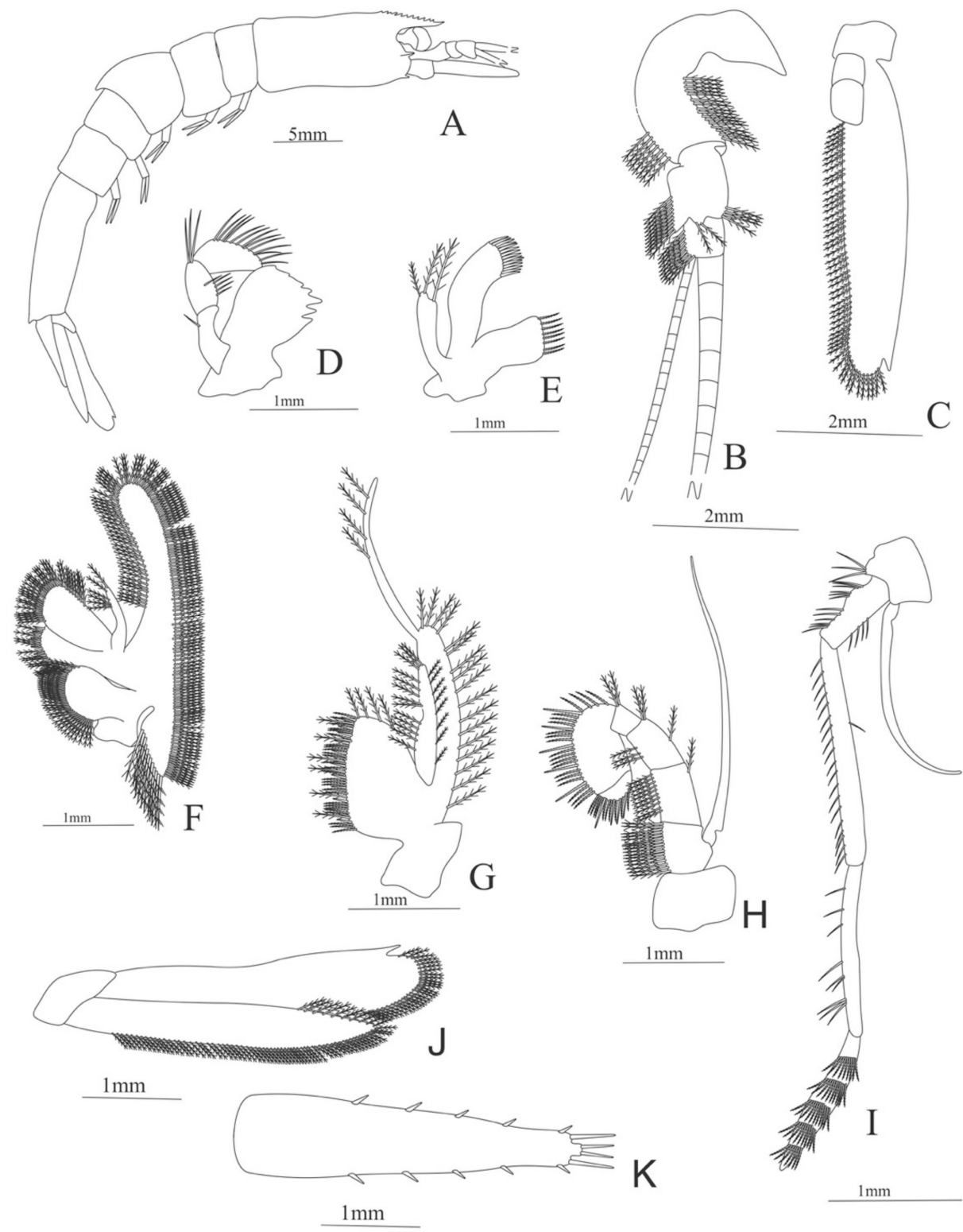

$1 \mathrm{~mm}$

Figure 16. Nematocarcinus rotundus: (A) lateral view; (B) antennule; (C) antenna; (D) mandible; (E) maxillule; (F) maxilla; (G) first maxilliped; (H) second maxilliped; (I) third maxilliped; (J) uropods; (K) telson. 


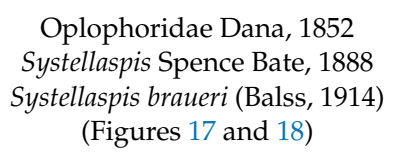

Material examined: Gulf of Mexico: HBG6823, R/V Point Sur, DP04-08Aug16-MOC10SE1N-063-N0, from 26.9878, -87.9494 to 27.0591, -88.0856, 8 August 2016, 1504-NA m, MOCNESS plankton net, H. Bracken-Grissom, coll.

Decapodite. Size. $8 \mathrm{~mm}$ (Carapace length); $26 \mathrm{~mm}$ (Total length). $\mathrm{N}=1$.

Carapace (Figure 17A). Rostrum straight, armed dorsally with 9 spines and ventrally with one small spine, same length of the eye; antennal spine small, anteroventral margin bearing one small spine and a pterygostomian spine; eyes pedunculate.

Pleon (Figure 17A) with 6 somites, no spines or setae. Pleopods 1-2 missing in the specimen, pleopods $3-5$ well developed.

Antennule (Figure 17B). Peduncle 3-segmented, article 1 the longest armed with 5 simple setae, article 2 also with 3 simple setae and article 3 the smallest, with one simple setae and two flagella distally, flagella subequal in size.

Antenna (Figure 17C). Protopod 3-segmented, flagellum missing in the specimen; exopod flattened with 52 plumose setae and a pointed process distally.

Mandible (Figure 17D). Mandibular palp 3-segmented, article 1 armed with 3 simple setae, article 2 with 2 lateral simple setae and article 3 with 6 simple setae plus 3 plumose setae, right incisor with 9 teeth.

Maxillule (Figure 17E). Coxal endite with 19 plumose setae; basial endite with 18 conical serrulate setae plus 2 plumose setae and protopod with one plumose subterminal seta.

Maxilla (Figure 17F). Coxal endite with 10 plumose setae; basial endite bilobed with $11+19$ (17 plumose plus 2 simple) setae; endopod with 3 plumose setae; scaphognathite margin with 124 plumose setae.

First maxilliped (Figure 17G). Coxa with 8 plumose setae; basis with 28 plumose setae; endopod unsegmented with 12 plumose setae; exopod unsegmented, armed with 14 plumose setae.

Second maxilliped (Figure 17H). Coxa without setae; basis with 6 plumose setae; endopod 5-segmented with 18, 8, 2, plumose setae plus 23, 12 serrulate setae; exopod unsegmented, armed distally with 8 plumose natatory setae.

Third maxilliped (Figure 18A). Coxa with 3 plumose setae; basis with 6 plumose setae, endopod 3-segmented with 40 (22 inner setae, 3 of them serrulate setae, all the others plumose +18 outer plumose setae), 9 serrulate setae and 23 serrulate setae; exopod unsegmented, armed distally with 7 plumose natatory setae.

First pereopod (Figure 18B). Coxa with 3 and basis with 6 plumose setae; endopod 5-segmented with 10 plumose setae, 18 plumose setae, 5, 11, 1 serrulate setae; exopod unsegmented and unarmed.

Second pereopod (Figure 18C). Coxa with 8 plumose setae, basis with 4 plumose setae; endopod 5-segmented with 17 plumose setae, 15 plumose setae and 4, 7, 1 serrulate setae.

Third pereopod missing in the specimen.

Fourth pereopod (Figure 18D). Coxa with 9 simple setae, basis with 4 simple setae; endopod 5 -segmented with 10 ( 5 spines +5 simple setae), 12 ( 4 spines +8 simple setae), 1 simple setae, 5 spines, 0, 0; exopod unsegmented and unarmed. 


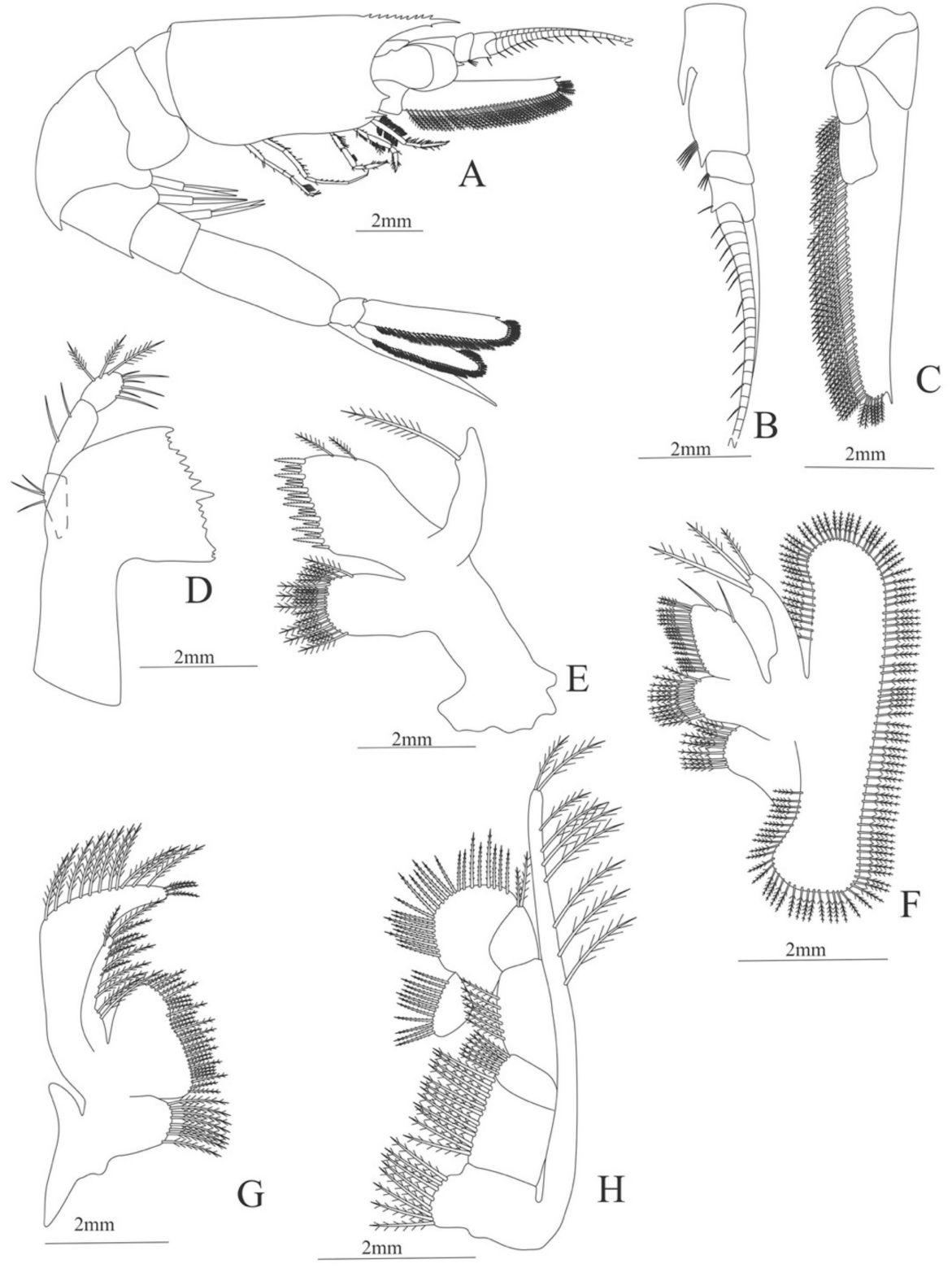

Figure 17. Systellaspis braueri: (A) lateral view; (B) antennule; (C) antenna; (D) mandible; (E) maxillule; (F) maxilla; (G) first maxilliped; (H) second maxilliped.

Fifth pereopod (Figure 18E). Coxa and basis without setae; endopod 5-segmented with 5 (2 spine +4 simple setae), 2, 3, 12, 8 simple setae; exopod unsegmented and unarmed.

Uropod (Figure 18F). Endopod well developed with 54 plumose setae; exopod with 42 plumose setae

Telson (Figure 18G) elongate, subtriangular, with 11 pairs of lateral spines, 1 pair of large mobile spines and 10 pairs of spines on the distal part near the tip of the telson; one small spine on the distal margin.

Material examined: Gulf of Mexico: HBG6844, R/V Point Sur, DP04-17Aug16-MOC10B252N-080-N5, from 28.5272, -87.4972 to 28. 3842, -87.4866, 17 August 2016, 199.5-5 m, MOCNESS plankton net, L. Timm, coll.

Zoea. Size. $22 \mathrm{~mm}$ (Carapace length); $36 \mathrm{~mm}$ (Total length). $\mathrm{N}=1$. 


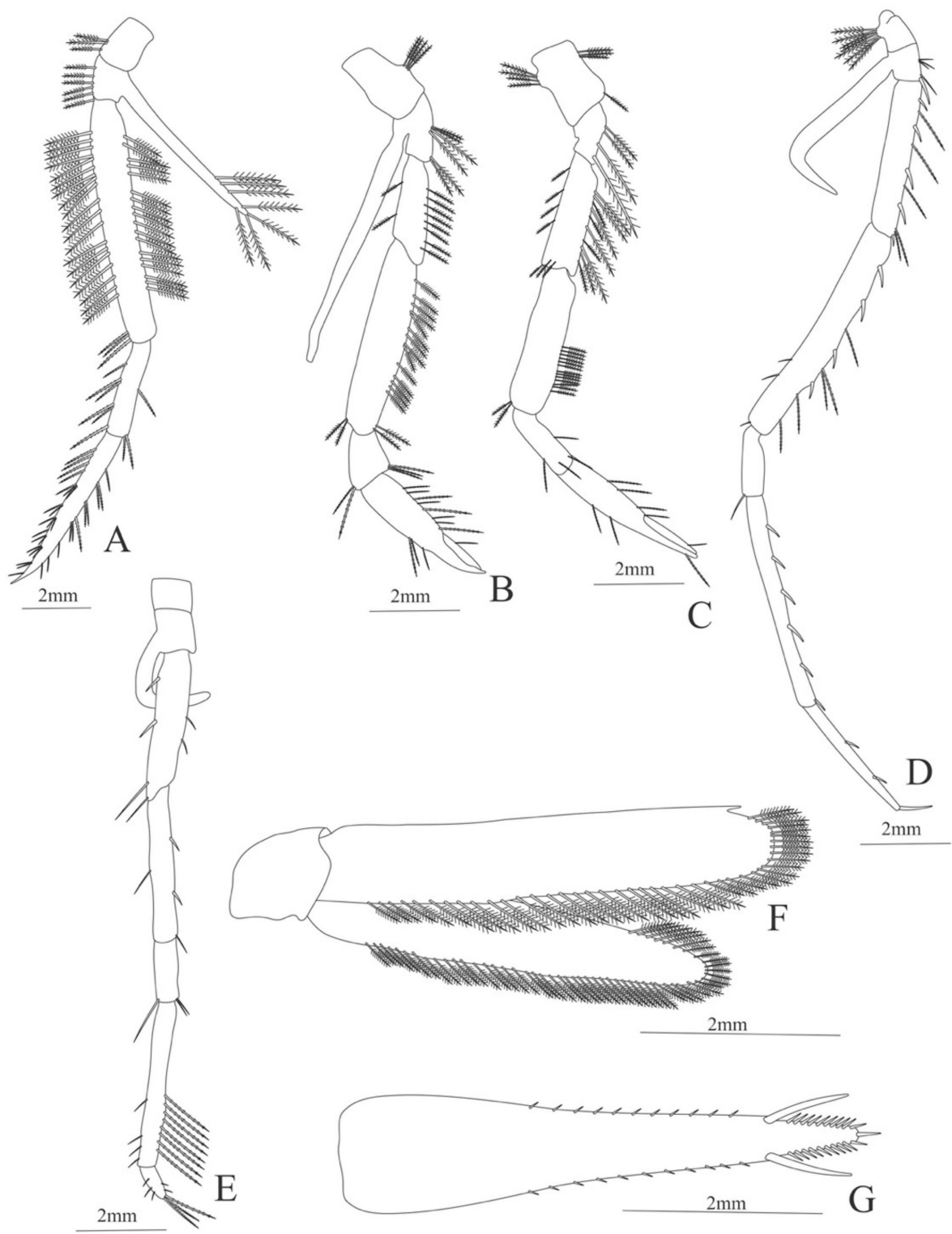

Figure 18. Systellaspis braueri: (A) third maxilliped; (B) first pereopod; (C) second pereopod; (D) fourth pereopod; (E) fifth pereopod; (F) telson; (G) uropods.

\footnotetext{
Pandalidae Haworth, 1825

Heterocarpus ensifer A. Milne-Edwards, 1881

(Figures 19 and 20)
}

Carapace (Figure 19A). Rostrum large armed dorsally with 21 spines and 9 ventral spines, one spine near the posterior margin of the carapace, suborbital spine strong.

Pleon (Figure 19A) with a pointed projection on segments 3 and 4. Other segments without spines or setae. Pleopods 1-4 missing in the specimen, pleopod 5 without setae.

Antennule (Figure 19B). Peduncle 3-segmented, article 1 the longest, slender, with 9 plumose setae in both margins, article 2 with 2 plumose setae and article 3 , the smallest, with 3 plumose setae and with two flagella distally.

Antenna (Figure 19C). Protopod 3-segmented, article 1 and 2 unarmed, article 3 with 5 small spines and a flagellum; exopod flattened, subtriangular, with a slender and pointed projection on its distal region and 13 pointed projections on the superior margin and 64 plumose setae in the inferior margin.

Mandible (Figure 19D, E) without palp, right mandible with 6 teeth and left mandible with 4 teeth. 
Maxillule (Figure 19F). Coxal endite with 19 conical serrulated setae; basial endite with 12 conical serrulated setae; protopod with 4 plumose setae.

Maxilla (Figure 19G). Coxal endite bilobed with 17 plumose plus 2 serrated and one plumose setae; basial endite bilobed with 10 plus 12 plumose setae; endopod with $8(2+2+1+1+2)$ plumose setae, segmentation not well defined; scaphognathite margin with 143 plumose setae.

First maxilliped (Figure 19H). Coxa with 7 plumose setae; basis with 23 plumose setae; exopod with 50 plumose setae; endopod 4-segmented, armed with 22 setae, five of them plumose all the others simple.

Second maxilliped (Figure 19I). Coxa with one plumose seta; basis with 10 plumose plus 4 serrulated setae; endopod 5-segmented with 4, 3, 2, 4, 8 plumose setae, except the first and the last articles which have one serrated seta each; exopod armed distally with 17 plumose setae.

Third Maxilliped (Figure 19J). Coxa with 3 simple setae; basis with 9 simple setae; endopod 4-segmented with 13, 9, 21, 2 simple setae; exopod armed distally with 6 plumose setae.

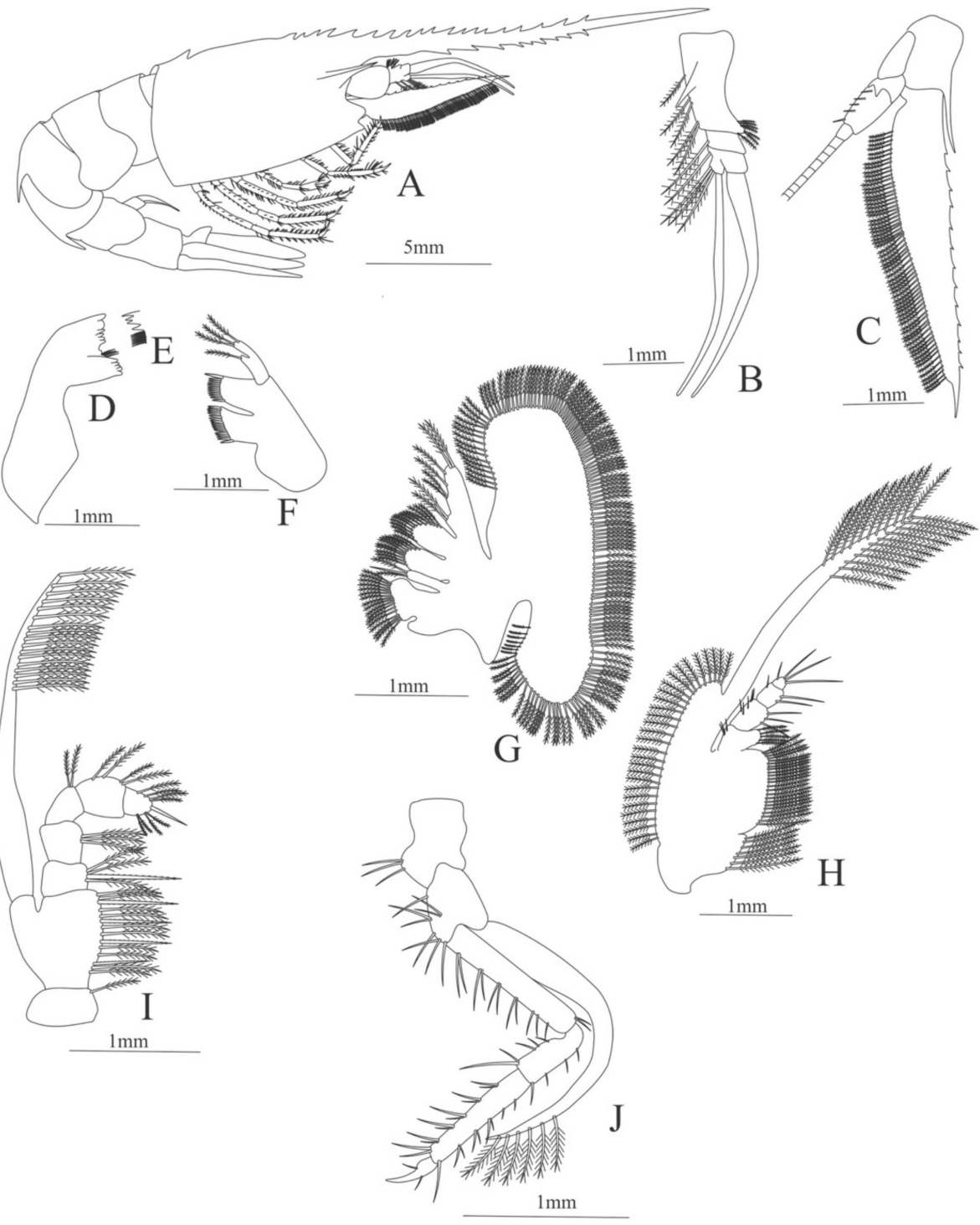

Figure 19. Heterocarpus ensifer: (A) lateral view; (B) antennule; (C) antenna; (D) right mandible; (E) left mandible (cutting edge); (F) maxillule; (G) maxilla; (H) first maxilliped; (I) second maxilliped; (J) third maxilliped. 
First pereopod (Figure 20A). Coxa without setae; Basis with 5 simple setae; endopod 5 -segmented with 5, 8, 14, 27, 4 simple setae; exopod armed distally with 10 plumose setae.

Second pereopod (Figure 20B). Coxa without setae; basis with 5 simple setae; endopod 5 -segmented with 10, 8, 8, 7, 3 simple setae; exopod armed distally with 6 plumose setae.

Third pereopod (Figure 20C). Coxa without setae; basis with 4 setae; endopod 5segmented with 5, 21, 7, 23, 5 simple setae; exopod armed distally with 6 plumose setae.

Fourth pereopod (Figure 20D). Coxa without setae; basis with 2 simple setae; endopod 5 -segmented with 9 (6 simple setae plus 3 spines), 17 (10 simple setae plus 7 spines), 7, 27, 5 simple setae; exopod armed distally with 7 plumose setae.

Fifth pereopod (Figure 20E). Coxa with one simple setae; Basis with 6 simple setae; endopod 5-segmented with 11 ( 3 spines plus 8 simple setae), 14, 7, 34, 8 simple setae.

Uropod (Figure 20F). Endopod and exopod well developed, exopod with 84 plumose setae and endopod with 90 plumose setae.

Telson (Figure 20G) enlarged, subtriangular, with 4 pairs of lateral spines and posterior margin bearing row of 5 diminute spines and one pairs of spines on outer margin.
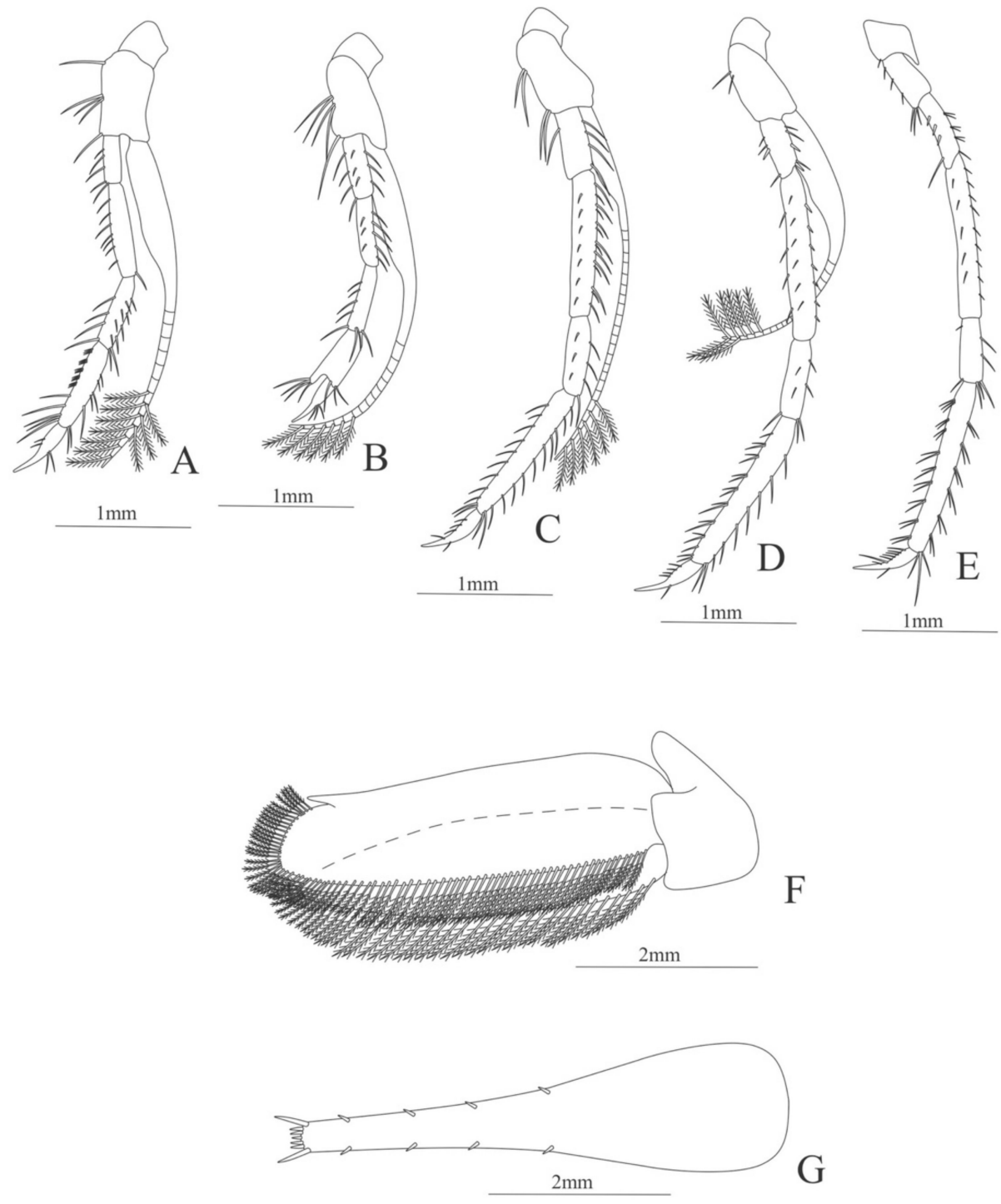

Figure 20. Heterocarpus ensifer: (A) first pereopod; (B) second pereopod; (C) third pereopod; (D) fourth pereopod; (E) fifth pereopod; (F) uropods; (G) telson. 
Material examined: Gulf of Mexico: HBG 7584, R/V Point Sur, DP04-09Aug16-MOC10SE3N-065-N5, from 26.9997, -86.9912 to 26.9903, -87.1491; 9 August 2016, 199.2-5 m, MOCNESS plankton net, H. Bracken-Grissom, coll.

Decapodite. Size: $15 \mathrm{~mm}$ (Carapace length); $58 \mathrm{~mm}$ (Total length). $\mathrm{N}=1$.

Carapace (Figure 21A). Rostrum long and unarmed, slender, longer than carapace; antennal spine small; anteroventral margin bearing 1 strong pterygostomian spine; eyes pedunculate.

Pleon (Figure 21A) with 6 somites, no spines or setae. Pleopods 1-4 missing in the specimen, pleopod 4 well developed.

Antennule (Figure 21B). Peduncle 3-segmented, article 1, the longest, armed with 27 (15 outer plus 12 inner) plumose setae and one spine, article 2 with 9 (6 outer plus 3 inner) plumose setae and article 3 with 5 outer plumose setae and two flagella distally.

Antenna (Figure 21C). Protopod 3-segmented with a flagellum; exopod flattened with 71 plumose setae and a pointed process distally.

Mandible. Palp absent; right and left slightly asymmetrical, right incisor with 3 terminal teeth (Figure 21D); left incisor with 4 teeth (Figure 21E).

Maxillule (Figure 21F). Coxal endite with 12 conical serrate setae; basial endite with 7 conical serrate setae and 4 simple setae; endopod unsegmented, with $1+3$ serrated setae.

Maxilla (Figure 21G). Coxal endite bilobed with 12 plumose plus 3 simple setae; basial endite bilobed with $4+7$ simple setae; endopod unsegmented with $6(2+2+2)$ simple setae; scaphognathite margin with 120 plumose setae.

First maxilliped (Figure 21H). Coxa with 3 large plumose plus 3 simple setae; basis with 12 plumose setae; endopod 4-segmented with 6 (5 simple plus one conical serrate) 3 (2 simple plus one conical serrate), 2 (one simple pus one conical serrate), 3 simple setae; endopod armed with 21 plumose setae and exopod armed distally with 12 plumose setae.

Second maxilliped (Figure 21I). Coxa with one plumose seta; basis with 11 (4 simple plus 4 plumose plus 3 conical serrated) setae; endopod 5-segmented with 3 (one conical serrated plus 2 simple), 2 simple, 1 simple, 7 simple, 8 (5 conical serrated and 3 simple) setae; exopod unarmed.

Third maxilliped (Figure 21J). Coxa without setae; basis with 5 simple setae; endopod 5-segmented with 2 simple, 19 (13 simple setae plus 6 spines), 11 simple, 12 simple, 0 setae; exopod armed with 9 plumose setae.

First pereopod (Figure 22A). Coxa and basis unarmed; endopod 5-segmented with 5, 14 (7 spines plus 7 simple setae), 12 (4 spines plus 8 simple setae), 9 simple, 0 setae; exopod unarmed.

Second pereopod (Figure 22B). Coxa unarmed, basis with 2 simple setae; endopod 5-segmented with 4 spines, 11 (6 spines plus 5 simple setae), 19 (6 spines plus 13 simple setae), 2 simple setae, 0 setae; exopod unarmed.

Third pereopod (Figure 22C). Basis armed with 2 simple setae; endopod 5-segmented with 6 simple setae, 18 spines, 5 spines, 19 ( 9 spines plus 10 setae), 0 setae; exopod unarmed.

Fourth pereopod (Figure 22D). Coxa and basis unarmed; endopod 5-segmented with 3 spines, 19 (9 spines plus 10 simple setae), 5 (4 spines plus one simple seta), 9 (7 spines plus 2 simple setae), 0 simple setae; exopod unarmed.

Fifth pereopod (Figure 22E). Coxa unarmed, basis with 2 simple setae; endopod 5-segmented with 4 simple setae, 21 (10 spines plus 11 simple setae), 8 (5 spines plus 3 simple setae), 15 (9 spines plus 6 simple setae), 0 simple setae; exopod absent. 


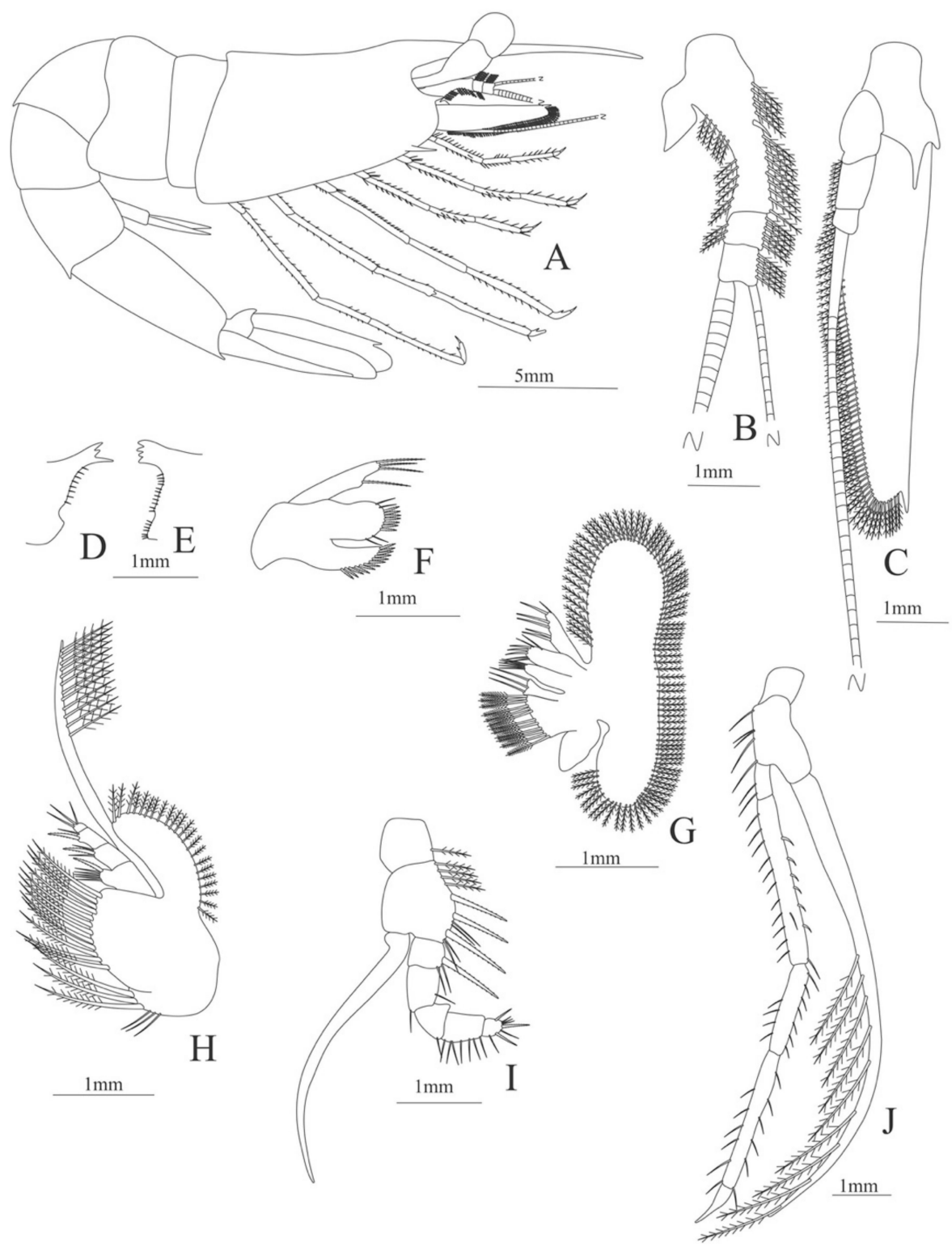

Figure 21. Plesionika edwardsii: (A) lateral view; (B) antennule; (C) antenna; (D) left mandible (cutting edge); (E) rigth mandible (cutting edge); (F) maxillule; (G) maxilla; (H) first maxilliped; (I) second maxilliped; (J) third maxilliped.

Uropods (Figure 22F). Endopod well developed with 96 plumose setae; exopod, with 84 plumose setae

Telson (Figure 22G) elongate, subtriangular, with three pairs of lateral spines; distally with one central large spine and 3 pairs of small spines and one spine on each corner.

Plesionika ensis (A. Milne-Edwards, 1881)

(Figures 23 and 24)

Material examined: Gulf of Mexico: HBG6825, R/V Point Sur, DP04-07Aug16-MOC10SW4N-061-N0, 26.8887, -89.0389, and 26.9936, -88.9987, 7 August 2016, 1500.8-NA m, MOCNESS plankton net, H. Bracken-Grissom, coll. Gulf of Mexico: HBG7845, R/V Point Sur, DP05-10May17-MOC10-B175D-096-N2, 28.9922 and -87.4786, 29.0336 and -87.6491, 10 May 2017, 1199-995 m, MOCNESS plankton net, L. Timm, coll. Gulf of Mexico: HBG7995, R/V Point Sur, DP05-06May17-MOC10-B287N-089-N3, 28.1179 and -87.3899, 28.0467 and -87.5559, 6 May 2017, 1000-600 m, MOCNESS plankton net, L. Timm, coll. Gulf of Mexico: 
HBG9264, R/V Point Sur, DP06-20Jul18-MOC10-B175N-102-N0, 29.0045 and -87.4658, 20 July 2018, 600 m, MOCNESS plankton net, H. Bracken-Grissom, coll.

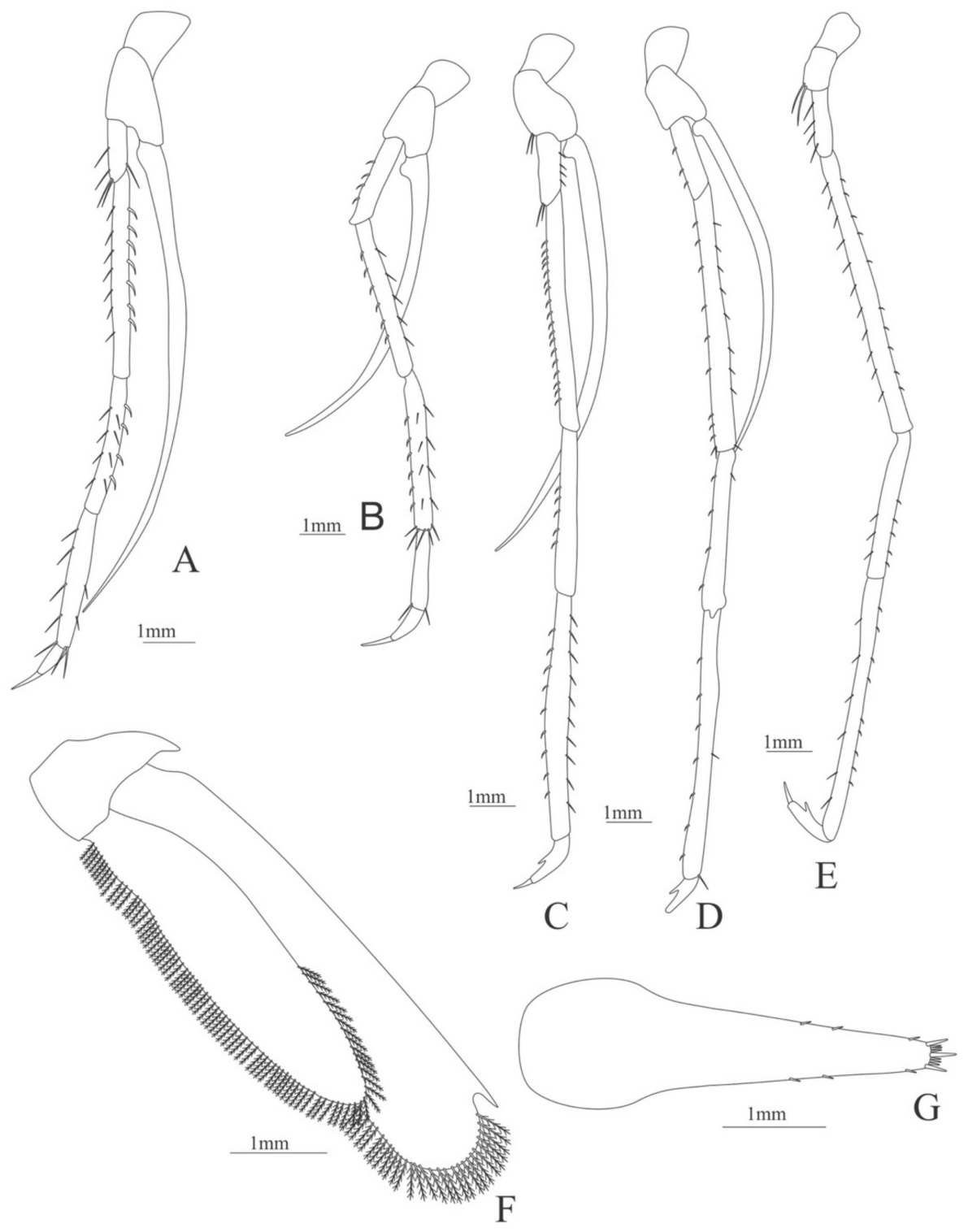

Figure 22. Plesionika edwardsii: (A) first pereopod; (B) second pereopod; (C) third pereopod; (D) fourth pereopod; (E) fifth pereopod; (F) telson; (G) Uropods.

Juvenile. Size. $12 \mathrm{~mm}$ (Carapace length); $36 \mathrm{~mm}$ (Total length). $\mathrm{N}=4$.

Carapace (Figure 23A). Rostrum long, slender, with 3 basal spines, slightly curved upwards and longer than antennular peduncle; antennal spine present; eyes pedunculate.

Pleon (Figure 23A) with 6 somites, no spines or setae. Pleopods 3-4 missing in the specimen, pleopods $1-2$ and 5 well developed.

Antennule (Figure 23B). Peduncle 3-segmented, article 1 with 16-18 plumose setae, article 2 with 9 plumose setae and article 3 with two flagella.

Antenna (Figure 23C). Protopod 3-segmented; article 1 with two sharp projections, article 2 with 4 simple setae and article 3 with 5 simple setae. exopod flattened with 63-66 plumose setae and a pointed process distally.

Mandible (Figure 23D). Palp 3-segmented, article 1 unarmed, article 2 with 3 simple setae and article 3 with 16 simple setae, right incisor with 5 terminal teeth. 
Maxillule (Figure 23E). Coxal endite with 10-12 simple setae plus 10-18 serrulate setae; basial endite with 15-18 simple setae plus 10-12 conical setae; endopod unsegmented, with 6 simple setae plus one plumose seta; exopod absent.

Maxilla (Figure 23F). Coxal endite with 12-16 plumose setae; basial endite bilobed both armed with 28-30 and 28-32 serrulated setae respectively; endopod unsegmented with $4(1+1+2)$ plumose setae; scaphognathite margin with 89-93 plumose setae.

First maxilliped (Figure 23H). Coxa with 15-17 serrulate setae; basis endite with 43-52 serrulate setae; endopod with 28-32 plumose setae; exopod unsegmented, armed distally with 10-13 plumose setae.

Second maxilliped (Figure 23G). Coxa with 4 serrulated setae; basis with 14 serrulated setae; endopod 5-segmented with 1 plumose seta, 6 plumose setae and 4-5, 11-20, 5-10 serrulated setae; exopod armed with 8-10 plumose setae.

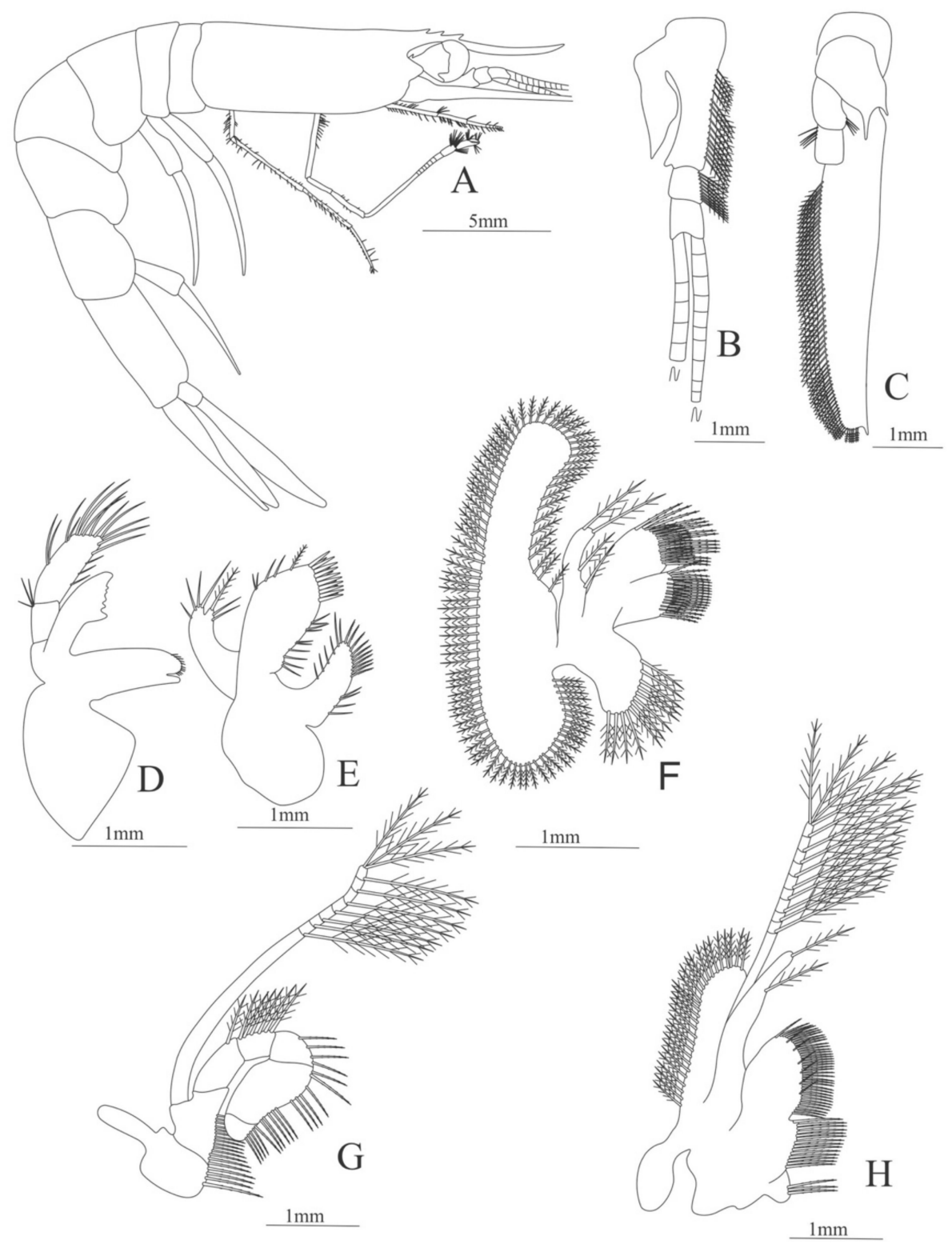

Figure 23. Plesionika ensis: (A) lateral view; (B) antennule; (C) antenna; (D) mandible; (E) maxillule; (F) maxilla; (G) first maxilliped; (H) second maxilliped.

Third maxilliped (Figure 24A). Coxa without setae; basis with 7 simple setae; endopod 3-segmented with $24,13,12$, simple setae; exopod unsegmented, armed distally 16 simple setae. 
First pereopod missing in the specimen.

Second pereopod (Figure 24B). Coxa and basis without setae; endopod 5-segmented with 14, 0, 7, 0 (with 8 divisions), 24, 6 simple setae.

Third and fourth pereopods missing in the specimen.

Fifth pereopod (Figure 24C). Coxa without setae, basis with 10 simple setae, endopod 5-segmented with 13, 26, 26, 26, 3 simple setae.

Uropod (Figure 24D). Endopod well developed with 67-76 plumose setae; exopod, with 92-97 plumose setae.

Telson (Figure 24E) elongate, subtriangular, with 3 pairs of lateral spines and 2 pairs of distal spines.
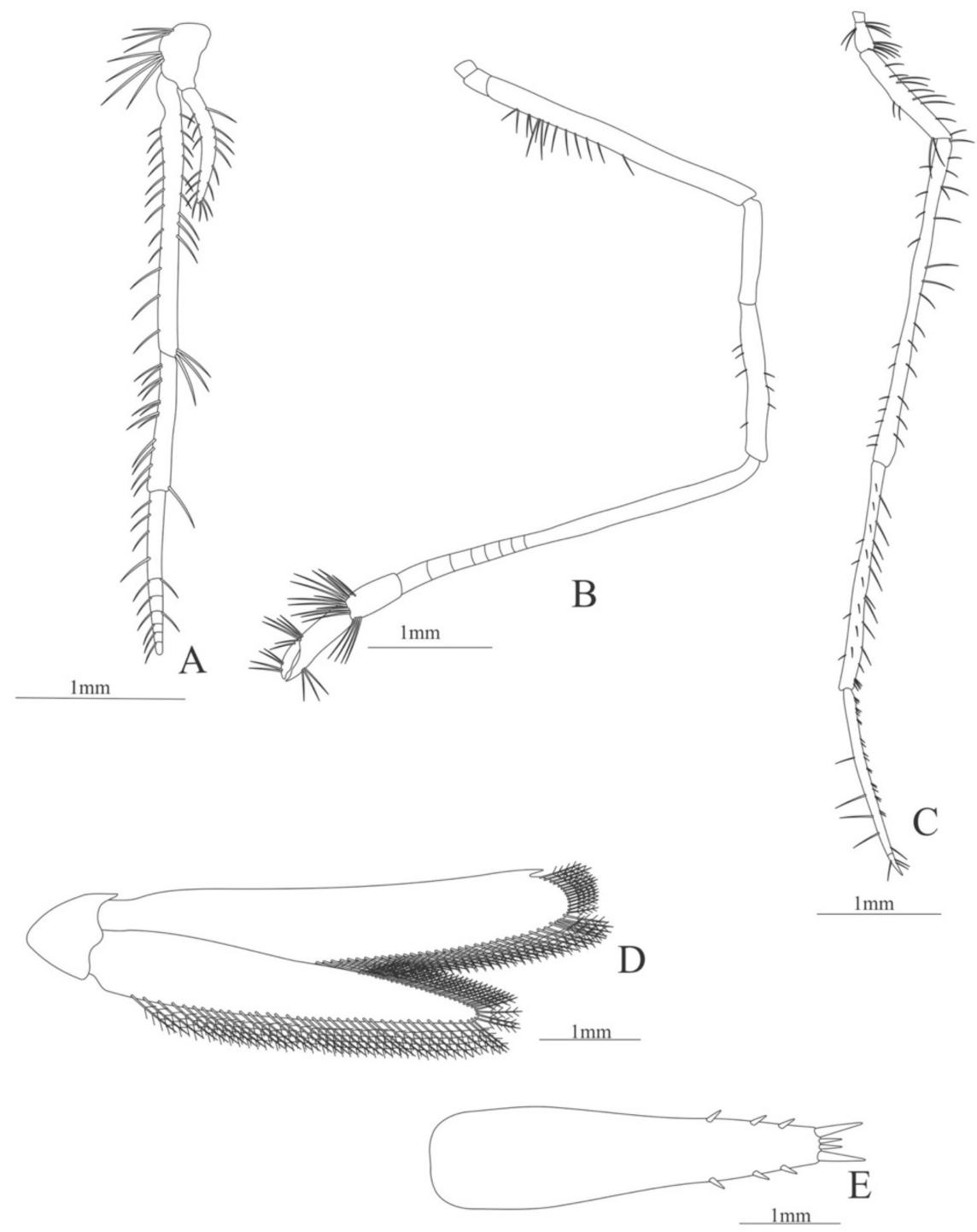

Figure 24. Plesionika ensis: (A) third maxilliped; (B) second pereopod; (C) fifth pereopod; (D) Uropods; (E) telson.

Aristeidae Wood-Mason in Wood-Mason and Alcock, 1891 Hemipenaeus Spence Bate, 1881

Hemipenaeus carpenteri Wood-Mason in Wood-Mason and Alcock, 1891

(Figures 25 and 26)

Material examined: Gulf of Mexico: HBG 6846, R/V Point Sur, DP04-09Aug16-MOC10SE3N-065-N3, 26.9997, -86.9912 and 26.9909, -87.1491, 9 August 2016, 1000.5-3 m, MOCNESS plankton net, H. Bracken-Grissom, coll. 
Mysis. Size. $6 \mathrm{~mm}$ (Carapace length); $16 \mathrm{~mm}$ (Total length). $\mathrm{N}=1$.

Carapace (Figure 25A) with two lateral swollen process near the posterior margin, rostrum long, extend until the end of the article 1 of the antennule, slightly curved; anteroventral margin bearing 1 strong pterygostomial spine and 1 postorbital spine; eyes pedunculate.

Pleon (Figure 25A) with 6 somites, no spines or setae. Pleopods 1-5 without setae.

Antennule (Figure 25B). Peduncle 3-segmented, article 1 the longest, slender, with 21 plumose setae in both margins, article 2 with 11 plumose setae in both margins and article 3 , the smallest with 5 plumose setae and two flagella distally. Flagella short, same size, inner 5-segmented and outer 6-segmented with plumose setae.

Antenna (Figure 25C). Protopod 3-segmented with a flagellum; exopod with 66 plumose setae.

Mandible (Figure 25D). Palp 3-segmented, article 1 unarmed, article 2 with 5 simple setae and article 3 with 10 simple setae.

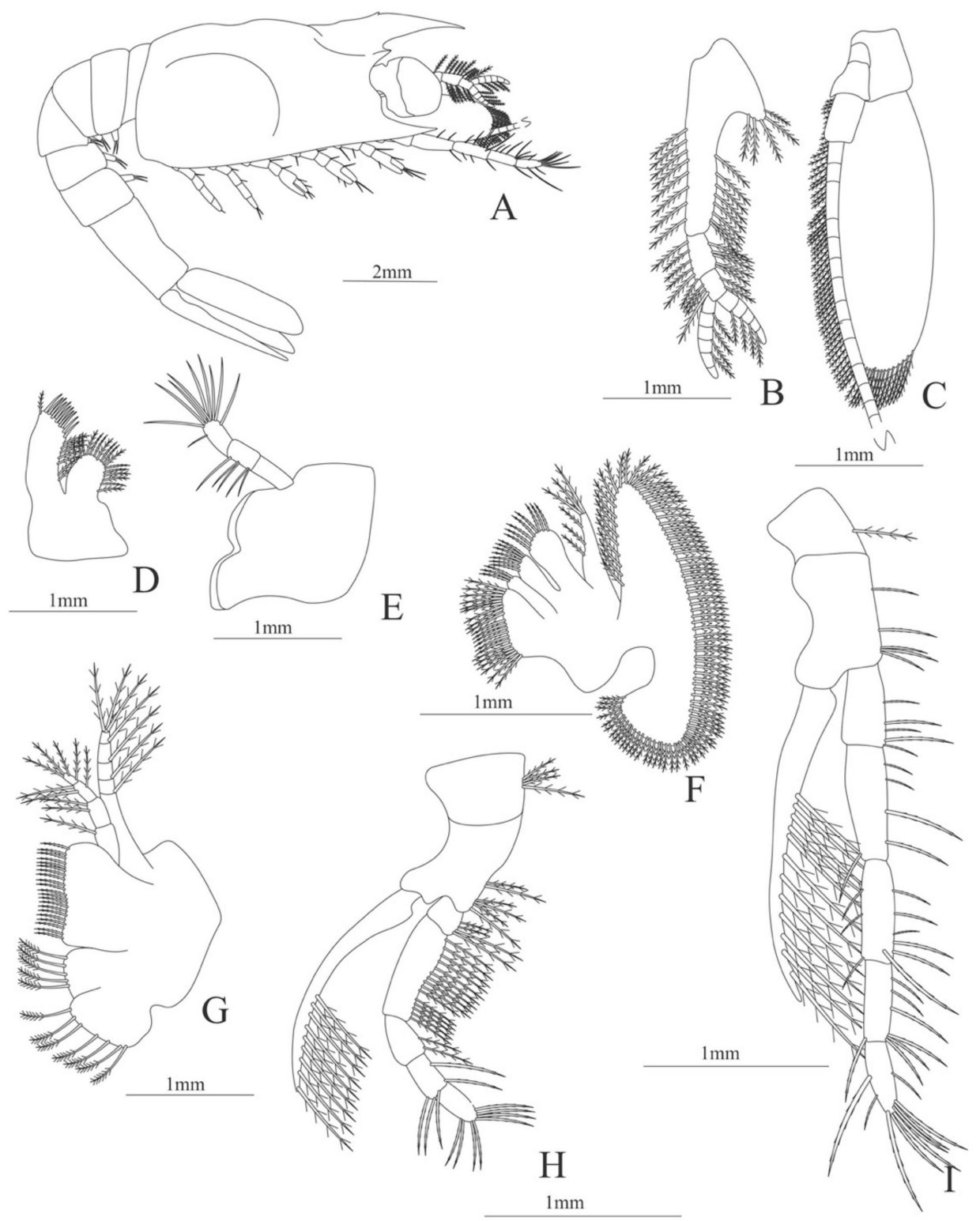

Figure 25. Hemipenaeus carpenteri: (A) lateral view; (B) antennule; (C) antenna; (D) maxillule; (E) mandible; (F) maxilla; (G) first maxilliped; (H) second maxilliped; (I) third maxilliped. 
Maxillule (Figure 25E). Coxal endite with 15 (10 serrated plus 5 plumose) setae; basial endite with 11 conical setae and one plumose subdistal setae.

Maxilla (Figure 25F). Coxal endite bilobed with 21 (15 plumose plus 6 serrated) setae; basial endite bilobed with 15 (7 plus 8 serrated) setae; endopod with $6(1+1+1+3)$ plumose setae, segmentation not well defined; scaphognathite margin with 89 plumose setae.

First maxilliped (Figure 25G). Coxa with two endites and $12(5+7)$ plumose setae; basis with 21 serrated setae; endopod 4-segmented with 1, 2, 4, 3 plumose setae; exopod unsegmented, armed with 7 plumose setae.

Second maxilliped (Figure 25H). Coxa with 4 plumose setae; basis with 6 plumose setae; endopod 5-segmented with 4, 15, 2, 5, 9 plumose setae, except the last two articles which have serrated setae; exopod unsegmented, armed distally with 9 long plumose natatory setae.

Third maxilliped (Figure 25I). Coxa with 1 plumose seta; basis with 5 serrated setae; endopod 5-segmented with 5, 5, 9, 7, 9 serrated setae; exopod unsegmented, armed distally with 12 long plumose natatory setae.

First pereopod (Figure 26A). Basis with 2 simple setae; endopod 5-segmented with 1, 1, 1, 2, 3 setae; exopod armed distally with 10 plumose setae.

Second pereopod (Figure 26B). Basis unarmed; endopod 5-segmented with 2, 1, 1, 3, 2 setae; exopod armed distally with 14 plumose setae.

Third pereopod (Figure 26C). Basis unarmed; endopod 5-segmented with 0, 1, 1, 1, 4 ( 2 inner +2 terminal) setae; exopod armed distally with 11 plumose setae.

Fourth pereopod (Figure 26D). Basis unarmed; endopod 5-segmented with 0, 1, 1, 0, 2 setae; exopod armed distally with 9 plumose setae.

Fifth pereopod (Figure 26E). Basis unarmed; endopod 5-segmented with 0, 1, 0, 0 , 1 setae; exopod armed distally with 12 plumose setae.

Uropod (Figure 26F). Endopod and exopod well developed, both missing setae.

Telson (Figure 26G) enlarged, subrectangular, with two pairs of lateral spines and posterior margin bearing row of 4 pairs of minute spinules and 2 pairs of spines on outer margin.

Hemipenaeus carpenteri Wood-Mason in Wood-Mason and Alcock, 1891 (Figures 27 and 28)

Material examined: Gulf of Mexico: HBG 6854, R/V Point Sur DP04-08Aug16-MOC10SE1N-063-N5, 26. 9878, -87.9494, and 27.0591, -88.0856, 8 August 2016, 202.7-5 m, MOCNESS plankton net, H. Bracken-Grissom, coll. Gulf of Mexico: HBG 7552, R/V Point Sur DP04-11Aug16-MOC10-SW3D-068-N5, 27. 0122, -88.4618, and 26.9255, -88.5970, 11 August 2016, 199.8-5 m, MOCNESS plankton net, H. Bracken-Grissom, coll. Gulf of Mexico: HBG 7867, R/V Point Sur DP05-11May17-MOC10-B175D-098-N0, 26. 9690, -87.4396, 11 May 2017, 1500-0 m, MOCNESS plankton net, L. Timm, coll.

Mysis. Size: $9 \mathrm{~mm}$ (Carapace length); $21 \mathrm{~mm}$ (Total length). $\mathrm{N}=3$.

Carapace (Figure 27A) with two lateral swollen process near the posterior margin, rostrum long, extend until the end of the article 1 of the antennule; orbital spine as a projected bump; antennal spine is a small bump; anteroventral margin bearing 1 strong and curved pterygostomial spine; eyes pedunculate. 

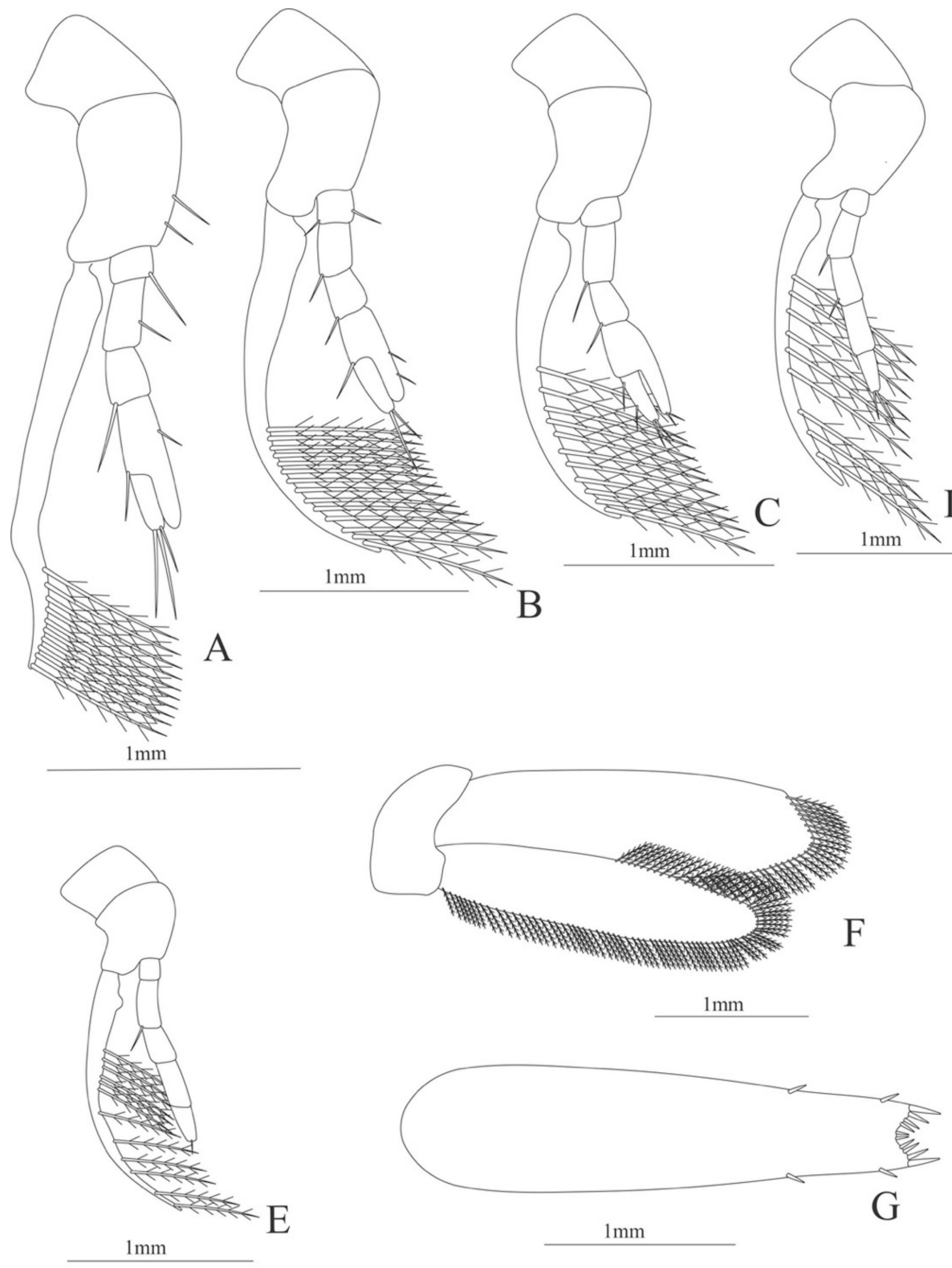

Figure 26. Hemipenaeus carpenteri: (A) first pereopod; (B) second pereopod; (C) third pereopod; (D) fourth pereopod; (E) fifth pereopod; (F) uropods; (G) telson.

Pleon (Figure 27A) with 6 somites, no spines or setae. Pleopods without setae.

Antennule (Figure 27B). Peduncle 3-segmented, article 1 the longest, slender, with 3 simple and 9-12 plumose setae, article 2 also with 6 plumose setae in the outer margins and article 3 , the smallest with 3 lateral simple setae and two distal flagella, outer flagella unarmed and inner flagella with 4 lateral simple setae and 2 distal setae.

Antenna (Figure 27C). Protopod 3-segmented with a flagellum; exopod with 62-69 plumose setae.

Mandible (Figure 27D). Palp 2-segmented, article 1 with 7-10 plumose setae and article 2 with $13-15$ plumose setae (7 lateral plus 6 terminal).

Maxillule (Figure 27E). Coxal endite with 7 curved conical spines and 1 subterminal simple setae; basial endite with 11 plumose setae.

Maxilla (Figure 27F). Coxal endite bilobed with $6+8$ simple setae; basial endite bilobed with $6+8$ plumose setae; endopod with $5(2+1+2)$ plumose setae, segmentation not well defined; scaphognathite margin with 89-92 plumose setae. 
First maxilliped (Figure 27G). Coxa with 8-10 plumose setae; basis with 14-18 plumose setae in the margin and 10-12 simple setae; endopod unsegmented with $11(4+2+1+1+3)$ simple setae; exopod unsegmented, armed with 8 plumose setae.

Second maxilliped (Figure 27H). Coxa without setae; basis with 5-8 simple setae; endopod 5-segmented with 5-6, 5-7, 5, 7-12, 8-9 serrulated setae; exopod unsegmented, armed distally with 7-9 plumose setae.

Third maxilliped (Figure 27I). Coxa without setae; basis with 4 simple setae; endopod 5-segmented with 5, 3, 4, 6, 8, all simple setae; exopod unsegmented armed distally with 5-7 plumose setae.

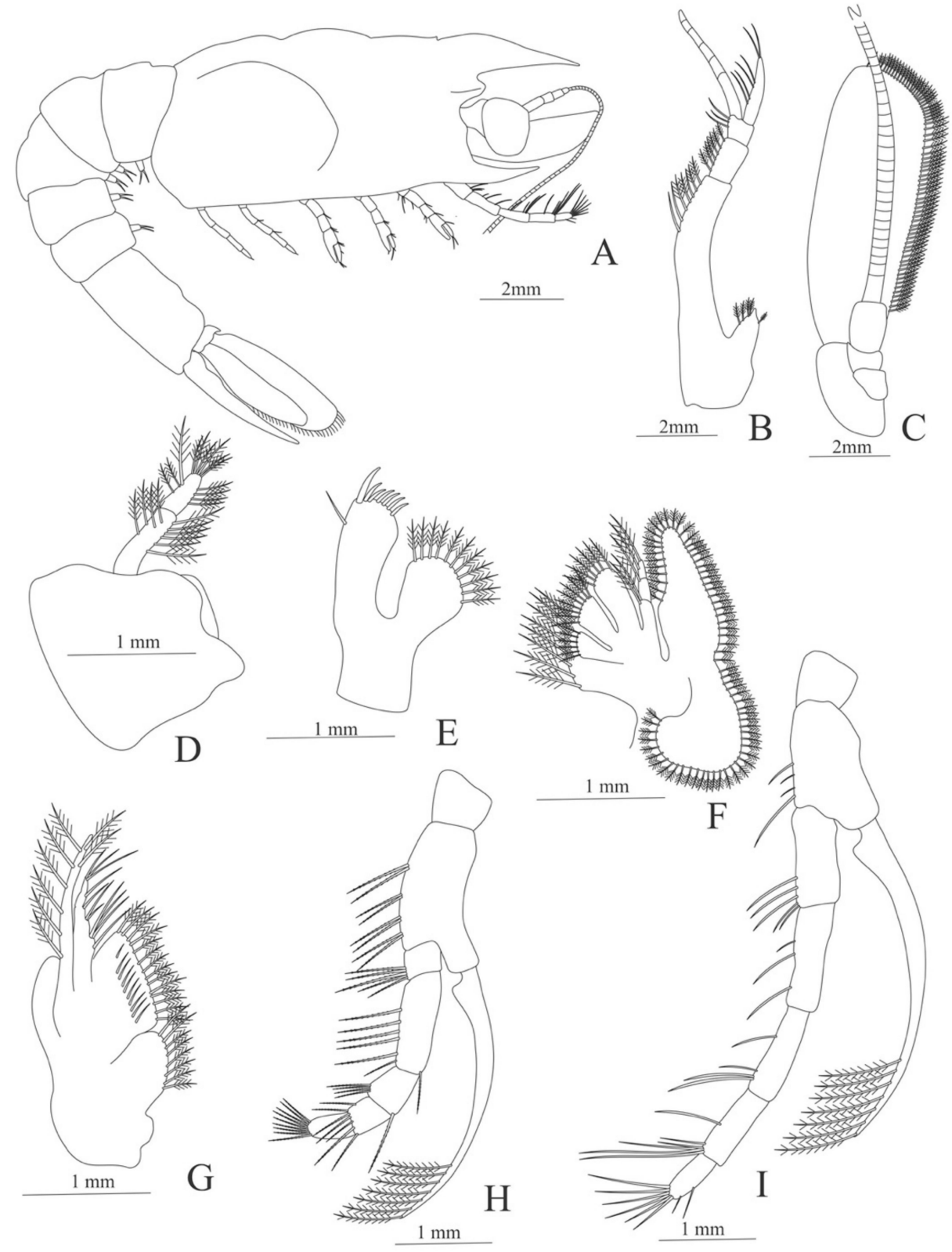

Figure 27. Hemipenaeus carpenteri: (A) lateral view; (B) antennule; (C) antenna; (D) mandible; (E) maxillule; (F) maxilla; (G) first maxilliped; (H) second maxilliped; (I) third maxilliped.

First pereopod (Figure 28A). Coxa and basis without setae; endopod 5-segmented with 0, 0, 2, 3, 2 setae; exopod unsegmented, armed with 7-10 plumose natatory setae.

Second pereopod (Figure 28B). Coxa without setae, basis with 2 simple setae; endopod 5-segmented with 3, 2, 3, 1, 4 simple setae; exopod unsegmented, armed with 7-9 plumose natatory setae. 
Third pereopod (Figure 28C). Coxa and basis without setae; endopod 5-segmented with $0,1,1,3,3$ simple setae; exopod unsegmented, armed with 9-12 long, plumose natatory setae.

Fourth pereopod (Figure 28B). Coxa and basis without setae; endopod 5-segmented with $0,1,1,0,1$ simple seta; exopod unsegmented, armed with 11-12 long plumose natatory setae.

Fifth pereopod (Figure 28A). Coxa and basis unarmed; endopod 5-segmented with 0 , $0,0,0,1$ simple setae; exopod unsegmented armed with 10-12 long plumose natatory setae.

Uropod (Figure 28F). Endopod well developed with 80-85 plumose setae; exopod with 60-63 plumose setae.

Telson (Figure 28G) elongate, subtriangular, with 3 pairs of lateral spines and 5 pairs of distal spines.
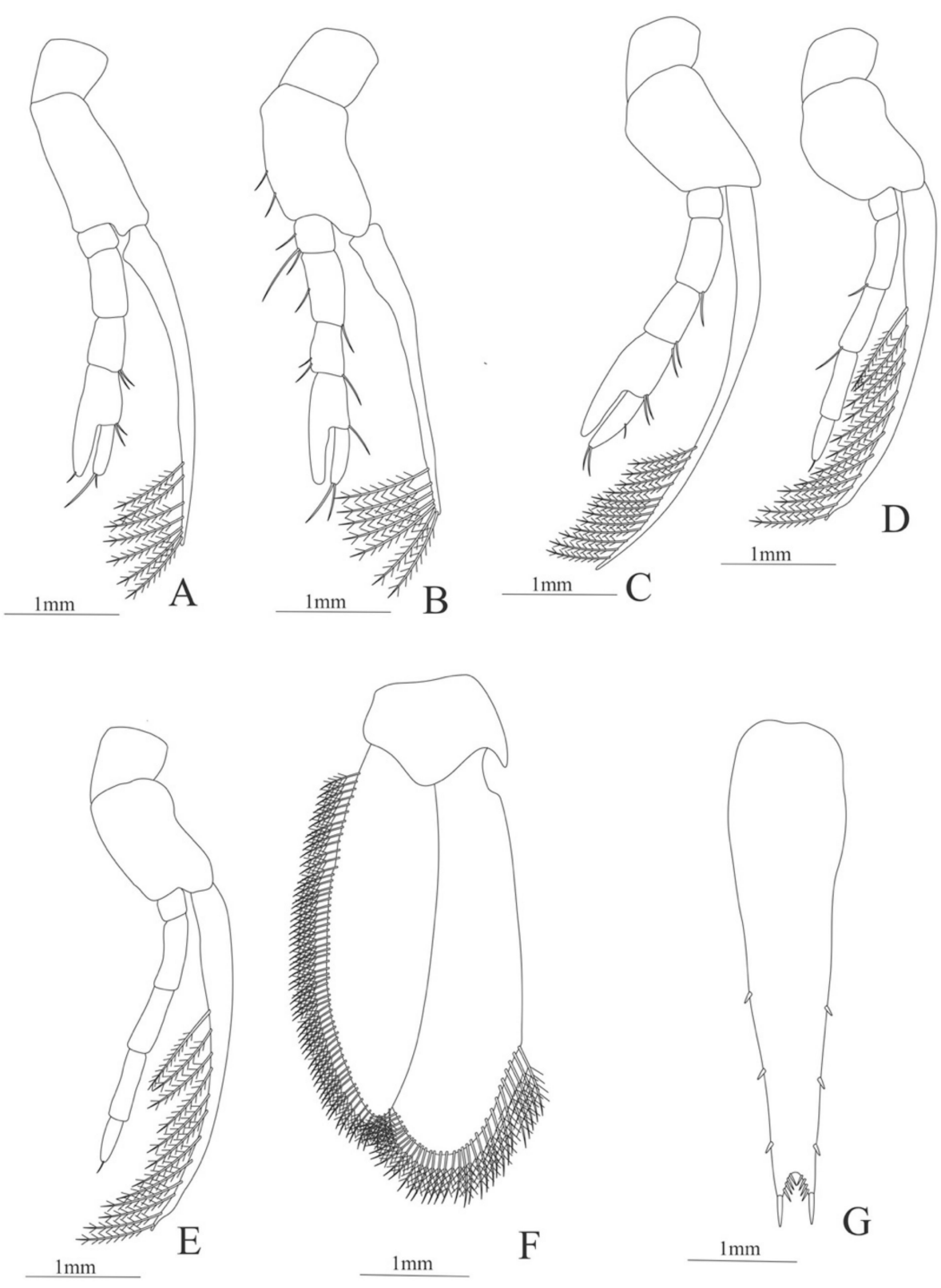

Figure 28. Hemipenaeus carpenteri: (A) first pereopod; (B) second pereopod; (C) third pereopod; (D) fourth pereopod; (E) fifth pereopod; (F) uropods; (G) telson. 
Cerataspis monstrosus (Gray, 1828)

(Figures 29 and 30)

Material examined: Gulf of Mexico: HBG 9204, R/V Point Sur, DP06-24Jul18-MOC10B251N-106-N1, 28.5401, -88.4711 and 28.5122, -88.6337, 24 July 2018, 1201-1475 m, MOCNESS plankton net, H. Bracken-Grissom, coll.

Mysis. Size. $6 \mathrm{~mm}$ (Carapace length); $20 \mathrm{~mm}$ (Total length). $\mathrm{N}=1$.

Carapace (Figure 29A) with two small lateral swollen process near the posterior margin, rostrum long, extend until the end of the article 1 of the antennule, slightly curved; anteroventral margin bearing one small pterygostomian spine; eyes pedunculate.

Pleon (Figure 29A) with 6 somites, small spine on dorsal third somite. Pleopods 4-5 missing in the specimen, pleopods $1-3$ without setae.

Antennule (Figure 29B). Peduncle 3-segmented, article 1 the longest, slender, with 35 plumose setae in both margins, article 2 with 18 plumose setae in both margins and article 3 , the smallest with 6 plumose setae and two flagella distally.

Antenna (Figure 29C). Protopod 2-segmented with a flagellum; exopod with 86 plumose setae and a pointed process distally.

Mandible (Figure 29D). Palp 4-segmented, articles 1- 3 unarmed, article 4 with 7 simple setae.

Maxillule (Figure 29E). Coxal endite with 13 conical setae; basial endite with 15 conical setae, protopod with two simple setae.

Maxilla (Figure 29F). (Damaged in the specimen). Coxal endite and the bilobed basial endite bilobed unarmed; endopod with $5(1+2+2)$ simple setae, segmentation not well defined; scaphognathite margin with 38 plumose setae.

First maxilliped (Figure 29G). (Damaged in the specimen). Coxa and basis unarmed; endopod unsegmented with 17 plumose setae; exopod 4 segmented with 0, 2,14, 8 plumose setae.

Second maxilliped (Figure 29H). (Damaged in the specimen). Coxa and basis unarmed; endopod 4-segmented with 3, 1, 1, 2 simple setae; exopod unsegmented and unarmed.

Third maxilliped missing in the specimen.

First pereopod (Figure 29I). Coxa and basis unarmed; endopod 5-segmented with 2, 1, 0, 0, 0 setae; exopod unsegmented and unarmed.

Second pereopod (Figure 30A). Coxa unarmed; Basis with 3 setae; endopod 5-segmented with 3, 0, 4, 0, 0 setae; exopod unsegmented and unarmed.

Third pereopod (Figure 30B). Coxa and basis unarmed; endopod 5-segmented with 2, 0, 0, 0, 0 setae; exopod unsegmented and unarmed.

Fourth pereopod (Figure 30C). (Damaged in the specimen) Coxa and basis unarmed; endopod 5-segmented with 3, 0, 1, 0, 0 setae; exopod unsegmented and unarmed.

Fifth pereopod (Figure 30D). (Damaged in the specimen). Coxa and basis unarmed; endopod 5-segmented with 2, 5, 0, 0, 0 setae; exopod unsegmented and unarmed. 


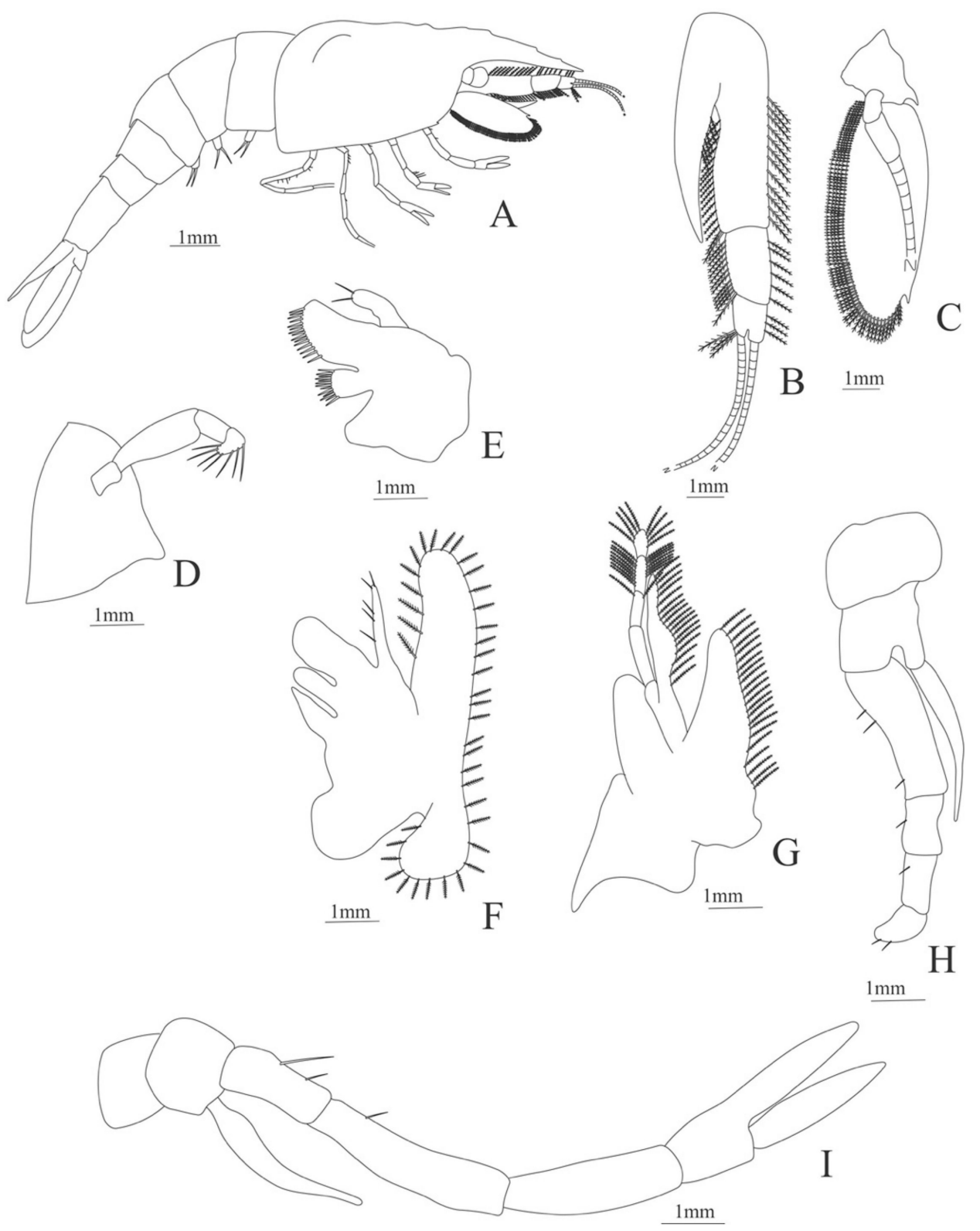

Figure 29. Cerataspis monstrosus: (A) lateral view; (B) antennule; (C) antenna; (D) mandible; (E) maxillule; (F) maxilla; (G) first maxilliped; (H) second maxilliped; (I) first pereopod.

Uropod (Figure 30E). Endopod well developed with 96 plumose setae; exopod with 120 plumose setae.

Telson (Figure 30F). (Damaged in the specimen) Subrectangular, distal margin bearing row of 13 min spines and 3 pairs of spines on lateral margin, small simple setae between the lateral spines.

$$
\begin{gathered}
\text { Family Penaeidae Rafinesque, } 1815 \\
\text { Genus Funchalia J. Y. Johnson, } 1868 \\
\text { Funchalia villosa (Bouvier, 1905) } \\
\text { (Figures } 31 \text { and 32) }
\end{gathered}
$$

Material examined: Gulf of Mexico: HBG 6776, R/V Point Sur, DP04-06Aug16-MOC10SW6N-059-N4, from 26.9936, -89.9941 to 27.0451, -90.0844, 6 August 2016, 601-4 m, MOCNESS plankton net, H. Bracken-Grissom, coll. Gulf of Mexico: HBG 6885, R/V Point Sur, DP04-06Aug16-MOC10-SW6D-058-N0, from 26.9942, -89, 9938 to 27.0611, -90.0923, 6 August 2017, 1510.6-NA m, MOCNESS plankton net, H. Bracken-Grissom, coll. Gulf of 
Mexico: HBG 7941, R/V Point Sur, DP05-08May17-MOC10-B081N-083-N0, from 28.5187, $-87,9897,8$ May 2017, 1500-0 m, MOCNESS plankton net, L. Timm, coll.

Juvenile. Size. $11 \mathrm{~mm}$ (Carapace length); $32 \mathrm{~mm}$ (Total length). $\mathrm{N}=3$.

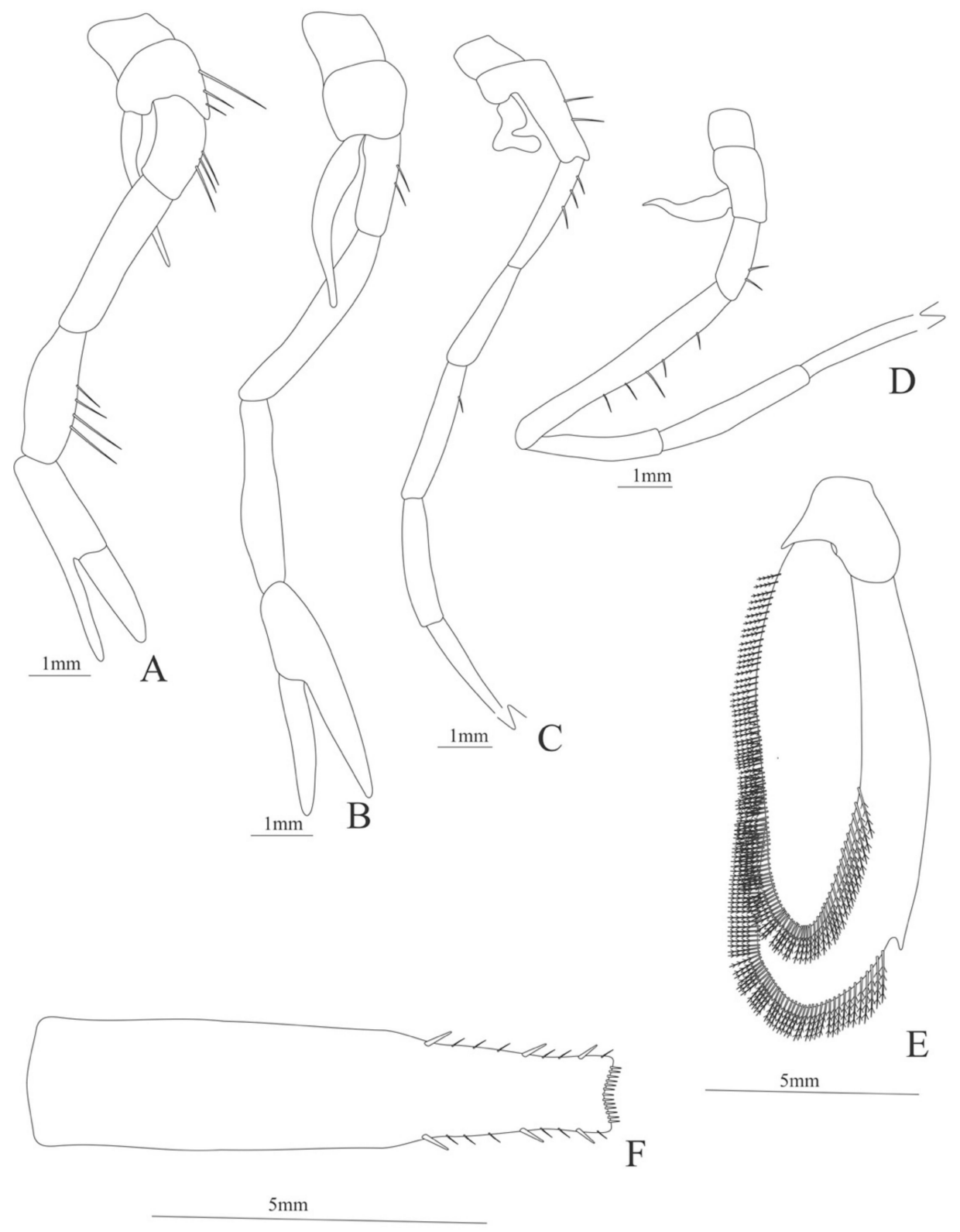

Figure 30. Cerataspis monstrosus: (A) second pereopod; (B) third pereopod; (C) fourth pereopod; (D) fifth pereopod; (E) uropods; (F) telson.

Carapace (Figure 31A) with rostrum short, armed with 5-7 dorsal spines, epigastric tooth present.

Pleon (Figure 31A) with 6 somites, without spines or setae. Pleopods 2 and 4 missing in the specimen, pleopods 1,3 and 5 well development.

Antennule (Figure 31B). Peduncle 3-segmented, article 1 the longest, slender, with 28 simple plus 6 plumose setae, article 2 with 24 simple setae and article 3 , the smallest with 10 simple setae and two flagella distally.

Antenna (Figure 31C). Protopod 3-segmented with a flagellum; exopod with 30-48 plumose setae.

Mandible (Figure 31D). Palp 2-segmented, articles 1armed with 3-8 simple setae and article 2 with $18-44$ plumose setae. 
Maxillule (Figure 31E): Coxal endite with 26-43 (12-22 serrulated plus 14-21 conical serrulated) setae; basial endite with 18 plumose setae setae.

Maxilla (Figure 31F). Coxal endite with one simple setae, basial endite bilobed with 6-12 + 8-16 simple setae; endopod with one simple setae, segmentation not well defined; scaphognathite margin with 65-126 plumose setae.

First maxilliped (Figure 31G). Coxa with 6 simple setae, basis with 14-26 simple setae; endopod unsegmented with 5 simple setae; exopod with 11-19 simple setae.

Second maxilliped (Figure $31 \mathrm{H})$. Coxa without setae, basis with 5-7 simple setae; endopod 4-segmented with 11-18, 0-3, 12-22 serrated, 6-16 serrated setae; exopod unsegmented and unarmed.

Third maxilliped (Figure 31I). Coxa and basis without setae, endopod 5-segmented with 7-10, 3-5, 11-16, 11-21, 9-21 simple setae; exopod with 8-34 setae.

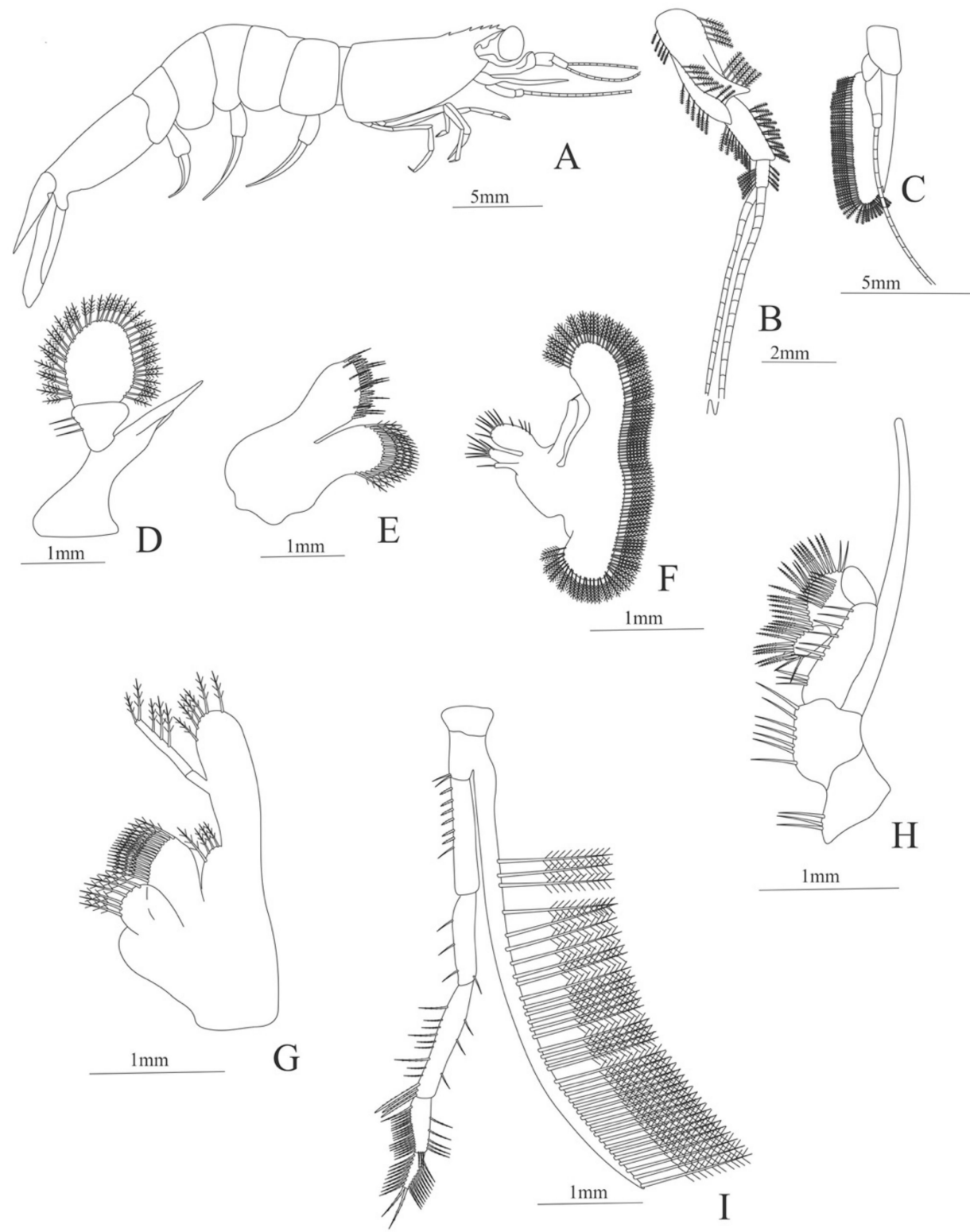

Figure 31. Funchalia villosa: (A) lateral view; (B) antennule; (C) antenna; (D) mandible; (E) maxillule; (F) maxilla; (G) first maxilliped; (H) second maxilliped; (I) third maxilliped.

First pereopod (Figure 32A). Coxa and basis with 2 setae; endopod 5-segmented with $4-5,4-8,7-15,6-11,3-7$ setae. 
Second pereopod (Figure 32B). Coxa and basis with 2 simple setae; endopod 5-segmented with 3-6, 9-20 (3-9 spines plus 6-11 simple), 8-21, 6-8, 4-5 simple setae.

Third pereopod (Figure 32C). Coxa with 2 simple setae, basis without setae; endopod 5-segmented with 4-14, 10-16, 7-14, 7-9, 1-7 simple setae.

Fourth pereopod (Figure 32D). Coxa with 2 simple setae, basis with one seta; endopod 5-segmented with 6-15, 16-39, 8-10, 12-21, 0 simple setae.

Fifth pereopod (Figure 32E). Coxa with 3-6 simple setae, basis with 2-4 setae; endopod 5-segmented with 5-14, 10-16, 3-13, 3-9, 0 simple setae.

Uropod (Figure 32F). Endopod well developed with 30-126 plumose setae; exopod with 54-143 plumose setae.

Telson (Figure 32G) enlarged, subtriangular, distal margin with a pointed projection, 3 pairs of spines near the distal margin, lateral margins with small simple setae.
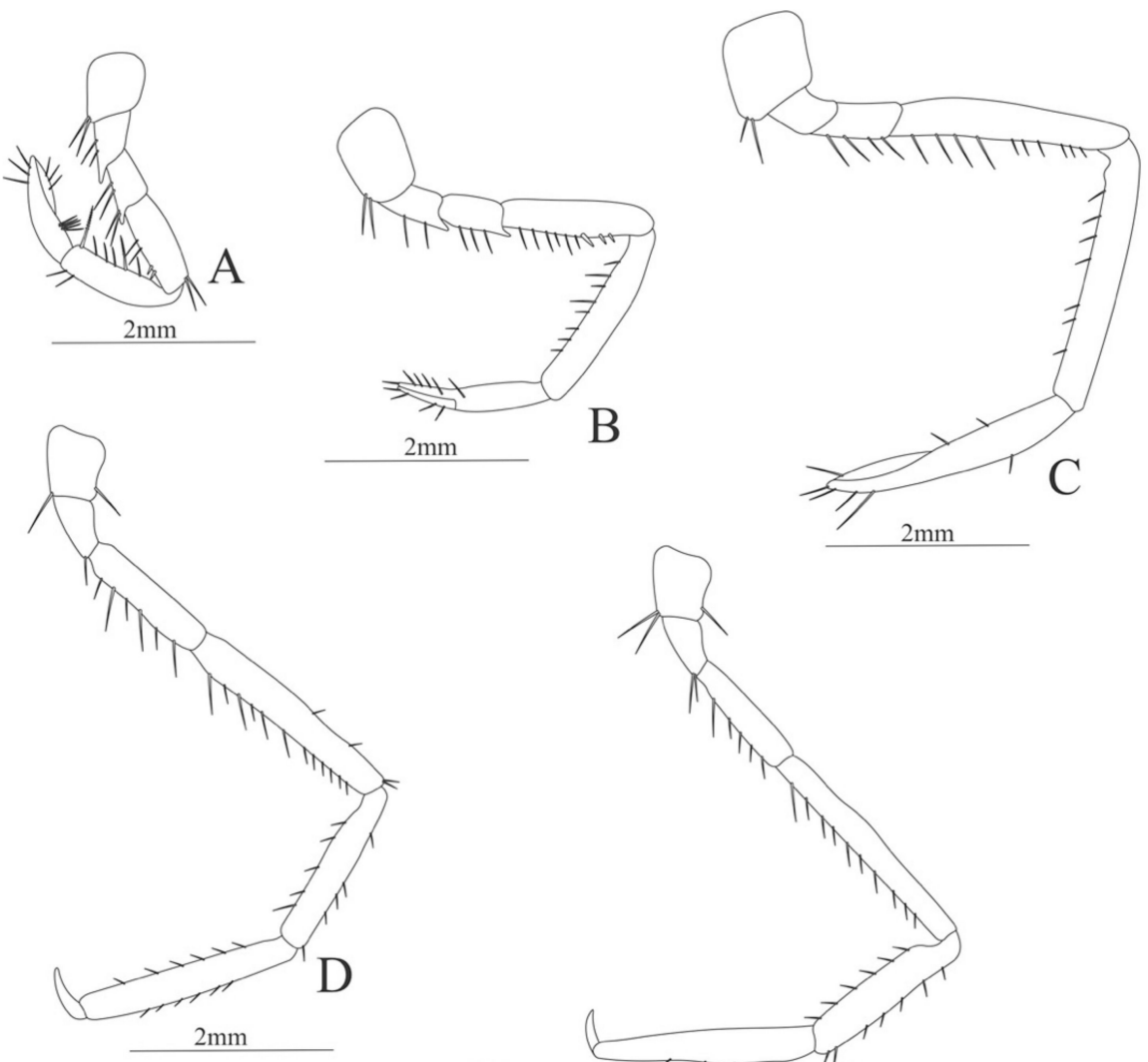

B
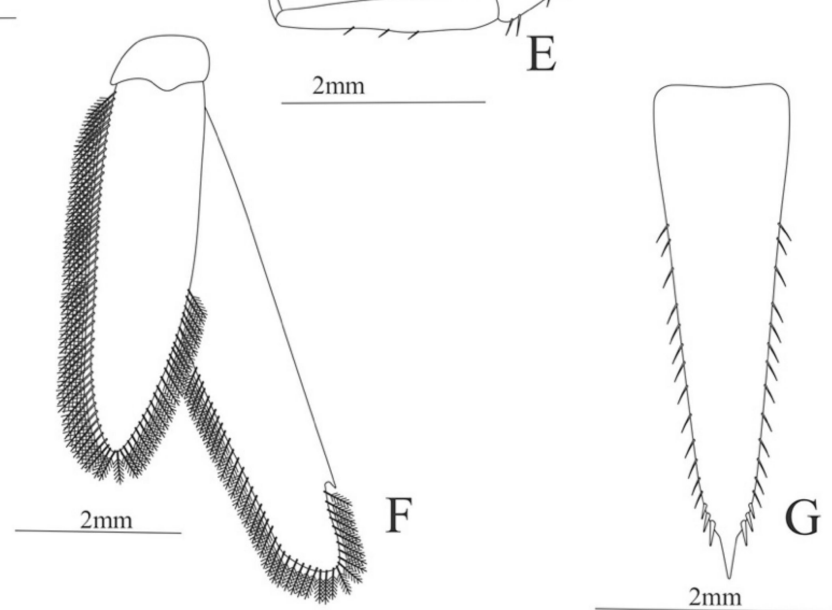

Figure 32. Funchalia villosa: (A) first pereopod; (B) second pereopod; (C) third pereopod; (D) fourth pereopod; (E) fifth pereopod; (F) uropods; (G) telson. 


\section{Discussion}

Here, we use DNA barcoding to successfully match 16 developmental stages and 14 larval and juvenile species with their adult counterpart. In the Section 3 we provide the phylogenetic evidence for the larval-adult identification accompanied by taxonomic descriptions and illustrations. Below, we summarize our main findings with a brief description of the current state of knowledge for deep-sea larval biology across each group. For many of these deep-sea shrimp species and some families, larval descriptions are scarce or non-existent.

It is important to note that many of these species likely have multiple larval stages and much more work is needed to fully describe the life history. Developmental plasticity in the number of larval stages is common for shrimps and several factors, including temperature, salinity and available food, can influence this variability [62-67]. These factors affect the molting cycle and can produce morphological differences across larvae stages [68]. Even at the population level, the same species can have a different number of larval stages and variation in the morphology (ex. the armature of thoracopods and pereopods $[6,69]$.

\subsection{Suborder Dendrobranchiata}

\subsubsection{Family Aristeidae}

The family Aristeidae contains nine genera, of which only 6 are present in the Gulf of Mexico [39,70]. The species in this family predominantly occupy deep-sea benthic habitats, although there are species that inhabit the meso- and bathypelagic zones, where they play an important role in the oceanic food web [71,72]. For almost 180 years, the larval stages of some genera within this family including Plesiopenaeus (=Cerataspis) and Aristaeomorpha Wood-Mason, 1891 were called "Cerataspis". These "cerataspis-like" individuals were so morphologically distinct and bizarre they were considered a valid genus and their affinity to other groups was unknown [73]. However, in 2012, Bracken-Grissom et al., used molecular techniques to unravel the mystery surrounding one larval form called Cerataspis montrosus, identifying the adult counterpart to be Plesiopenaeus armatus within the family Aristeidae. Larval stages of these deep-sea shrimp are frequently found in the stomach contents of fish and collected in nekton nets in shallow water and deep-sea waters. In the Gulf of Mexico, the mysis stage of Cerataspis monstrosus Gray, 1828 is the only record from this family [74] and the larval stages of Aristeus antennatus and Aristeomorpha foliacea have been previously recorded [75-78].

In the present study, two mysis stages of Hemipenaeus carpenteri and an additional mysis stage of Cerataspis monstrosus are illustrated. Identifications were made using sequences obtained by [74]. In the case of the two zoea stages of H. carpenteri, we have found that both stages morphologically resemble the mysis II and mysis III stages described by [48] for Cerataspis monstrosus. This finding verifies that it is typical for multiple species within the family Aristeidae to present these bizarre "cerataspis-like" pelagic larval stages. In the case of the zoea Cerataspis monstrosus, our material appears to be an undescribed mysis stage and could be a more advanced developmental stage that the ones described by [48] due to the reduction of the exopods in the $1-5$ pereopods. Nevertheless, more material is needed to confirm this result.

\subsubsection{Family Penaeidae}

The family Penaeidae consists of 27 genera, of which only eight are present in the Gulf of Mexico $[39,70]$. Many species within this family are considered valuable resources for fisheries and aquaculture, both in tropical and subtropical regions [79,80]. Many of the larval stages of species of commercial interest are known, such as the genera Penaeus Fabricius, 1798, Metapenaeopsis Bouvier, 1905, Rimapenaeus Perez-Farfante and Kensley, 1997 and Trachypenaeus Perez-Farfante, 1972, nevertheless, there are still problems in the identification of these larval stages [25,81-83].

In this paper, we have a juvenile Funchalia villosa which was identified using sequences obtained by [35]. This species is pelagic, and it is known to perform diel vertical migrations, 
descending to $2608 \mathrm{~m}$ deep during the day and migrating to shallow water of around $50 \mathrm{~m}$ deep at night $[84,85]$. Our material does not present exopods on the pereopods and resembles an adult specimen according to [86].

\subsection{Infraorder Caridea}

\subsubsection{Family Acanthephyridae}

The family Acanthephyridae consists of seven genera, with six genera present in the Gulf of Mexico: Acanthephyra, Heterogenys, Hymenodora, Ephyrina, Meningodora and Notostomus [39,70]. This family inhabits only deep waters and meso-bathypelagic habitats, and many perform daily vertical migrations [87-89]. Past studies examining the larval biology of this family within the Gulf of Mexico is lacking, however some work does exist for species of Acanthephyra [90-93]. Egg size across the family varies drastically and much work is still to be done [67]. Past studies have divided the family into two major groups based on developmental characertistics. Group one consists of the genera Ephyrina and Hymenodora which have large lipid-filled eggs and five or fewer zoeal stages, whereas group two includes the genera Acanthephyra, Meningodora and Notostomus which have small eggs and nine or more planktotrophic stages $[67,90]$.

In our study we identified one zoea stage of Meningodora longisulca and Ephyrina ombango, and one decapodite stage of $M$. vesca using sequences from [35]. In all cases, these are the first descriptions and illustrations of developmental stages belonging to these pelagic species. For Meningodora longisulca, the zoea is half the reported size for the adult and differs in several morphological characteristics. These include a zoea with (1) an unarmed rostrum in contrast to an armed adult rostrum with 7-10 dorsal spines, (2) the cornea wider than the peduncle in contrast to the adult cornea slightly narrowed than the eyestalk, and (3) underdeveloped mouthparts. For Meningodora vesca, the decapodite has characters very similar to those of the adult [87,94]. For Ephyrina ombango, the zoea differs from the adult in the shape of the rostrum. This includes the zoea possessing a blunt projection compared to the adult rostrum directed slightly anterodorsally [87-89].

\subsubsection{Family Alvinocarididae}

The family Alvinocarididae consists of 9 genera, but only the genus Alvinocaris is present in the Gulf of Mexico [39,70]. The members of this family are understudied and inhabit deep-sea cold seeps and hydrothermal vents areas around the world, with depths that vary from 250 to $4500 \mathrm{~m}$ [95-97]. This family is fraugth with taxonomic problems because larval stages have been erroneously described as new genera or species [98,99].

Across all alvinocaridids, only the morphology of the first zoea of four species is known including Alvinocaris muricola Williams, 1988, Mirocaris fortunata (Martin and Christiansen, 1995), Nautilocaris saintlaurentae Komai and Segonzac, 2004 and Rimicaris exoculata Williams and Rona, 1986 [98]. In this study we found a decapodite stage of Alvinocaris stactophila, and to identify this material, we used the sequences obtained by [99]. Our material is close to the adult size range; however, it still differs in some characteristics. This includes the shape of the decapodite carapace which is longer than wide, and the adult carapace is almost as long as wide. Differences also exist in mouthparts including the armature of the maxillipeds 2 and 3 lacking setae, which is a larval characteristic of this family. However, the remaining mouthparts such as the maxillula, maxilla and maxilliped 1 present an armature similar to that described for the adult [93,99]. As reported for several other species of alvinocaridids, the larval stages of Alvinocaris stactophila are pelagic $[100,101]$. This was confirmed with our material since the decapodite was captured using a MOCNESS trawl at depths of $600-1000 \mathrm{~m}$. The adult of this species is benthic, inhabiting cold seeps at a depth of $534 \mathrm{~m}$, making this a new depth record for this species. It is still unknown how the pelagic larval forms locate cold and hydrothermal seeps as they are presumably located $10 \mathrm{~s}$ to $100 \mathrm{~s}$ of meters from these ecosystems. 


\subsubsection{Family Eugonatonotidae}

The family Eugonatonotidae consists of only one genus, Eugonatonus Schmitt, 1926, which is present in the Gulf of Mexico [39,70]. The collection of this deep-sea species has been considered rare or very unusual [102,103]. The lack of knowledge surrounding the larval stages of the species has led to the description of Galatheacaris abyssalis and the creation of the family Galatheacarididae (=Eugonatonotidae) and the superfamily Galatheacaridoidea (=Nematocarcinoidea) [104]. This mistake was later corrected by [105] which found the new discovery to be a larval stage of Eugonatonotus chacei Chan and Wu, 1991.

Our material contains a zoea stage of Eugonatonotus crassus, which was identified using the sequences of [106]. De Grave et al., [105], states that this genus of benthic shrimp possibly has several planktonic zoeal stages. This is the first time that illustrations for the zoeal stage of Eugonatonotus crassus have been documented.

\subsubsection{Family Nematocarcinidae}

The family Nematocarcinidae consists of five genera, of which only two are present in the Gulf of Mexico [39,70]. The members of this family represent a wide bathyal distribution and can be found associated with the benthic community $[87,88,107]$. Illustrations of larval stages have only been recorded for very few species within the genus Nematocarcinus [65].

In the present study, the zoea and decapodite of N. rotundus and the zoea of N. cursor are illustrated. To identify this material, we used the sequences of [108] and sequences obtained from adult specimen material found in the Florida International Crustacean Collection (FICC) that were identified using $[88,107]$. It appears that both zoeal stages of N. rotundus and N. cursor are advanced based on size [65]. As for the decapodite of N. rotundus, the specimen shows characters similar to those of the adult. These include a short rostrum (with dorsal teeth) that does not exceed the article 2 of the antennule and a telson that does not exceed the uropods. This is the first time that illustrations of these developmental stages have been recorded for N. cursor and N. rotundus.

\subsubsection{Family Oplophoridae}

The family Oplophoridae consists of three genera, all of which are present in the Gulf of Mexico [39,70]. The members of this family, like those of the family Acanthephyridae, inhabit deep waters in meso-bathypelagic habitats and perform daily vertical migrations $[87,89]$. For this family, larval stage illustrations have only been reported for two species, Oplophorus spinosus and Systellaspis debilis $[67,90,91]$.

In this paper, information on the decapodite stage of Systellaspis braueri is provided for the first time and identifications were given using the sequences obtained by [35]. The complete larval development of $S$. debilis has four zoeal stages and one decapodite stage, which suggests that the species of this genus are lecithotrophic and have a short larval development with few stages. Lecithotrophy is considered an adaptation to the deep-sea environment where they live [67].

\subsubsection{Family Pandalidae}

The family Pandalidae consists of 19 genera, of which only three, Heterocarpus, Pantomus and Plesionika, are present in the Gulf of Mexico [39,70]. The representatives of this family are distributed world-wide, and many species inhabit deep waters [109]. In addition, due to their size, some species are of commercial interest [110-113]. The number of zoeal stages varies greatly among species within the family Pandalidae, where the complete life cycle of these species has been studied. For example, in the genus Pandalopsis (=Pandalus), the life cycle is completed in only 3-5 zoeal stages, while in the genus Pandalus Leach, 1814 (in Leach, 1813-1815), depending on the species, the life cycle is completed in 2-7 zoeal stages [114]. It is also known that species within the genus Plesionika have at least 7 to 8 zoeal stages [115].

In the present study, the juvenile stage of Plesionika ensis, decapodite stage of P. edwarsii and a zoea stage of Heterocarpus ensifer are presented. All material was identified using 
sequences obtained by $[35,116]$. Although the complete larval development of species belonging to the genus Plesionika are still unknown [114,115], past studies have reported the larval stages from seven species. This includes the following: the first zoeal stages for Plesionika acanthonotus (Smith, 1882), P. crosnieri Chan and Yu, 1991, P. ortmanni Doflein, 1902 and P. semilaevis Bate, 1888; the first to the seventh zoeal stages for P. edwardsii (Brandt, 1851); the first to the eighth zoeal stages for P. grandis Doflein, 1902; and the first five zoeal and the decapodite stages for P. narval (J. C. Fabricius, 1787) [10,46,116,117]. In the material presented here, the zoeal stages of the species in the genus Plesionika have the dorsal connection between carapace and abdomen at an almost $180^{\circ}$ angle, an eye peduncle narrowed at base, antennular peduncles strongly concave, a well-developed rostrum since the first stage and with dorsal spines in later stages, supraorbital spines present, and pereiopod 5 without an exopod [114]. The decapodite stages have a carapace with anterior and posterior dorsomedial tubercles, supraorbital spines present, a mandible without palp, the first four pereopods with exopods, and a carpus of pereiopod two not multi-articulated [114]. The material of Plesionika ensis represents a juvenile specimen, in which, the pereopods show reduction of the exopods, the mandibular palp is developed and the carpus of pereopod two is subdivided. Our material of P. edwarsii seems to be a decapodite stage due to the absence of the mandibular palp, the non-segmentation of the carpus in pereopod two, and the reduction in the pereopodal exopods. The reduction of exopods in the pereopods has also been recorded for the decapodite state of Plesionika narval [114].

Regarding Heterocarpus ensifer, only the first four zoeal stages of this species have been recorded [44]. Our material appears to be a more advanced zoea stage, presenting characters common to the zoea of the family Pandalidae, such as dorsal connection between carapace and abdomen at an almost 180-degree angle, the eye peduncle narrowed at base, well-developed rostrum, and supraorbital spines present. However, our material lacks a mandibular palp, subdivision of the carpus of pereopod two and has exopods on pereopods $1-4$. These findings support our hypothesis that our Heterocarpus material is from a more advanced zoea stage. Our material represents the first illustrations of a juvenile of $P$. ensis, a decapodite stage of P. edwardsii and a zoea of $H$. ensifer.

\section{Conclusions}

This study represents the benefits of using DNA barcoding to help advance the field of larval biodiversity. More specifically, these methods can be used as a complementary approach alongside taxonomy to assist in species identification. This is especially useful for species where the larval morphology differs significantly from the adult and those that are difficult to rear in the laboratory $[118,119]$. Together, molecular and morphological methods hold great promise in the conservation of marine biodiversity [120] and should be used to reveal the unseen, bizarre and mysterious world that exists in the deep sea.

Supplementary Materials: The following are available online at https://www.mdpi.com/article/10 $.3390 /$ d13100457/s1, Table S1. Taxonomy, voucher catalog numbers, localities and GenBank (GB) accession numbers for gene sequences used in the study. An "N/A" = not available. Gulf of Mexico $=$ GOM), Florida Straits = FL Straits, and Mediterranean = Mediterr, Figure S1. Maximum Likelihood (ML) phylogeny of 70 barcoded individuals from the suborder Dendrobranchiata and infraorder Caridea based on the mitochondrial 16S gene, Figure S2. Maximum Likelihood (ML) phylogeny of 43 barcoded individuals from the suborder Dendrobranchiata and infraorder Caridea based on the mitochondrial COI gene.

Author Contributions: C.V. and H.B.-G. have contributed to the conceptualization, methodology and writing of this work; C.V. contributed to the generation and analysis of the data and development of the figures; H.B.-G. contributed to securing funding for the work. Both authors have read and agreed to the published version of the manuscript.

Funding: This research was made possible by grants from The Gulf of Mexico Research Initiative (GOMRI), the National Science Foundation (NSF) Division of Environmental Biology Grant (\# 1556059 
awarded to H.B.-G.), the National Oceanic and Atmospheric Administration's (NOAA) RESTORE Science Program (\# NA19NOS4510193 to Florida International University and Nova Southeastern University) and the NOAA Ocean Exploration Research (NOAA-OER) Grant (\#NA170AR0110208; awarded to S. Johnsen).

Institutional Review Board Statement: Not applicable.

Data Availability Statement: Data are publicly available through the Gulf of Mexico Research Initiative Information and Data Cooperative (GRIIDC) at https://data.gulfresearchinitiative.org. https:/ / doi.org/10.7266/N70P0X3T and https:/ / doi.org/10.7266/n7-1xs7-4n30.

Acknowledgments: The authors thank all members of the Deep-Pelagic Nekton Dynamics of the Gulf of Mexico (DEEPEND) research consortium and the NSF Bioluminescence and Vision team for their assistance during the cruises. A special thanks to Danté Fenolio for the captivating images of crustacean larvae and plate assembly, the CRUSTOMICS lab for helping sort and curate samples, and the crew of the R/V Point Sur and University of Miami R/V Walton Smith for their assistance in collecting these specimens. We would also like to extend gratitude to PhD Candidate Carlos Varela's PhD committee: Ligia Collado-Vides, Elizabeth Anderson, Jose M. Eirin-Lopez and DeEtta Mills. This is contribution \#289 from the Coastlines and Oceans Division in the Institute of Environment at Florida International University.

Conflicts of Interest: The authors declare no conflict of interest. The funders had no role in the design of the study; in the collection, analyses, or interpretation of data; in the writing of the manuscript, or in the decision to publish the results.

\section{References}

1. Heppell, S.S.; Caswell, H.; Crowder, L.B. Life histories and elasticity patterns: Perturbation analysis for species with minimal demographic data. Ecology 2000, 81, 654-665. [CrossRef]

2. McGill, B.J.; Enquist, B.J.; Weiher, E.; Westoby, M. Rebuilding community ecology from functional traits. Trends Ecol. Evol. 2006, 21, 178-185. [CrossRef] [PubMed]

3. Williams, E.H.; Bunkley-Williams, L. Life Cycle and Life History Strategies of Parasitic Crustacea. In Parasitic Crustacea; Zoological Monographs; Smit, N., Bruce, N., Hadfield, K., Eds.; Springer: Cham, Switzerland, 2019; Volume 3, pp. 179-266.

4. Bondad-Reantaso, M.G.; Subasinghe, R.P.; Josupeit, H.; Cai, J.; Zhou, X. The role of crustacean fisheries and aquaculture in global food security: Past, present and future. J. Invertebr. Pathol. 2012, 110, 158-165. [CrossRef] [PubMed]

5. Wolfe, J.; Breinholt, J.; Crandall, K.; Lemmon, A.; Lemmon, E.; Timm, L.E.; Siddall, M.; Bracken-Grissom, H. A phylogenomic framework, evolutionary timeline, and genomic resources for comparative studies of decapod crustaceans. Proc. R. Soc. B 2019, 286, 20190079. [CrossRef] [PubMed]

6. Anger, K. The Biology of Decapod Crustacean Larvae; Crustacean Issues; A.A. Balkema Publishers: Amsterdam, The Netherlands, 2001; Volume 14, 419p.

7. Martin, J.W.; Olesen, J.; Hoeg, J.T. (Eds.) Introduction. In Atlas of Crustacean Larvae; John Hopkins University Press: Baltimore, MD, USA, 2014; pp. 1-7.

8. Matsuda, H.; Takenouchi, T.; Goldstein, J.S. The Complete Larval Development of the Pronghorn Spiny Lobster Panulirus penicillatus (Decapoda: Palinuridae) in Culture. J. Crustacean Biol. 2006, 26, 579-600. [CrossRef]

9. Goldstein, J.S.; Matsuda, H.; Takenouchi, T.; Butler, M.J. IV The Complete Development of Larval Caribbean Spiny Lobster Panulirus argus (Latreille, 1804) in Culture. J. Crustacean Biol. 2008, 28, 306-327. [CrossRef]

10. Jiang, G.C.; Chan, T.Y.; Shih, T.W. Larval development to the first eighth zoeal stages in the deep-sea caridean shrimp Plesionika grandis Doflein, 1902 (Crustacea, Decapoda, Pandalidae). Zookeys 2017, 719, 23-44. [CrossRef]

11. Sanvicente-Añorve, L.; Zavala-Hidalgo, J.; Allende-Arandía, E.; Hermoso-Salazar, M. Larval dispersal in three coral reef decapod species: Influence of larval duration on the metapopulation structure. PLoS ONE 2018, 13, e0193457. [CrossRef]

12. Harvey, A.W.; Martin, J.W.; Wetzer, R. Phylum Arthropods: Crustacea. In Atlas of Marine Invertebrate Larvae; Young, C.M., Sewell, M.A., Rice, M.E., Eds.; Academic Press: San Diego, CA, USA, 2002; pp. 337-370.

13. Torres, A.P.; dos Santos, A.; Alemany, F.; Massuti, E. Larval stages of crustacean species of interest for conservation and fishing exploitation in the western Mediterranean. Sci. Mar. 2013, 77, 149-160. [CrossRef]

14. Epifanio, C.E. Early Life History of the Blue Crab Callinectes sapidus: A Review. J. Shellfish Res. 2019, 38, 1-22.

15. Cook, H.L. A generic key to the protozoean, mysis and post-larval stages of the littoral penaeidae of the northwestern Gulf of Mexico. Fish Bull 1966, 65, 437-447.

16. Pérez-Farfante, I. Diagnostic Characters of Juveniles of the Shrimps Penaeus aztecus aztecus, P. duorarum duorarum, and P. brasiliensis (Crustacea; Decapoda; Penaeidae); Special Scientific Report; United States Fisheries Wildlife Service: Washington, DC, USA, 1970; Volume 559, pp. 1-26.

17. Subrahmanyam, C.B. Descriptions of Shrimp Larvae (Family Penaeidae) Off the Mississippi Coast. Gulf Res. Rep. 1971, 3, 241-258. [CrossRef] 
18. Porter, H.J. Zoeal stages of the stone crab, Menippe mercenaria Say. Chesap. Sci. 1960, 1, 168-177. [CrossRef]

19. Martin, J.W. Notes and bibliography on the larvae of xanthid crabs, with a key to the known xanthid zoeas of the western Atlantic and Gulf of Mexico. Bull. Mar. Sci. 1984, 34, 220-239.

20. Martin, J.W.; Truesdale, F.M.; Felder, D.L. Megalopa stage of the Gulf stone crab Menippe adina Williams and Felder, 1986 with a comparison in the megalopae in the genus Menippe. Fish Bull. 1988, 86, 289-297.

21. Stuck, K.; Perry, H.; Graham, D.; Heard, R.W. Morphological Characteristics of Early Life History Stages of the Blue Crab, Callinectes sapidus Rathbun, from the Northern Gulf of Mexico with a Comparison of Studies from the Atlantic Seaboard. Gulf Caribb. Res. 2009, 21, 37-55. [CrossRef]

22. Manzanilla-Dominguez, H.; Gasca, R. Distribution and Abundance of Phyllosoma Larvae (Decapoda, Palinuridae) in the Southern Gulf of Mexico and the Western Caribbean Sea. Crustaceana 2004, 77, 75-93.

23. Ditty, J.G.; Salas, J.A. Misidentification of mysis stages of Xiphopenaeus kroyeri (Heller, 1862) and Rimapenaeus Perez-Farfante and Kensley, 1997 (Decapoda: Penaeidae) in the Western Atlantic. J. Crustacean Biol. 2012, 32, 931-939. [CrossRef]

24. Cházaro-Olvera, S.; Winfield Aguilar, I.; Ortiz Touzet, M.; Vázquez-López, H.; Horta-Puga, G.J. Morphology of the Zoeae Larvae of Brachyura (Crustacea, Decapoda) in Veracruz, Southwestern Gulf of Mexico. Am. J. Life Sci. 2013, 1, 238-242. [CrossRef]

25. Criales, M.; Varela, C. Morphological Features of Taxonomical Value for the Identification of Three Western Atlantic Penaeid Shrimp Genera (Decapoda: Penaeidae). Gulf Caribb. Res. 2018, 29, 34-41. [CrossRef]

26. González-Gordillo, J.I.; dos Santos, A.; Rodríguez, A. Checklist and annotated bibliography of decapod Crustacea larvae from the Southwestern European coast (Gibraltar Strait area). Sci. Mar. 2001, 65, 275-305. [CrossRef]

27. Dos Santos, A.; Gonzalez-Gordillo, J.A. An illustrated key for the identification of zoeal stages of Pleocyemata larvae (Crustacea, Decapoda) from the southwestern European coast. J. Mar. Biol. Assoc. UK 2004, 84, 205-227. [CrossRef]

28. Vecchione, M. Importance of assessing taxonomic adequacy in determining fishing effects on marine biodiversity. ICES J. Mar. Sci. 2000, 57, 677-681. [CrossRef]

29. Vela, M.J.; González-Gordillo, J.I. Larval descriptions of the family Porcellanidae: A worldwide annotated compilation of the literature (Crustacea, Decapoda). ZooKeys 2016, 564, 47-70.

30. Savolainen, V.; Cowan, R.S.; Vogler, A.P.; Roderick, G.K.; Lane, R. Towards writing the encyclopedia of life: An introduction to DNA barcoding. Philos. Trans. R. Soc. Lond. 2005, B360, 1805-1811. [CrossRef]

31. Hebert, P.D.N.; Ratnasingham, S.; de Waard, J.R. Barcoding animal life: Cytochrome c oxidase subunit 1 divergences among closely related species. Proc. R. Soc. Lond. 2003, B270, S96-S99. [CrossRef]

32. Mantelatto, F.L.; Carvalho, F.L.; Simões, S.M.; Negri, M.; Souza-Carvalho, E.A.; Terossi, M. New primers for amplification of cytochrome c oxidase subunit I barcode region designed for species of Decapoda (Crustacea). Nauplius 2016, 24, e2016030. [CrossRef]

33. Mantelatto, F.L.; Terossi, M.; Negri, M.; Buranelli, R.C.; Robles, R.; Magalhães, T.; Tamburus, A.F.; Rossi, N.; Miyazaki, M.J. DNA sequence database as a tool to identify decapod crustaceans on the São Paulo coastline. Mitochondrial DNA Part A DNA Mapp. Seq. Anal. 2018, 29, 805-815. [CrossRef]

34. Terossi, M.; Almeida, A.O.; Buranelli, R.C.; Castilho, A.L.; Costa, R.C.; Zara, F.J.; Mantelatto, F.L. Checklist of decapods (Crustacea) from the coast of the São Paulo state (Brazil) supported by integrative molecular and morphological data: I. Infraorder Caridea: Families Hippolytidae, Lysmatidae, Ogyrididae, Processidae and Thoridae. Zootaxa 2018, 4370, 76-94. [CrossRef] [PubMed]

35. Varela, C.; Golightly, C.; Timm, L.E.; Wilkins, B.; Frank, T.; Fenolio, D.; Collins, S.B.; Bracken-Grissom, H.D. DNA barcoding enhances large-scale biodiversity initiatives for deep-pelagic crustaceans within the Gulf of Mexico and adjacent waters. J. Crustacean Biol. 2021, 41, ruab005. [CrossRef]

36. Gimenez, L. Phenotypic links in complex life cycles: Conclusions from studies with decapod crustaceans. Integr. Comp. Biol. 2006, 46, 615-622. [CrossRef]

37. Gattolliat, J.L.; Monaghan, M.T. DNA-based association of adults and larvae in Baetidae (Ephemeroptera) with the description of a new genus Adnoptilum in Madagascar. J. N. Am. Benthol. Soc. 2010, 29, 1042-1057. [CrossRef]

38. Walsh, H.J.; Richardson, D.E.; Marancik, K.E.; Hare, J.A. Long-Term Changes in the Distributions of Larval and Adult Fish in the Northeast U.S. Shelf Ecosystem. PLoS ONE 2015, 10, e0137382. [CrossRef]

39. Felder, D.L.; Álvarez, F.; Goy, J.W.; Lemaitre, R. Decapoda (Crustacea) of the Gulf of Mexico, with comments on the Amphionidacea. In Gulf of Mexico Origin, Water and Biota; Felder, D.L., Camp, D.K., Eds.; Texas A\&M University Press: College Station, TX, USA, 2009; Volume 1, pp. 1019-1104.

40. Villanueva, R. Decapod crab zoeae as food for rearing cephalopod paralarvae. Aquaculture 1994, 128, 143-152. [CrossRef]

41. Dunham, J.S.; Duffus, D.A. Diet of graywhales (Eschrichtius robustus) in Clayoquot Sound, British Columbia, Canada. Mar. Mammal Sci. 2002, 18, 419-437. [CrossRef]

42. Villanueva, R.; Perricone, V.; Fiorito, G. Cephalopods as Predators: A Short Journey among Behavioral Flexibilities, Adaptions, and Feeding Habits. Front. Physiol. 2017, 8, 598. [CrossRef]

43. Acevedo, J.; Aguayo-Lobo, A.; González, A.; Haro, D.; Olave, C.; Quezada, F.; Martínez, F.; Garthe, S.; Cáceres, B. Occurrence of Sei Whales (Balaenoptera borealis) in the Magellan Strait from 2004-2015, Chile. Aquat. Mamm. 2017, 43, 63-72. [CrossRef]

44. Landeira, J.M.; Lozano-Soldevilla, F.; Almansa, E.; Gonzalez-Gordillo, J.I. Early larval morphology of the armed nylon shrimp Heterocarpus ensifer ensifer A. Milne-Edwards, 1881 (Decapoda, Caridea, Pandalidae) from laboratory culture. Zootaxa 2010, 2427, 1-14. [CrossRef] 
45. Jiang, G.C.; Chan, T.Y.; Shih, T.W. Morphology of the first zoeal stage of three deep-water pandalid shrimps, Heterocarpus abulbus Yang, Chan \& Chu, 2010, H. hayashii Crosnier, 1988 and H. sibogae De Man, 1917 (Crustacea: Decapoda: Caridea). Zootaxa 2014, $3768,428-436$.

46. Landeira, J.M.; Lozano-Soldevilla, F.; González-Gordillo, J.I. Morphology of first seven larval stages of the striped soldier shrimp, Plesionika edwardsii (Brandt, 1851) (Crustacea: Decapoda: Pandalidae) from laboratory reared material. Zootaxa 2009, 1986, 51-66. [CrossRef]

47. Lindley, J.A.; Hernandez, F.; Scatllar, J.; Docoito, J. Funchalia sp. (Crustacea: Penaeidae) associated with Pyrosoma atlanticum (Thaliacea: Pyrosomidae) of the Canary Islands. J. Mar. Biol. Assoc. UK 2001, 81, 173-174. [CrossRef]

48. Heegard, P. Larvae of Decapod Crustacea: The Oceanic Penaeids Solenocera-Cerataspis-Cerataspides; Dana Report No. 67; Host Norway: Copenhagen, Denmark, 1966; pp. 1-147.

49. Cook, A.B.; Bernard, A.M.; Boswell, K.M.; Bracken-Grissom, H.; D’Elia, M.; de Rada, S.; English, D.; Eytan, R.I.; Frank, T.; Hu, C.; et al. A Multidisciplinary approach to investigate deep-pelagic eco- system dynamics in the Gulf of Mexico following Deepwater Horizon. Front. Mar. Sci. 2020, 7, 548880. [CrossRef]

50. Frank, T.; Widder, E. Comparative study of the spectral sensitivities of mesopelagic crustaceans. J. Comp. Physiol. A 1999, 185, 255-265. [CrossRef]

51. Martin, J.W.; Criales, M.M.; dos Santos, A. Dendrobranchiata. In Atlas of Crustacean Larvae; Martin, J.W., Olesen, J., Hoeg, J.T., Eds.; John Hopkins University Press: Baltimore, MD, USA, 2014; pp. 235-242.

52. Guerao, G.; Cuesta, J.A. Caridea. In Atlas of Crustacean Larvae; Martin, J.W., Olesen, J., Hoeg, J.T., Eds.; John Hopkins University Press: Baltimore, MD, USA, 2014; pp. 250-255.

53. Palumbi, S.; Martin, A.; Romano, S.; McMillan, W.; Stice, L.; Grabowski, G. The Simple Fool's Guide to PCR, version 2.0; University of Hawaii: Honolulu, HI, USA, 2002.

54. Crandall, K.A.; Fitzpatrick, J.F. Crayfish Molecular Systematics: Using a Combination of Procedures to Estimate Phylogeny. Syst. Biol. 1996, 45, 1-26. [CrossRef]

55. Simon, C.; Frati, F.; Beckenbach, A.; Crespi, B.; Liu, H.; Flook, P. Evolution, weighting and phylogenetic utility of mitochondrial gene sequences and a compilation of conserved polymerase chain reaction primers. Ann. Entomol. Soc. Am. 1994, 87, 651-701. [CrossRef]

56. Folmer, O.; Black, M.; Hoeh, W.; Lutz, R.; Vrijenhoek, R. DNA primers for amplification of mitochondrial Cytochrome C oxidase subunit I from diverse metazoan invertebrates. Mol. Mar. Biol. Biotechnol. 1994, 3, 294-299.

57. Katoh, K.; Misawa, K.; Kuma, K.; Miyata, T. MAFFT: A novel method for rapid multiple sequence alignment based on fast Fourier transform. Nucleic Acids Res. 2002, 30, 3059-3066. [CrossRef]

58. Kalyaanamoorthy, S.; Minh, B.Q.; Wong, T.K.F.; von Haeseler, A.; Jermiin, L.S. ModelFinder: Fast model selection for accurate phylogenetics estimates. Nat. Methods 2017, 14, 587-589. [CrossRef]

59. Nguyen, L.T.; von Schmidt, H.A.; Haeseler, A.; Minh, B.Q. IQ-TREE: A fast and effective stochastic algorithm for estimating maximum-likelihood phylogenies. Mol. Biol. Evol. 2015, 32, 268-274. [CrossRef]

60. Minh, B.Q.; Nguyen, M.A.T.; von Haeseler, A. Ultrafast approximation for phylogenetic bootstrap. Mol. Biol. Evol. 2013, 30, 1188-1195. [CrossRef]

61. Huelsenbeck, J.P.; Ronquist, F. MRBAYES: Bayesian inference of phylogenetic trees. Bioinformatics 2001, 17, 745-755. [CrossRef] [PubMed]

62. Thatje, S.; Schnack-Schiel, S.; Arntz, W.E. Developmental trade- offs in Subantarctic meroplankton communities and the enigma of low decapod diversity in high southern latitudes. Mar. Ecol. Prog. Ser. 2003, 260, 195-207. [CrossRef]

63. Thatje, S.; Lovrich, G.A.; Torres, G.; Hagen, W.; Anger, K. Changes in biomass, lipid, fatty acid and elemental composition during abbreviated larval development of the Subantarctic shrimp Campylonotus vagans. J. Exp. Mar. Biol. Ecol. 2004, 301, 159-174. [CrossRef]

64. Thatje, S.; Lovrich, G.A.; Anger, K. Egg production, hatching rates, and abbreviated larval development of Campylonotus vagans Bate, 1888 (Crustacea: Decapoda: Caridea) in Subant- arctic waters. J. Exp. Mar. Biol. Ecol. 2004, 301, 15-27. [CrossRef]

65. Thatje, S.; Bacardit, R.; Arntz, W.E. Larvae of the deep-sea Nematocarcinidae (Crustacea: Decapoda: Caridea) from the Southern Ocean. Polar Biol. 2005, 28, 290-302. [CrossRef]

66. Oliphant, A.; Hauton, C.; Thatje, S. The implications of temperature-mediated plasticity in larval instar number for development within a marine invertebrate, the shrimp Palaemonetes varians. PLoS ONE 2013, 8, e75785. [CrossRef]

67. Bartilotti, C.; dos Santos, A. The secret life of deep sea shrimps: Ecological and evolutionary clues from the larval description of Systellaspis debilis (Caridea: Oplophoridae). PeerJ 2019, 7, e7334. [CrossRef]

68. Wehrtmann, I.; Albornoz, L. Larvae of Nauticaris magellanica (Decapoda: Caridea: Hippolytidae) reared in the laboratory differ morphologically from those in nature. J. Marine Biol. Assoc. UK 2003, 83, 949-957. [CrossRef]

69. Thatje, S.; Bacardit, R. Morphological variability in larval stages of Nauticaris magellanica (A. Milne Edwards, 1891) (Decapoda: Caridea: Hippolytidae) from South American waters. Bull. Mar. Sci. 2000, 66, 375-398.

70. WoRMS Editorial Board World Register of Marine Species. 2021. Available online: https:/ /www.marinespecies.org (accessed on 13 August 2021). 
71. Pérez Farfante, I.; Kensley, B. Penaeoid and sergestoid shrimps and prawns of the world. Keys and Diagnoses for the Families and Genera; Mémoires du Muséum National d'Histoire Naturelle; Muséum National d'Histoire Naturelle: Paris, France, 1997; Volume 175, pp. 1-233.

72. Tavares, C.R.; Serejo, C.S. Taxonomy of Aristeidae (Dendrobranchiata: Penaeoidea) from the central coast of Brazil, collected by the Revizee program, between $19^{\circ}$ and $22^{\circ} \mathrm{S}$. Zootaxa 2007, 1585, 1-44. [CrossRef]

73. Franks, J.S.; Russell, A.D. First record of Cerataspis, a larval oceanic penaeoid crustacean, from the Gulf of Mexico. Gulf Caribb. Res. 2008, 20, 87-89. [CrossRef]

74. Bracken-Grissom, H.D.; Felder, D.L.; Vollmer, N.L.; Martin, J.W.; Crandall, K.A. Phylogenetics links monster larva to deep-sea shrimp. Ecol. Evol. 2012, 2, 2367-2373. [CrossRef] [PubMed]

75. Heldt, J.H. Contribution al etude de la biologie des crevettes peneides Aristeomorpha foliacea (Risso) et Aristeus antennatus (Risso) (formes larvaires). Bull. Société Des. Sci. Nat. Tunis. 1955, VIII, 1-29.

76. Carbonell, A.; dos Santos, A.; Alemany, F.; Vélez-Belchi, P. Larvae of the red shrimp Aristeus antennatus (Decapoda: Dendrobranchiata: Aristeidae) in the Balearic Sea: New occurrences fifty years later. Mar. Biodivers. Rec. 2010, 3, e103. [CrossRef]

77. Carreton, M.; Company, J.B.; Planella, L.; Heras, S.; García-Marín, J.L.; Agulló, M.; Clavel-Henry, M.; Rotllant, G.; dos Santos, A.; Roldán, M.I. Morphological identification and molecular confirmation of the deep sea blue and red shrimp Aristeus antennatus larvae. PeerJ 2019, 7, e6063. [CrossRef] [PubMed]

78. Carreton, M.; dos Santos, A.; de Sousa, L.F.; Rotllant, G.; Compan, J.B. Morphological description of the first protozoeal stage of the deep-sea shrimps Aristeus antennatus and Gennadas elegans, with a key. Sci. Rep. 2020, 10, 11178. [CrossRef] [PubMed]

79. Calo-Mata, P.; Pascoal, A.; Fernández-No, I.; Böhme, K.; Gallardo, J.M.; Barros-Velázquez, J. Evaluation of a novel 16S rRNA/tRNA ${ }^{\mathrm{Val}}$ mitochondrial marker for the identification and phylogenetic analysis of shrimp species belonging to the superfamily Penaeoidea. Anal. Biochem. 2009, 391, 127-134. [CrossRef]

80. Gusmão, J.; Lazoski, C.; Solé-Cava, A. A new species of Penaeus (Crustacea: Penaeidae) revealed by allozyme and cytochrome oxidase I analyses. Mar. Biol. 2000, 137, 435-446. [CrossRef]

81. Ditty, J.G. Young of Litopenaeus setiferus, Farfantepenaeus aztecus and F. duorarum (Decapoda: Penaeidae): A re-assessment of characters for species discrimination and their variability. J. Crustacean Biol. 2011, 31, 458-467. [CrossRef]

82. Ditty, J.G. Sternal Spines in Penaeid Postlarvae (Decapoda: Penaeidae): Life-Phase-Specific and Systematically Significant? J. Crustacean Biol. 2014, 34, 618-628. [CrossRef]

83. Ditty, J.G.; Alvarado-Bremer, J.R. Species discrimination of postlarvae and early juvenile brown shrimp (Farfantepenaeus aztecus) and pink shrimp (F. duorarum) (Decapoda: Penaeidae): Coupling molecular genetics and comparative morphology to identify early life stages. J. Crustacean Biol. 2011, 31, 126-137. [CrossRef]

84. Crosnier, A. Crevettes pénéides d'eau profonde récoltés dans l'océan Indien lors des campagnes Benthedi, Safari I et II, MD 32/Réunion. Bulletin du Muséum National d'Histoire Naturelle Sér. 4 Section A 1985, 9, 695-726.

85. González, J.A.; Santana, J.I. The family Penaeidae from the Canary Islands (Norteastern Atlantic), with first record of Penaeus kerathurus. Boletim Museu de Historia Natural do Funchal 2014, LXIV, 29-34.

86. De Freitas, A.J. The Penaeoidea of southeast Africa. II-The Family Penaeidae (excluding genus Penaeus). Investig. Rep. Oceanogr. Res. Inst. 1984, 58, 1-104.

87. Chace, F.A., Jr. Plankton of the Bermuda Oceanographic Expeditions. IX. The bathypelagic caridean Crustacea. Zoologica 1940, 25, 117-209.

88. Crosnier, A.; Forest, J. Les crevettes profondes de l'Atlantique Oriental Tropical. Faune Trop. 1973, 19, 1-409.

89. Alves, F.A., Jr.; dos Santos Silva, E.; Araujo, M.S.L.C.; Cardoso, I.; Bertrand, A.; Souza-Filho, J.F. Taxonomy of deep-sea shrimps of the Superfamily Oplophoroidea Dana 1852 (Decapoda: Caridea) from Southwestern Atlantic. Zootaxa 2019, 4613, 401-442. [CrossRef]

90. Gurney, R.; Lebour, M.V. On the larvae of certain Crustacea Macrura, mainly from Bermuda. J. Linn. Soc. Zool. 1941, 41, 89-181. [CrossRef]

91. Gurney, R. Larvae of decapod crustacea. Ray Soc. Lond. 1942, 129, 1-306.

92. Foxton, P. Observations on the Early Development and Hatching of the Eggs of Acanthephyra purpurea A. Milne-Edwards. Crustaceana 1964, 6, 235-237. [CrossRef]

93. Fernandes, L.D.A.; De Souza, M.F.; Bonecker, S.L.C. Morphology of Oplophorid and Bresiliid larvae (Crustacea, Decapoda) of Southwestern Atlantic plankton, Brazil. Pan-Am. J. Aquat. Sci. 2007, 2, 199-230.

94. Cardoso, I.A. New record of Meningodora vesca (Smith, 1887) (Caridea, Oplophoridae) to the Southwestern Atlantic. Nauplius 2006, 14, 1-7.

95. Williams, A.B. New marine decapod crustaceans from waters influenced by hydrothermal discharge, brine, and hydrocarbon seepage. Fish Bull. 1988, 86, 263-287.

96. Martin, J.W.; Haney, T. Decapod crustaceans from hydrothermal vents and cold seeps: A review through 2005. Zool. J. Linn. Soc. 2005, 145, 445-522. [CrossRef]

97. Vereshchaka, A.L.; Kulagin, D.N.; Lunina, A.A. Phylogeny and New Classification of Hydrothermal Vent and Seep Shrimps of the Family Alvinocarididae (Decapoda). PLoS ONE 2015, 10, e0129975. [CrossRef] 
98. Hernández-Ávila, I.; Cambon-Bonavita, M.A.; Pradillon, F. Morphology of First Zoeal Stage of Four Genera of Alvinocaridid Shrimps from Hydrothermal Vents and Cold Seeps: Implications for Ecology, Larval Biology and Phylogeny. PLoS ONE 2015, 10, e0144657. [CrossRef] [PubMed]

99. Shank, T.M.; Black, M.B.; Halanych, K.M.; Lutz, R.A.; Vrijenhoek, R.C. Miocene radiation of deep-sea hydrothermal vent shrimp (Caridea: Bresiliidae): Evidence from mitochondrial cytochrome oxidase subunit I. Mol. Phylogenetics Evol. 1999, 13, $244-254$. [CrossRef] [PubMed]

100. Vereshchaka, A.L. A new genus and species of caridean shrimp (Crustacea: Decapoda: Alvinocarididae) from Nort Atlantic hydrothermal vents. J. Mar. Biol. Assoc. UK 1996, 76, 951-961. [CrossRef]

101. Herring, P.; Gaten, E.; Shelton, P. Are vent shrimps blinded by science? Nature 1999, 398, 116. [CrossRef]

102. Chan, T.Y.; Yu, H.P. An uncommon deep-sea shrimp Eugonatonotus crassus (A. Milne Edwards, 1881) (Crustacea: Decapoda: Eugonatonotidae) from Taiwan. Bull. Inst. Zool. Acad. Sin. 1988, 7, 259-263.

103. Chan, T.Y.; Yu, H.P. Eugonatonotus chacei sp. nov., second species of the genus (Crustacea, Decapoda, Eugonatonotidae). Bulletin du Museum National d'Histoire Naturelle 1991, 13, 143-152.

104. Vereshchaka, A.L. New family and superfamily for a deep-sea caridean shrimp from the Galathea collections. J. Crustacean Biol. 1997, 17, 361-373. [CrossRef]

105. De Grave, S.; Chu, K.H.; Chan, T.Y. On the systematic position of Galatheacaris abyssalis (Decapoda: Galatheacaridoidea). J. Crustacean Biol. 2010, 30, 521-527. [CrossRef]

106. Aznar-Cormano, L.; Brisset, J.; Chan, T.Y.; Corbari, L.; Puillandre, N.; Utge, J.; Zbinden, M.; Zuccon, D.; Samadi, S. An improved taxonomic sampling is a necessary but not sufficient condition for resolving inter-families relationships in Caridean decapods. Genetica 2015, 143, 195-205. [CrossRef]

107. Burukovsky, R.N. Taxonomy of Nematocarcinus (Decapoda, Nematocarcinidae). Description of Nematocarcinus from waters of the American continent. Zool. Zhurnal 2001, 80, 1429-1443.

108. Wong, J.M.; Pérez-Moreno, J.L.; Chan, T.Y.; Frank, T.M.; Bracken-Grissom, H.D. Phylogenetic and transcriptomic analyses reveal the evolution of bioluminescence and light detection in marine deep-sea shrimps of the family Oplophoridae (Crustacea: Decapoda). Mol. Phylogenetics Evol. 2015, 83, 278-292. [CrossRef] [PubMed]

109. González, J.A.; Santana, J.I. Shrimps of the family Pandalidae (Crustacea, Decapoda) off the Canary Islands, Eastern Central Atlantic. S. Afr. J. Mar. Sci. 1996, 17, 173-182. [CrossRef]

110. Holthuis, L.B. FAO species catalogue. I. Shrimps and prawns of the world. An annotated catalogue of species of interest to fisheries. FAO Fish. Synop. 1980, 125, 271.

111. Holthuis, L.B. Crevelles. In Guide FAO d'Identification des Especes pour les Besoins de la Peche. (Revision I). Mediterranee et Mer Noire. Zone de Pêche 37. Vegetaux et Invertebres; Fischer, W., Bauchot, M.L., Schneider, M., Eds.; FAO: Rome, Italy, 1987; Volume 1, pp. 189-292.

112. Chilari, A.; Thessalou-Legaki, M.; Petrakis, G. Population structure and reproduction of the deep-water shrimp Plesionika martia (Decapoda: Pandalidae) from the eastern Ionian Sea. J. Crustacean Biol. 2005, 25, 233-241. [CrossRef]

113. Chakraborty, R.D.; Chan, T.Y.; Maheswarudu, G.; Kuberan, G.; Purushothaman, P.; Chang, S.C.; Jomon, S. On Plesionika quasigrandis Chace, 1985 (Decapoda, Caridea, Pandalidae) from southwestern India. Crustaceana 2015, 88, 923-930. [CrossRef]

114. Landeira, J.M.; Chan, T.Y.; Aguilar-Soto, N.; Jiang, G.C.; Yang, C.H. Description of the decapodid stage of Plesionika narval (Fabricius, 1787) (Decapoda: Caridea: Pandalidae) identified by DNA barcoding. J. Crustacean Biol. 2014, 34, 377-387. [CrossRef]

115. Landeira, J.M.; Gonzalez-Gordillo, J.I. Description of first five larval stages of Plesionika narval (Fabricius, 1787) (Crustacea, Decapoda, Pandalidae) obtained under laboratory conditions. Zootaxa 2009, 2206, 45-61. [CrossRef]

116. Matzen da Silva, J.; Creer, S.; dos Santos, A.; Costa, A.C.; Cunha, M.R.; Costa, F.O.; Carvalho, G.R. Systematic and Evolutionary Insights Derived from mtDNA COI Barcode Diversity in the Decapoda (Crustacea: Malacostraca). PLoS ONE 2011, 6, e19449. [CrossRef] [PubMed]

117. Jiang, G.C.; Landeira, J.M.; Shih, T.W.; Chan, T.Y. First zoeal stage of Plesionika crosnieri Chan \& Yu, 1991, P. ortmanni Doflein, 1902, and P. semilaevis Bate, 1888, with remarks on the early larvae of Plesionika Bate, 1888 (Crustacea, Decapoda). Zootaxa 2018, 4532, 385-395.

118. DeSalle, R. Species discovery versus species identification in DNA barcoding efforts: Response to Rubinoff. Conserv. Biol. 2006, 20, 154-1547. [CrossRef] [PubMed]

119. Landschoff, J.; Gouws, G. DNA barcoding as a tool to facilitate the taxonomy of hermit crabs (Decapoda: Anomura: Paguroidea). J. Crustacean Biol. 2018, 38, 780-793. [CrossRef]

120. Trivedi, S.; Aloufi, A.A.; Ansari, A.A.; Ghosh, S.K. Role of DNA barcoding in marine biodiversity assessment and conservation: An update. Saudi J. Biol. Sci. 2016, 23, 161-171. [CrossRef] 